\title{
Studying the Exclusionary Rule in Search and Seizure
}

\author{
Dallin H. Oaks†
}

The exclusionary rule makes evidence inadmissible in court if law enforcement officers obtained it by means forbidden by the Constitu. tion, by statute or by court rules. The United States Supreme Court currently enforces an exclusionary rule in state and federal criminal proceedings as to four major types of violations: searches and seizures that violate the fourth amendment, confessions obtained in violation of the fifth and sixth amendments, identification testimony obtained in violation of these amendments, and evidence obtained by methods so shocking that its use would violate the due process clause. ${ }^{1}$ The exclusionary rule is the Supreme Court's sole technique for enforcing

$\dagger$ Professor of Law, The University of Chicago; Executive Director-Designate, The American Bar Foundation.

This study was financed by a three-month grant from the National Institute of Law Enforcement and Criminal Justice of the Law Enforcement Assistance Administration of the United States Department of Justice. The fact that the National Institute furnished financial support to this study does not necessarily indicate the concurrence of the Institute in the statements or conclusions in this article.

Many individuals assisted the author in this study. Colleagues Hans Zeisel and Franklin Zimring gave valuable guidance on analysis, methodology and presentation. Colleagues Walter J. Blum, Gerhard Casper, Kenneth Dam, Aaron Director, Harry Kalven, Jr., Edmund W. Kitch, Norval Morris, Phil C. Neal, and Richard A. Posner furnished helpful ideas, principally during a February, 1970 discussion of this topic in the Law School's Workshop on Empirical Research. Third-year students Ralph/M. Faust, Jr., Joseph $H$. Groberg, and James $O$. Reyer gave expert research assistance throughout the project. Henry Ruth and Paul Nejelski of the Law Enforcement Assistance Administration made valuable suggestions, as did Professor Albert W. Alschuler of the University of Texas Law School. The author also conferred with and received indispensable information from police officials and prosecutors in Chicago, Cincinnati, Cleveland, Philadelphia, Toronto, and Washington, D.C. For reasons of confidentiality some of these law enforcement personnel must remain anonymous so none is identified here by name.

1 Mapp v. Ohio, 367 U.S. 643 (1961) (search and seizure); Miranda v. Arizona, 384 U.S. 486 (1966) (confessions); United States v. Wade, 388 U.S. 218 (1967) (lineups); Gilbert v. California, 388 U.S. 263 (1967) (identifications); Rochin v. California, 342 U.S. 165 (1952) ("shocking" methods). See generally T. AbBott, J. Cratsley, S. EnGelberG, D. Grove, P. Manahan \& B. Saypor, Law and Tagtics in Exclusionary Hearings 12-23 (1969).

The exclusionary rule is also applied in respect to wiretapping evidence obtained or proposed to be used in violation of federal law. 47 U.S.C. $\S 605$ (1964); Lee v. Florida, 392 U.S. 378 (1968). Under the Federal Rules of Criminal Procedure, applicable only in federal courts, the exclusionary rule prevents the use of confessions obtained during a period of detention in excess of the Rule 5(a) requirement of prompt presentment before 
these vital constitutional rights. As such, its importance in relation to these rights is comparable to the importance of incarceration in the enforcement of the substantive criminal law. At a time when there are resounding calls to reconsider the content and administration of penal sanctions in the substantive criminal law, it is also timely to reexamine the exclusionary sanction applied to related procedural rights.

This study concerns the effect of the exclusionary rule on the criminal justice system, particularly on law enforcement personnel. The subject is limited to the area of search and seizure. In addition to being the most frequent occasion for application of the exclusionary rule, search and seizure has two qualities that set it apart from other areas and make it appropriate for separate study. Evidence obtained by an illegal search and seizure is just as reliable as evidence obtained by legal means. This cannot always be said of evidence obtained by improper methods of lineup identification or interrogation. And, for reasons that will be discussed later, ${ }^{2}$ the exclusion of evidence obtained by an improper search and seizure is less likely to influence law enforcement behavior than is the exclusion of evidence obtained by improper means of identification or interrogation.

This article will report the state of existing knowledge and discuss possibilities for further empirical research. It has six parts.

Part I concerns the history and suggested justifications of the exclusionary rule. The normative justification-that courts should not participate in illegal behavior by using the evidence obtained by ithas not been important in determining the outcome of cases. The Supreme Court has stated that the "single and distinct" purpose of the exclusionary rule is to deter law enforcement officers from the forbidden behavior.

Part II reviews what Supreme Court Justices and prominent scholars have said about the deterrent effect of the exclusionary rule. Most have hailed it as the best available enforcement technique. Some have even stated that "experience has taught" that it is effective. But none has cited any substantial evidence that the rule effectively deters improper law enforcement behavior.

a magistrate. Mallory v. United States, 354 U.S. 449 (1957). Federal courts must also exclude evidence obtained by a violation of the law requiring an officer to give notice of his authority and purpose before opening a door to make an arrest or execute a warrant in a private dwelling. 18 U.S.C. § 3109 (1964); Miller v. United States, 357 U.S. 301 (1958). T. Аввотт, et al., supra. However, the announcement requirement was practically eliminated in the District of Columbia Court Reform and Criminal Procedure Act of 1970, 84 Stat. 473 (1970).

2 See text following note 160 infra. 
Part III presents empirical evidence on the effect of the exclusionary rule on police searches and seizures. Some of this evidence has been published previously, and some is new. Illegal searches and seizures seem to be concentrated in a few types of crimes, notably weapons and narcotics offenses. The data contains little support for the proposition that the exclusionary rule discourages illegal searches and seizures, but it falls short of establishing that it does not.

Part IV reviews the various aspects of deterrence, applies them to the exclusionary rule, and discusses possible techniques and areas for further research. No single research method can deal with the enormous complexities involved in attempting to measure the extent to which law enforcement behavior is affected by the exclusionary rule. It is suggested that the effect of the rule be studied in smaller segments by determining what the rule does not accomplish and by examining some of the negative effects that its use may entail. The last two parts concern those questions.

Part V discusses limitations upon the deterrent effectiveness of the exclusionary rule in certain circumstances. These limitations include the rule's probable inability to deter the large area of police conduct that is not intended to obtain evidence, for use in prosecution, and the fact that the exclusionary rule operates under numerous conditions that are unfavorable for deterring the police. The discussion suggests empirical research to test the factual assumptions underlying some of these limitations.

Part VI discusses various asserted negative effects of the exclusionary rule, such as the assertion that it fosters false testimony by law enforcement personnel or that it seriously delays and overloads a criminal proceeding and diverts attention from the search for truth on the guilt or innocence of the defendant. With respect to some of the alleged negative effects, the discussion contains suggestions for empirical research to test the critical facts.

The article concludes with a polemic argument for abolishing the exclusionary rule as to evidence obtained by searches and seizures, and replacing it with a practical tort remedy against the offending officers or their employers.

\section{History and Basis of Exclusionary Rule}

Limited to headlines, the history of the exclusionary rule pertaining to searches and seizures can be told in four cases. ${ }^{3} \mathrm{~A}$ dicțum in Boyd $v$.

8 Allen, Federalism and the Fourth Amendment: A Requiem for Wolf, 1961 Sur. Cr. REv. I; Broeder, The Decline and Fall of Wolf v. Colorado, 41 NEB. L. REv. 185 (1961). 
United States ${ }^{4}$ suggested for the first time that evidence obtained in violation of the fourth amendment should be inadmissible in court. After being ignored for thirty years, that suggestion became law in the federal courts in 1914 in Weeks v. United States. ${ }^{5}$ In 1949 the fourth amendment right to immunity from unreasonable search and seizure was recognized as applicable to state as well as to federal action in Wolf v. Colorado, ${ }^{6}$ but the Court declined to impose the exclusionary rule as a required method of enforcement. Finally, in Mapp $v$. Ohio, ${ }^{7}$ decided in 1961, the Court imposed the exclusionary rule on the states, holding that the failure to exclude evidence that state officers had obtained by an unreasonable search and seizure violated the defendant's rights under the due process clause of the fourteenth amendment.

Two types of justifications have been urged for the exclusionary rule, one normative and one factual. The normative justification is the evil of government participation in illegal conduct. The factual justification lies in the assertion that excluding evidence will reduce violations of the search and seizure rules. This result is supposed to follow in the short term from deterrence and in the long term from education. The exclusion of evidence obtained by an illegal search or seizure is expected to have the relatively immediate effect of deterring law enforcement officials from such improper behavior. In addition, by stressing the seriousness of society's commitment to observing the search and seizure rules, the exclusionary rule is expected to invoke the moral and educative force of the law and thus to have the long term effect of encouraging greater conformity.

The normative reasons concern the impropriety of the lawgiver's forbidding conduct on the one hand and at the same time participating in the forbidden conduct by acquiring and using the resulting evidence. ${ }^{8}$ Justices Brandeis and Holmes gave the leading expressions of this view in arguing for the exclusion of illegally obtained wiretap evidence in their notable dissents in Olmstead $v$. United States. ${ }^{9}$ Justice Holmes declared that he could attach no importance to the Government's expression of disapproval if it knowingly accepted and paid

4116 U.S. 616 (1886).

5232 U.S. 383 (1914).

6338 U.S. 25 (1949).

7367 U.S. 643 (1961).

8 "To sanction such proceedings would be to affirm by judicial decision a manifest neglect if not an open defiance of the prohibitions of the Constitution, intended for the protection of the people against such unauthorized action." Weeks v. United States, 232 U.S. 383, 394 (1914).

8277 U.S. 438 (1928). 
for the fruits of the illegality. He thought it better for some criminals to escape than for the government to "play an ignoble part."10 Justice Brandeis also spoke in moralistic terms of the need to "preserve the judicial process from contamination," but he added the pragmatic argument that illegally obtained evidence should be excluded to maintain respect for law and to promote confidence in the administration of justice. "If the Government becomes a law-breaker," he declared, in a much quoted passage, "it breeds contempt for law; . . . it invites anarchy." 11 More recently, the Supreme Court has declared that "[c]ourts which sit under our Constitution cannot and will not be made party to lawless invasions of the constitutional rights of citizens by permitting unhindered governmental use of the fruits of such invasions." 12 In other words, the government ought not be permitted to profit from its own wrong.

Although the normative justification that the Supreme Court has referred to as the "imperative of judicial integrity" 13 continues to appear in the rhetoric of Supreme Court decisions, it is doubtful that this argument decides cases. Despite bold pronouncements about not being a "party to lawless invasions," federal courts have not yet been forbidden from entering a valid judgment of conviction against a defendant who was brought before the court by illegal means such as kidnapping, arrest without probable cause, or arrest upon a warrant that was illegal or insufficient. ${ }^{14}$ Moreover, it is difficult to accept the proposition that the exclusion of improperly obtained evidence is necessary for "judicial integrity" when no such rule is observed in other common law jurisdictions such as England and Canada, ${ }^{15}$ whose courts are otherwise regarded as models of judicial decorum and fairness.

When the Supreme Court has had to make decisions on the scope of the exclusionary rule, its opinion has usually stressed and its reason-

$10 \mathrm{Id}$. at 470 .

11 Id. at 484-5. Professor Francis A. Allen gave modern voice to this argument by suggesting that "perhaps it may be urged that any process of law which sanctions the imposition of penalties upon an individual through the utilization of the fruits of official lawlessness tends to the destruction, not only of the rights of privacy, but of the whole system of restraints on the exercise of the public force which would seem to be inherent in the concept of civil liberty." Allen, The Wolf Case: Search and Seizure, Federalism, and the Civil Liberties, 45 ILL. L. REv. 1, 20 (1950).

12 Terry v. Ohio, 392 U.S. 1, 13 (1968).

13 Elkins v. United States, 364 U.S. 206, 222 (1960).

14 Ker v. Illinois, 119 U.S. 436 (1886); Frisbie v. Collins, 342 U.S. 519 (1952); Stallings v. Splain, 253 U.S. 339, 343 (1920); Albrecht v. United States, 273 U.S. 1, 8 (1927).

15 See generally Martin, The Exclusionary Rule under Foreign Law-Canada, $52 \mathrm{~J}$. Crum. L.C. \& P.S. 271 (1961); Williams, The Exclusionary Rule Under Foreign LawEngland, 52 J. CRIM. L.C. \& P.S. 272 (1961). 
ing seems to have been dictated by the factual considerations of deterrence rather than the normative arguments of judicial integrity. Thus, in Elkins $v$. United States, ${ }^{16}$ where the Court decided that evidence obtained in an illegal search by state officers must be excluded in a federal criminal trial, the Court gave this explanation of the exclusionary rule: "Its purpose is to deter-to compel respect for the constitutional guaranty in the only effectively available way-by removing the incentive to disregard it."17 The discursive prevailing opinion in Mapp v. Ohio ${ }^{18}$ quoted the Elkins statement and otherwise characterized the exclusionary rule as a "deterrent safeguard," but the decision does not clearly identify the primary basis for the rule because Justice Black's reliance on a self-incrimination theory split the majority on this question. ${ }^{19}$ These doubts were resolved in Linkletter $v$. Walker, ${ }^{20}$ where the Court decided that Mapp should not be given retrospective effect. Explaining that "the purpose [of the Mapp decision] was to deter the lawless action of the police," the Court reasoned that this purpose "will not at this late date be served by the wholesale release of the guilty victims."21

Deterrence was also the crucial factor in the Court's decisions on whether the new rules on interrogation warnings and lineup formalities should have retrospective application. ${ }^{22}$ Thus, in its most recent retroactivity decision, the Court held that the new requirements were binding only on lineups that occurred after the Wade decision. ${ }^{23}$ By fixing the effective date in terms of the police conduct rather than in terms of the time at which the trial court took its action in the matter, the Court has impliedly rejected the theory of "judicial integrity" and identified the exclusionary rule's primary purpose as that of con-

16364 U.S. at 222.

17 Id. at 217.

18367 U.S. at $648,656,676$ (1961).

19 Allen, supra note 3 , at 25 . A federal circuit court of appeals recently applied the Mapp precedent and rejected the judicial integrity rationale in a case in which Phillipine officers had obtained evidence by means that violated Phillipine law and that would have violated fourth amendment rights if obtained by United States officers. Relying on the fact that United States officers were not involved, the court upheld denial of the motion to suppress by a federal district court. Stonehill v. United States, 405 F.2d 738 (9th Cir. 1968), cert. denied, 395 U.S. 960 (1969).

20381 U.S. 618 (1965). See Comment, Standing to Object to an Unreasonable Search and Seizure, 34 U. CHI. L. REv. 342, 352 (1967), which discusses the various bases for the exclusionary rule and concludes that Linkletter "accepted a general deterrence rationale ...."

21381 U.S. at 637.

22 Johnson v. New Jersey, 384 U.S. 719 (1966); Stovall v. Denno, 388 U.S. 293 (1967).

The underlying decisions, Miranda and Wade, are cited in note 1 supra.

23 Stovall v. Denno, 388 U.S. 293 (1967). 
trolling police behavior. ${ }^{24}$ Finally, in an opinion concerning the retroactivity of its decision applying the self-incrimination privilege to the states, the Supreme Court stated that deterrence was the "single and distinct" purpose of the exclusionary rule. ${ }^{25}$

From the foregoing discussion it is apparent that the principal current argument for the exclusionary rule is a factual one: exclusion of evidence obtained by illegal means will deter law enforcement officials from the illegal behavior. ${ }^{26}$ "It is a logical enough theory, impregnable

24 Two authorities have urged that the renewed emphasis this gives to the factor of police reliance means that the retroactivity of all the Court's prospective rulings in the criminal procedure area will now be measured from the date of the police conduct. Schaefer, The Fourteenth Amendment and Sanctity of the Person, 64 Nw. U.L. REv. 1, 17 (1969); Kitch, The Supreme Court's Code of Criminal Procedure: 1968-1969 Edition, 1969 Sup. CT. REv. 155, 184.

The rationale for the exclusionary rule is less clear in Fahy v. Connecticut, 375 U.S. 85 (1963), where the Court held that a state could treat the admission of illegally obtained evidence as harmless error where there was no reasonable possibility that it had contributed to the defendant's conviction. This result is at odds with the logical requirements of either the "judicial integrity" or "deterrence" justifications for the rule. It is perhaps best understood as indicative of judicial ambivalence about the exclusionary rule itself. For similar opinions invoking the harmless error rule and exhibiting similar uncertainty about the rationale of the exclusionary rule in this context, see People v. Parkham, 60 Cal. 2d 378, 384 P.2d 1001, 33 Cal. Rptr. 497 (1963) (Traynor, J.); cases cited in Annot., 30 A.L.R.3d 128 (1968).

25 Tehan v. United States ex rel. Shott, 382 U.S. 406, 413 (1966). See also Kaufman v. United States, 394 U.S. 217 (1969). "[T]he raison d'etre of the exclusionary rule is the deterrence of lawless law enforcement. . . Traynor, Mapp v. Ohio at Large in the Fifty States, 1962 Duke L.J. 319, 334.

In times past the exclusionary rule has been described as giving a defendant a personal right not to be convicted by means of illegally obtained evidence. Wolf v. Colorado, 338 U.S. 25, 47-48 (1949) (Rutledge, J., dissenting); Boyd v. United States, 116 U.S. 616, 633 (1886); Allen, supra note 3, at 35. It has also been said to be based on a "personal incrimination theory" whereby it was a violation of the ffth amendment to convict a person on the basis of evidence seized in violation of the fourth amendment. Comment, supra note 20, at 347-50. And the rule has been explained in terms of requiring exclusion of the evidence as a kind of compensatory adjustment for the illegal invasion of the defendant's rights. Comment, Judicial Control of Illegal Search and Seizure, 58 YALE L.J. 144, 153-4 (1948). All of these alternative explanations have now been discredited. Kaufman v. United States, 394 U.S. 217, 229 (1969) (exclusionary rule "deemed necessary to protect the rights of all citizens, not merely the citizen on trial"); Hill, The Bill of Rights and the Supervisory Power, 69 Colvm. L. REv. 181, 183 n.14 (1969); Comment, supra note 20, at 352-3. Judge Friendly has stated that the defendant is allowed to exclude evidence "not primarily to vindicate his right of privacy, since the benefit received is wholly disproportionate to the wrong suffered," but to promote the security of citizens generally. Friendly, The Bill of Rights as a Code of Criminal Procedure, 53 CALIF. L. REv. 929, 951 (1965). Justice Traynor has declared that "the objective of the exclusionary rule is certainly not to compensate the defendant for the past wrong done to him ...." Traynor, supra, at 335.

26 "[T] he ultimate test of the exclusionary rules is whether they deter police officials from engaging in the objectionable practices." Allen, Due Process and State Criminal Procedures: Another Look, 48 Nw. U.L. REv. 1, 34 (1953). 
in the library."27 But a factually based rule that is probably the most important constitutional device for supervising criminal proceedings in state courts ${ }^{28}$ should have a more secure foundation than a theory that has never been tested. Yet today, more than fifty years after the exclusionary rule was adopted for the fedexal courts and almost a decade after it was imposed upon the state courts, there is still no convincing evidence to verify the factual premise of deterrence upon which the rule is based or to determine the limits of its effectiveness. ${ }^{29}$ Eminent judges, respected for their devotion to civil liberties, have voiced disapproval of the rule. ${ }^{30}$ Recent events in the United States Supreme Court suggest the possibility of modification. Plainly, it is time that the factual premises of the exclusionary rule were subjected to scrutiny.

\section{Evaluations of the Deterrent Effect of the EXClusionary Rule and OTHER ALternatives}

In adopting the exclusionary rule for federal courts the Weeks Court indulged two assumptions: (1) that exclusion of evidence would discourage illegal behavior, and (2) that there was no feasible alternative for controlling such behavior. ${ }^{31}$ Subsequent Supreme Court opinions have vacillated between conceding ignorance of these essential facts and simply asserting them. None has tendered anything remotely approaching evidence.

27 Waite, Evidence-Police Regulation by Rules of Evidence, 42 Mrch. L. REv. 679, 685 (1944).

28 Writing a year after the case was decided, a Pennsylvania prosecutor stated that Mapp v. Ohio "is the most significant event in criminal law since the adoption of the fourteenth amendment." Specter, Mapp v. Ohio: Pandora's Problems for the Prosecutor, 111 U. PA. L. REV. 4 (1962).

29 LaFave \& Remington, Controlling the Police: The Judge's Role in Making and Reviewing Law Enforcement Decisions, 63 Mrar. L. REv. 987, 1003 (1965); Allen, supra note 3 , at $32-40$.

30 Friendly, supra note 25, at 951-4; Schaefer, supra note 24, at 14. Recent academic criticism is sparse but growing. N. Morris \& G. HAwKIns, The Honest Politician's Guide To Crime Control 101 (1969); F. Inbau, J. Thomipson \& C. Sowle, Cases and Commients on Criminal Justice: Criminal law Administration 1-84 (3d ed. 1968); Burns, Mapp v. Ohio: An All-American Mistake, 19 DE PaUL L. REv. 80 (1969); Waite, supra note 27. The Inbau, Thompson \& Sowle book was a particularly valuable source in the preparation of this paper.

31 "If letters and private documents can thus be seized and held and used in evidence against a citizen accused of an offense, the protection of the Fourth Amendment declaring his right to be secure against such searches and seizures is of no value, and, so far as those thus placed are concerned, might as well be stricken from the Constitution." Weeks v. United States, 232 U.S. 383, 393 (1914). 


\section{A. Alternatives to the Exclusionary Rule}

This section will briefly review various methods that have been suggested for controlling illegal behavior by law enforcement personnel. Although an inquiry into the effectiveness of each method is beyond the scope of this article, it is important to have some general impressions on the question. The inappropriateness of an important federal constitutional right to freedom from unreasonable search and seizure without a clearly available federal remedy was surely a persuasive factor in the Supreme Court's eventual decision to impose the exclusionary rule..$^{32} \mathrm{It}$ is at least equally important today that there be an effective mechanism for redress of grievances against the police. ${ }^{33}$

Thus far, no method of enforcing constitutional guarantees and controls over illegal searches and seizures has demonstrated its effectiveness in practice. ${ }^{34}$ Although the law enforcement conduct involved in an improper search and seizure often constitutes a crime, the criminal law is not an effective instrument of control. ${ }^{35}$ Perhaps this is because in most cases involving police officers prosecutors will not prosecute and juries will not convict. An improper search and seizure is likewise a common law tort, but tort liability enforced by the aggrieved plaintiff is not thought to be an effective control because juries will be unwilling to find significant damages against police officers, especially in favor of a plaintiff who was an accused or convicted criminal. ${ }^{36}$ In addition, a judgment may not be collectible from the officer because of his inability to pay or from the employing government unit because of sovereign immunity or other legal barrier. ${ }^{37}$

32 Allen, supra note 3, at 2-20.

33 Report of the National Advisory Commission on Civil Disorders 162-3 (1968).

34 See generally W. Lafave, ARrest: The Decision to Take a Suspect Into Custody $411-27$ (1965); The President's CoMimission on LAW ENForcement and AdMinistration of Justice, TASK Force Report: The POLICE 193-207 (1967) [hereinafter cited as TASK Force REPORT: ThE PolicE]; authorities cited in Kamisar, Wolf \& Lustig, Ten Years Later: Illegal State Evidence in State and Federal Courts, 43 MrNN. L. Rev. 1083, 1150 n.238 (1959).

35 Edwards, Criminal Liability for Unreasonable Searches and Seizures, 41 VA. L. REv. 621 (1955).

36 Foote, Tort Remedies for Police Violations of Individual Rights, 39 MINN. L. REv. 493 (1955). See generally Symposium on Police Tort Liability, 16 Clev.-MAR. L. REv. 397-454 (1967).

37 Several authorities have proposed legislation to impose liability on political subdivisions whose officers committed an offense. 3 K.C. Davis, Administrative Law Treatise $\S \S 25.17,26.03$ (1958); Mathes \& Jones, Toward a "Scope of Official Duty" Immunity for Police Officers in Damage Actions, 53 GEo. L.J. 889 (1965); Barrett, Exclusion of Evidence Obtained by Illegal Searches-A Comment on People v. Cahan, 43 Calif. L. REV. 565, 579 (1955). A few states provide indemnity for officers held liable for damages for injuries inflicted while they are engaged in the performance of their duties. ILL. REv. StAT. ch. 24, §§ 1-4-5 \& 1-4-6 (1969). Thus far there is no showing that either 
The federal statutory cause of action under the Civil Rights Act, section 1983, is another possibility that has not been demonstrated to be an effective deterrent of illegal behavior. ${ }^{38}$ Jury reluctance and the insufficient measure of damages are probably the outstanding diffculties. There are some omens of change in these areas, ${ }^{39}$ but an effective tort remedy is still unrealized.

All law enforcement agencies have some internal administrative review and discipline for officers who violate laws or department regulations, but interested outsiders generally distrust the objectivity of such procedures. Internal review is not looked upon as an effective mechanism for insuring adherence to the constitutional and statutory rights of those suspected of crime. An outside review body with disciplinary powers, such as a civilian review board or an ombudsman, seems to be a better prospect in theory. Unfortunately, there is virtually no United States experience with an ombudsman in this role, and the civilian review boards that have operated in the past few years have been recommending bodies, with little or no power of decision and enforcement. ${ }^{40}$ Consequently, there is insufficient experience to determine whether either of these alternatives could effectively control police behavior. Another recent suggestion would have courts enforce individual rights by citing offending law enforcement officers for contempt of court, ${ }^{41}$ but thus far there has been virtually no experience with this remedy.

\section{B. The Deterrent Effect of the Exclusionary Rule}

In Irvine v. California, ${ }^{42}$ Justice Jackson achieved a degree of candor still unequalled by declaring:

What actual experience teaches we really do not know. Our cases evidence the fact that the federal rule of exclusion and our reversal of conviction for its violation are not sanctions which put an end to illegal search and seizure by federal officers. . . . There is no reliable evidence known to us that inhabitants of those states which exclude the evidence suffer

enlarged liability or indemnity has realized the expectation that government agencies exposed to this prospect of liability would take steps to minimize their risk by effectively reducing police misbehavior.

38 The leading case in search and seizure is Monroe v. Pape, 365 U.S. 167 (1961).

39 See text accompanying note 148 infra.

40 Task Force Report: The Police at 200-4.

41 Comment, Federal Injunctive Relief From Illegal Search, 1967 WAsH. U.L.Q. 104; Comment, The Federal Injunction as a Remedy for Unconstitutional Police Conduct, 78 YALE L.J. 143 (1968); Comment, Use of § 1983 to Remedy Unconstitutional Police Conduct: Guarding the Guards, 5 HARv. Crv. RIGHTs-Crv. LIB. L. REv. 104 (1970).

42347 U.S. 128, 135-7 (1954). 
less from lawless searches and seizures than those of states that admit it.

Similarly, in Elkins $v$. United States, ${ }^{43}$ Justice Stewart conceded that "[e]mpirical statistics are not available" to show that the exclusionary rule reduces the incidence of lawless searches and seizures. Justice Clark's opinion in Mapp $v$. Ohio ${ }^{44}$ asserts that the exclusionary rule deters police from violating constitutional guarantees by removing the incentive to disregard them, and that the alternative remedies have been "worthless and futile." But the opinion offers no evidence to substantiate either assertion. In fact, Mapp reversed the Wolf case and imposed the exclusionary rule on more than a score of states even though the question was not raised in the briefs and was only touched on tangentially in the oral argument. ${ }^{45}$

At the time of the Mapp decision, the sum total of published empirical evidence on the deterrent effect of the exclusionary rule consisted of eleven responses to Justice Murphy's inquiries about the extent of police training in areas with and without the exclusionary rule, a student comment suggesting that the rule did not deter unlawful methods in the enforcement of gambling laws in Chicago in 1950, and some commentary aimed at refuting the contention that the exclusionary rule had crippled law enforcement in areas where it had been adopted. All of this evidence is discussed in the next section. ${ }^{46}$

Once the Supreme Court invoked its authority to make the exclusionary rule a matter of constitutional imperative, it took little time for the Court's familiarity with the rule to become certainty as to its deterrent effect. In Linkletter $v$. Walker, ${ }^{47}$ Justice Clark's opinion referred to the exclusionary rule as "the only effective deterrent against lawless police action." Chief Justice Warren repeated that extravagant praise in Terry $v$. Ohio, ${ }^{48}$ and even suggested that the heroic proportions of the rule rose out of something more than assertion:

[I]ts major thrust is a deterrent one [citing Linkletter $v$. Walker], and experience has taught that it is the only effective deterrent to police misconduct in the criminal context. . . .49

43364 U.S. 206, 218 (1960).

44367 U.S. $643,652,656$ (1961).

$45 \mathrm{Id}$. at 676.

40 See text accompanying notes 65,72 \& 79 infra.

47381 U.S. 618,636 (1965).

48392 U.S. 1 (1968).

19 Id. at 12 (emphasis added). 
Justice Roger Traynor was equally enthusiastic in People v. Cahan, ${ }^{50}$ which adopted the exclusionary rule for California. His influential opinion asserts that adoption of the exclùsionary rule "will discourage" illegal searches and seizures, and that it "will also arouse public opinion as a deterrent to . . . law enforcement officers who allow criminals to escape by pursuing them in lawless ways." 51

Informed observers other than the United States Supreme Court have uniformly agreed that presently available alternatives for deterring police misconduct are ineffective. ${ }^{52}$ But these authorities have generally been more guarded than the Supreme Court in their characterization of the exclusionary rule's potential for deterrence. In a 1950 article Francis A. Allen wrote:

One seeking to discover the actual consequences of the exclusionary rule in protecting individual rights of privacy and its effects upon the process of law enforcement cannot fail to be impressed by the paucity of empirical evidence upon which anything more than highly tentative conclusions may be based. Data to supply adequate answers to even elementary questions is largely non-existent. ${ }^{53}$

Despite the lack of data, Professor Allen offered the opinion that the rule had "substantial regulative effect," because it subjected the individual officer "to the pressure of those charged with making an efficient record of criminal convictions to avoid conduct which imperils successful prosecution." $\mathrm{He}$ also urged that the "regulative effect of public opinion . . . is more likely to become a reality where the consequence of an official invasion of privacy may be to deprive the state of power to secure the conviction of a serious offender." Edward L. Barrett, Jr. was cautious in his declaration that " $[t]$ he factual question regarding the effectiveness of the rule cannot be answered in any satisfactory fashion without detailed field studies of the actual operations of law enforcement officials and the effect upon them of the exclusionary rule."55

Writing while a judge of the court of appeals, Chief Justice Warren E. Burger took a negative view of the deterrent capacity of the exclusionary rule, though he was equally obscure about the factual basis for his conclusion:

5044 Cal. 2d 434, 282 P.2d 905 (1955).

51 Id. at $448-9,282$ P.2d at 913-4.

52 See authorities cited notes 34-41 supra.

53 Allen, supra note 11 , at 16-17.

54 Id. at 20.

55 Barrett, supra note 37, at 584 . 
Some of the most recent cases in the Supreme Court reveal, almost plaintively, an unspoken hope that if judges say often and firmly that deterrence is the purpose, police will finally take notice and be deterred. As I see it, a fair conclusion is that the record does not support a claim that police conduct has been substantially affected by the suppression of the prosecution's evidence .... .

I suggest that the notion that suppression of evidence in a given case effectively deters the future action of the particular policeman or of policemen generally was never more than wishful thinking on the part of the courts. ${ }^{56}$

Monrad Paulsen tenders the cautious appraisal that the exclusionary rule "is the best we have," 57 and that it is "the most effective remedy we possess to deter police lawlessness." 58 Nevertheless, he asserts that "there are reasons to believe that the exclusionary rule has an important practical influence," 59 and that the rule "creates a genuine incentive for police departments to educate their members in the constitutional rights of suspected persons." 60

Yale Kamisar, another enthusiast for the exclusionary rule, treats the question of the factual basis for the rule in this manner:

The fact that there is little agreement and little evidence that the exclusionary rule does deter police lawlessness is much less significant, I think, than the fact that there is much agreement and much evidence that all other existing alternatives do not. ${ }^{.1}$

Professor Kamisar is obviously too careful a thinker to be suggesting that the absence of deterrent effect by any of the existing alternatives establishes the deterrent value of the exclusionary rule. That there is no alternative cure for cancer does not prove the effectiveness of treatment by the "expressed juice of the woolly-headed thistle." 62

58 Burger, Who Will Watch The Watchman?, 14 AM. U.L. REv. 1, 11-12 (1964).

67 Paulsen, Safeguards in the Law of Search and Seizure, 52 Nw. U.L. REv. 65, 74 (1957).

58 Paulsen, The Exclusionary Rule and Misconduct by the Police, 52 J. CRm. L.C. \& P.S. 255, 257 (1961).

58 Id. at 260.

60 Paulsen, supra note 57 , at 74 .

61 Kamisar, supra note 34 , at 1150 .

62 Recommended in Prudence Smith's Modern American Cookery of 1831 according to J. Furnas, The Americans 338 (1969).

If the exclusionary rule does have a measurable deterrent effect, then the lack of feasible alternatives helps to justify the use of the rule even though it has undesirable side effects. But if no positive case can be made for the deterrent effect of the rule, then the lack of feasible alternatives adds nothing to the case. "[I]n the final analysis, the justification for the imposition of the rule on the reluctant states must rest on the 
Kamisar is merely saying what the Supreme Court and a considerable number of scholars have said over and over again, ${ }^{63}$ that in the absence of any better alternative, we are willing to take the deterrent effect of the exclusionary rule solely on the basis of assumption.

In sum, the rhetoric concerning the factual basis for the exclusionary rule amounts to no more than "fig-leaf phrases used to cover naked ignorance." 64

\section{Attempts to Measure the Effect of the Exclusionary RULE}

This section examines both previously published and newly compiled evidence on the effect of the exclusionary rule pertaining to search and seizure on the criminal justice system, particularly on law enforcement personnel. Three research methods are represented in this data. The before-after method compares the conduct of law enforcement officers or the operation of the criminal justice system before and after adoption of the exclusionary rule. The multiple-area method compares the conduct of law enforcement officers or the operation of the criminal justice system in a jurisdiction that has the exclusionary rule with a jurisdiction that does not. These first two methods compare the effect of the rule at different times or in different jurisdictions. The third method, field observation, tries to determine the effect of the rule in a single area during a single period of time, such as by drawing inferences from the proportion of motions to suppress that are granted in a particular crime. The information has been obtained from a variety of sources including questionnaires, criminal justice system statistics and observation. The data is grouped according to those sources.

\section{A. Questionnaire Results}

The first recorded attempt to test empirically the factual assumptions underlying the exclusionary rule was Justice Murphy's question-

affirmative case that can be made for the rule, not on the inefficacy of the tort suit, police discipline, or whatever else may be suggested as a substitute." Allen, supra note 3 , at 33 n.172.

63 Justice Traynor is a notable example: "We have been compelled to reach that conclusion [adopting the exclusionary rule] because other remedies have completely failed to secure compliance with the constitutional provisions on the part of police officers ...." People v. Cahan, 44 Cal. 2d 434, 445, 282 P.2d 905, 911 (1955); "police methods of obtaining evidence were not being deterred in any other way. ... [T] here was no recourse but to the exclusionary rule." Traynor, supra note 25 , at $322,324$.

64 To borrow a phrase Will Durant applied to the incautious verbiage of philosophy. W. Durant, The Story of Philosophy 101 (1926). 
naire, described in his dissent in Wolf $v$. Colorado. ${ }^{65}$ Randomly selecting 38 large cities, he sent written inquiries about the extent of police training in the rules of search and seizure. He received 26 replies, but his opinion characterized only 11 of these. Table 1 summarizes the results.

TABLE 1

Police Training in SEARCh aNd SEIzURE

RuLES IN 11 CITIES IN 1949

\begin{tabular}{llcc}
\hline $\begin{array}{l}\text { Extent of } \\
\text { Police Training }\end{array}$ & $\begin{array}{c}\text { In Cities in States } \\
\text { with } \\
\text { the Exclusionary Rule }\end{array}$ \\
\hline Negligible & 1 & 4 \\
Extensive & 5 & 1 \\
Total & $\overline{6}$ & $\overline{5}$ \\
\hline
\end{tabular}

Justice Murphy concluded: "The contrast between states with the federal rule and those without it is thus a positive demonstration of its efficacy." While Justice Murphy is to be praised for attempting to investigate what his fellow judges have generally been willing to take on assumption, it is regrettable that he failed to disclose the nature of all the replies, and that he so obviously overstated the conclusion to be drawn from his data. Even if one ignored the smallness of the sample and conceded that this survey showed more police training in jurisdictions with the exclusionary rule, police training is only the first step. The ultimate inquiry is whether the training affects police behavior.

A wider range of opinion about police training and other effects of the exclusionary rule was elicited by Stuart S. Nagel's 1963 questionnaire concerning the Mapp decision. These inquiries were mailed to 250 persons, five in each state. The recipients, randomly chosen in their individual categories, consisted of a police chief, a prosecuting attorney, a judge, a defense attorney and an American Civil Liberties Union official. Questionnaires were returned by 113 recipients (45\%), representing 47 states and consisting of roughly equal proportions of the five categories. Nagel's hypothesis was that between 1960 and 1963 the 24 states that had been forced to adopt the exclusionary rule (by the 1961 Mapp decision) would have undergone more changes of various kinds relevant to the rule than the 23 states that had been applying an exclusionary rule before Mapp. The Table 2 summary of the questionnaire returns, which of course merely represents an

65338 U.S. $25,44-46$ (1949).

66 Id. at 46. 
accumulation of the opinions of the persons questioned, supports Nagel's hypothesis. ${ }^{67}$

TABLE 2

OpINIONS ON EFFECT OF EXCLUSIONARY RULE ON

PoLICE BeHAVIOR, 1960 TO 1963

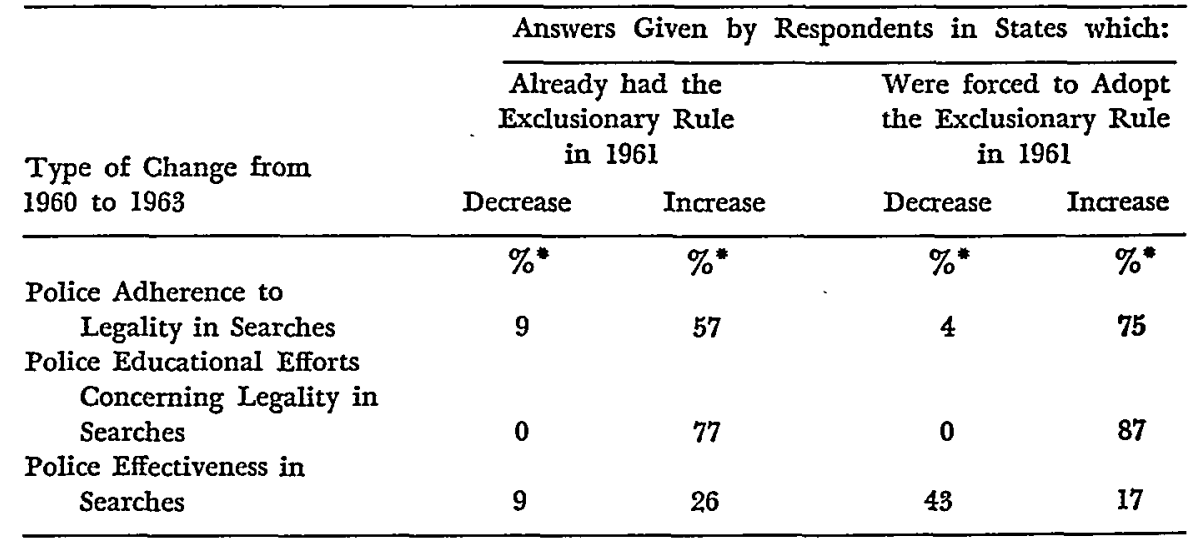

* $100 \%=$ Per cent of decrease plus per cent of increase plus per cent of those states which reported "no change." E.g., the changes in police adherence to legality in searches in states that already had the exclusionary rule were $9 \%$ decrease, $57 \%$ increase and $34 \%$ no change.

This data shows a comparatively larger increase in adherence to legal standards and in educational efforts in those states that had just been compelled to adopt the exclusionary rule. But it also shows a comparatively larger decrease in the effectiveness of the police in these states.

In other opinion evidence, individual law enforcement personnel

67 Nagel, Testing the Effects of Excluding Illegally Seized Evidence, 1965 WIs. L. REv. 283, 283-6. Other subjects covered in the questionnaire or treated in the article, such as the frequency of raising search and seizure subjects (as measured by the number of headnotes in the West Digest), possible effects as measured by state crime statistics, and questions about the declarant's attitude toward the exclusionary rule, are omitted here because the data they yield are not considered significant.

A somewhat similar questionnaire returned by 90 police chiefs, sheriffs, trial judges, prosecutors and defense counsel in North Carolina showed that about three-quarters felt that the exclusion of evidence was an effective way to reduce the number of illegal searches. Katz, Supreme Court and the State: An Inquiry into Mapp v. Ohio in North Carolina, 45 N.C.L. REv. 119 (1966).

A questionnaire answered by 30 police chiefs and sheriffs in Colorado shows that only $20 \%$ of them felt that the decision making illegally obtained evidence inadmissible would "substantially" affect their departments' search and seizure practice. The other returns stated that it would affect their practices only "slightly" (47\%) or "not at all" (33\%). Weinstein, Local Responsibility for Improvement of Search and Seizure Practices, 34 Rocky Mr. L. REv. 150, 176 (1962). It was unclear whether the latter answers reflected a high degree of legality preceding Mapp or a low degree of conformity after. 
and outside observers have expressed the view that imposition of the exclusionary rule has resulted in increased police awareness and observance of search and seizure rules. ${ }^{68}$

\section{B. Motions to Suppress}

Court statistics show the astonishing extent to which the exclusion of evidence-as measured by the incidence of motions to suppress-is concentrated in a few crimes. Table 3 includes all motions to suppress, not just those involving searches and seizures, but knowledgeable observers in Chicago and the District of Columbia confirm that search and seizure issues account for an overwhelming proportion of these motions.

Table 3 shows that over 50 per cent of the motions to suppress in Chicago and the District were filed in cases involving narcotics and weapons, even though these crimes accounted for a comparatively small proportion of the total number of persons held for prosecution. ${ }^{69}$ (The nationwide figures show that only 2 per cent of the total number of persons held for prosecution were charged with weapons or narcotics offenses.) In Chicago an additional 26 per cent of the motions to suppress were filed in gambling cases, which account for only 1 per cent of the national total of persons held for prosecution. It may be argued that the low incidence of motions to suppress in some crime categories signifies that the exclusionary rule is extraordinarily effective in those categories. A more likely explanation is that the

68 Kamisar, supra note 34, at 1145-58; Paulsen, supra note 58, at 263. Though it has been said that such individual observations "fulfill the fondest hopes and expectations of proponents of the exclusionary rule," Kamisar, supra note 34, at 1158, they are insufficient to constitute persuasive empirical evidence of the deterrent capacity of the rule.

00 For a discussion of important differences in the time and manner in which motions to suppress are litigated in Chicago and the District, see text following note 76 infra.

The District's felony motions to suppress are also concentrated, though the mixture of offenses is different. The 142 motions to suppress disposed of in felony cases in 1965 were grouped as follows:

$\begin{array}{lr}\text { Distribution of Motions to } & \\ \text { Suppress in Felony Cases } & \% \\ \text { Robbery, burglary and other } & \\ \text { property offenses } & 42 \\ \text { Narcotics } & 18 \\ \text { Violence against person } & 15 \\ \text { Gambling } & 10 \\ \text { Weapons } & 6 \\ \text { White-collar crimes } & 4 \\ \text { All other } & 5 \\ \text { TOTAL } & 100 \\ & (142)\end{array}$

Computed from data in Table 7 infra. 
TABLE 3

Distribution of Motions to SUPPREsS among VARIOUS

Crimes in Chicago and District of Columbia, 1969-70

\begin{tabular}{|c|c|c|c|}
\hline \multirow[b]{2}{*}{ Offense } & \multicolumn{2}{|c|}{$\begin{array}{c}\text { Proportion of Total Motions } \\
\text { to Suppress }\end{array}$} & \multirow{2}{*}{$\begin{array}{l}\text { Proportion of } \\
\text { Total Persons } \\
\text { Held for } \\
\text { Prosecution } \\
\text { (United States) }\end{array}$} \\
\hline & Chicago & $\begin{array}{l}\text { District of } \\
\text { Columbia }\end{array}$ & \\
\hline Narcotics & $\begin{array}{l}\% \\
24\end{array}$ & $\begin{array}{l}\% \\
35\end{array}$ & $\begin{array}{r}\% \\
1\end{array}$ \\
\hline Weapons & 28 & 26 & 1 \\
\hline Gambling & 26 & 4 & I \\
\hline Disorderly Conduct & 11 & $\bullet$ & 10 \\
\hline $\begin{array}{l}\text { Theft, Burglary, } \\
\text { Receiving and oth }\end{array}$ & & & \\
\hline Property Offenses & 4 & 19 & 15 \\
\hline Assault & $*$ & 1 & 6 \\
\hline $\begin{array}{c}\text { Two or More of } \\
\text { Above Crimes }\end{array}$ & * & $15 \mathrm{~b}$ & 一 \\
\hline All Other Crimes & $7 \mathfrak{a}$ & $*$ & 66 \\
\hline Total & $\begin{array}{c}\frac{100}{(649 \text { motions }} \\
\text { in } 12 \text { court days) }\end{array}$ & $\begin{array}{l}\frac{100}{(69 \text { motions }} \\
\text { in } 2 \text { months) }\end{array}$ & $\begin{array}{c}100 \\
(2.3 \text { million } \\
\text { persons) }\end{array}$ \\
\hline
\end{tabular}

- Signifies less than $.5 \%$.

a No other category exceeded $2 \%$.

b Consists of motions in cases involving two or more types of charges: property and narcotics, $4 \%$; property and weapons, $3 \%$; property and assault, $3 \%$; other combinations, $5 \%$.

Source: Chicago data for misdemeanors and preliminary hearings in felonies, compiled from examination of court records in all 14 branches of the First District of the Municipal Department of the Circuit Court of Cook County hearing criminal cases for 12 sample days in 1969: Jan. 15, Feb. 14, March 13, Apr. 15, May 15, June 16, July 15, Aug. 15, Sept. 15, Oct. 15, Nov. 13, and Dec. 15. District of Columbia data for misdemeanors only, compiled from examination of court records in motions court of Court of General Sessions for every motion day in March and April, 1970. Data in both areas include only those motions disposed of by grant or denial during the period. United States data computed from FEDERAL BuREAU OF INVESTIGATION, UNIFORM CRIME REPORTS 109 (1967).

frequency of motions to suppress is a function of the relative importance, in the prosecution of a particular type of crime, of evidence that is obtained by means that can reasonably be challenged as improper..$^{70}$

70 Narcotics, weapons, and gambling are all crimes where one piece of physical evidence -generally obtained from the person or premises of the accused-is vital to the prosecution. This is not true of offenses such as auto theft or assault, which also rank high in the number of reported crimes but rarely involve a motion to suppress. The property offenses are mixed. Some, like receiving stolen property, possession of burglary tools and a theft charge based on possession, are likely to involve questions of the legality of search and seizure, whereas others are not. Of course a motion to suppress may also challenge an identification or the use of a statement taken from the accused, and in this manner motions to suppress may figure in criminal charges that seldom involve questions of search and seizure. 
If so, then the law enforcement conduct that is supposed to be deterred by the exclusionary rule will probably be concentrated in the enforcement of those few crimes where motions to suppress are most numerous. Whether or not one accepts that hypothesis, the unequal distribution of motions to suppress among various crime categories should at least make one wary of attempts to use overall crime statistics as an index of the effect of the exclusionary rule.

Within the various crimes where motions to suppress are concentrated, there are wide variations in the proportion of cases where there is a motion to suppress and in the proportion of motions granted. These variations are direct evidence of the effect of the exclusionary rule on the criminal justice system, and they may also provide indirect evidence on the extent of its deterrent effect on the police.

The most extensive empirical inquiry preceding the decision in Mapp v. Ohio was a student study ${ }^{71}$ of motions to suppress during 1950 in the branch of the Chicago Municipal Court that handled all gambling and narcotics violations and some weapons charges. Table 4 contains the data from this student study. Table 5 contains the equivalent data for 1969, when the same cases were divided between two branches of the Circuit Court. In each table the figures represent motions during preliminary hearings of felonies and trials of misdemeanors. These are not before-after comparisons, since Illinois adopted the exclusionary rule long before 1950, and it was in effect during the entire period covered by these tables.

Table 4 shows that 77 per cent of the defendants in gambling cases in 1950 moved to suppress, and that 99 per cent of these motions were granted. In no case was a conviction secured after the suppression of evidence. Consequently, the motion to suppress was the dispositive event for 76 per cent of the defendants charged with gambling offenses in Chicago in 1950. The student authors concluded that their study had shown that as to gambling cases:

[T] he rule has failed to deter any substantial number of illegal searches. ... These figures . . . may indicate that the exclusionary rule is most effective in discouraging illegal searches in cases involving serious offenses, where conviction is important. Conversely, where the police believe that a policy of harassment is an effective means of law enforcement, the exclusionary rule will not deter their use of unlawful methods. ${ }^{72}$

71 Comment, Search and Seizure in Illinois: Enforcement of the Constitutional Right of Privacy, 47 Nw. U.L. REv. 493, 498 (1952).

72 Id. at 497-8. This conclusion is reinforced by data from another jurisdiction, where 
TABLE 4

Motions to Suppress in Gambling, WeApons AND

NARCotics CASES IN BRANGH 27 OF THE

MUNicipal Court of Chicago, 1950

\begin{tabular}{|c|c|c|c|c|}
\hline Offense & $\begin{array}{c}\text { No. of } \\
\text { Defendants }\end{array}$ & $\begin{array}{l}\text { Defendants } \\
\text { with Motion } \\
\text { to Suppress } \\
\text { (a) }\end{array}$ & $\begin{array}{l}\text { Motions } \\
\text { Granted } \\
\text { (b) }\end{array}$ & $\begin{array}{l}\text { Defendants } \\
\text { with Motion } \\
\text { Granted } \\
\text { (a) } \times \text { (b) }\end{array}$ \\
\hline Gambling & (461) & $81^{\%}$ & $100^{\%}$ & $81^{\%}$ \\
\hline Policy (numbers) & $(2,133)$ & 73 & 98 & 71 \\
\hline $\begin{array}{l}\text { Keeper of } \\
\text { Gaming House } \\
\text { City Gambling }\end{array}$ & (791) & 88 & 99 & 87 \\
\hline Charges* & $(2,463)$ & 75 & 99 & 74 \\
\hline $\begin{array}{l}\text { All Gambling Offenses } \\
\text { Narcotics } \\
\text { Carrying Concealed }\end{array}$ & $\begin{array}{r}(5,848) \\
(288)\end{array}$ & $\begin{array}{l}77 \\
19\end{array}$ & $\begin{array}{r}99 \\
100\end{array}$ & $\begin{array}{l}76 \\
19\end{array}$ \\
\hline Weapons & $(513)$ & 28 & 91 & 25 \\
\hline All Offenses Above & $\overline{(6,649)}$ & $\overline{70}$ & $\overline{98}$ & $\overline{69}$ \\
\hline
\end{tabular}

* Covers such charges as inmate of a gambling house; violations always occurred in conjunction with other gambling offenses.

The 1969 figures for gambling offenses are lower than those for 1950 , but are still high by comparison with other crimes. There were motions to suppress in 52 per cent of the gambling cases and 86 per cent were granted. Since the charges were immediately dismissed in every case where a motion to suppress was granted, the motion to suppress was the dispositive event in 45 per cent of the gambling cases in Chicago in 1969. Although somewhat lower than in 1950, that total is still sufficiently high to cast serious doubt upon the effectiveness of the exclusionary rule to deter illegal searches and seizures in the enforcement of gambling laws in Chicago.

This does not prove that the exclusionary rule has no deterrent effect in gambling cases. The rule may have some effect in those cases where motions are denied, and it may also affect enforcement activities that do not result in prosecutions. But the figures at least show that the exclusionary rule has not been effective in persuading the Chicago

there were 80 raids on alleged gambling operations during a six-month period, resulting in 580 arrests, but not more than 25 of these persons were prosecuted. Goldstein, Police Discretion not to Invoke the Criminal Process: Low-Visibility Decisions in the Administration of Justice, 69 YALE L.J. 543, $584 \mathrm{n} .89$ (1960). During the same period, criminal prosecutions were initiated against only 75 of 3,000 women arrested for prostitution. For a discussion of why the exclusionary rule is unlikely to be a significant deterrent upon police conduct in gambling and prostitution, see W. LAFAVE, supra note 34, at chs. $22,24$. 
TABLE 5

Motions to SUPPRESS IN GAMBLING, WeAPONS AND

Narcotics Gases in Branches 27 and 57 of the Circuit Court in Chitcago for 12 SAmple Days in 1969

\begin{tabular}{|c|c|c|c|c|}
\hline Offense & $\begin{array}{c}\text { No. of } \\
\text { Defendants }\end{array}$ & $\begin{array}{c}\text { Defendants } \\
\text { with Motion } \\
\text { to Suppress } \\
\text { (a) }\end{array}$ & $\begin{array}{l}\text { Motions } \\
\text { Granted } \\
\text { (b) }\end{array}$ & $\begin{array}{l}\text { Defendants } \\
\text { with Motion } \\
\text { to Suppress } \\
\text { Granted } \\
\text { (a) } \times \text { (b) }\end{array}$ \\
\hline Gambling & (86) & $80^{\%}$ & $74^{\%}$ & $59^{\%}$ \\
\hline Keeper of Gaming House & (38) & 53 & 85 & 45 \\
\hline City Gambling Charges & (188) & 39 & 97 & 38 \\
\hline All Gambling Offenses & (312) & 52 & 86 & 45 \\
\hline Narcotics & $(457)$ & 34 & 97 & 33 \\
\hline Carrying Concealed Weapons & (188) & 36 & 68 & 24 \\
\hline All Offenses Above & $\overline{(957)}$ & $\overline{40}$ & $\overline{87}$ & $\overline{35}$ \\
\hline
\end{tabular}

Same source and sample days as listed in Table 3. The 649 total motions shown in Table 3 for the whole Circuit Court is composed of the 386 motions shown above (40\% of 957), 141 other motions to suppress in Branches 27 and 57 (including 65 in gun registration and city gun cases, 52 in disorderly conduct, 6 in assault and 4 in theft), and 122 motions in all other branches of the Circuit Court. The subject-matter breakdown appears in Table 3.

police to observe the search and seizure rules in anywhere near as high a proportion of cases as they are able. If the Chicago police were serious about observing the search and seizure law in gambling cases they should be able to observe the rules with enough consistency that no more than a small fraction of charges would be dismissed after the granting of a motion to suppress.

The same may be said of narcotics and weapons cases, though these figures are somewhat lower than those for gambling. In 1950 the number of narcotics defendants who were dismissed after a motion to suppress was a comparatively low 19 per cent. In 1969 there were about 50 times as many narcotics cases ( 457 for 12 sample days in 1969 compared with 288 for a whole year in 1950), and the number disposed of by motions to suppress had climbed to 33 per cent. ${ }^{73}$ The 1950 and 1969 figures for defendants charged with carrying a concealed weapon are practically identical, 25 and 24 per cent, respectively. The narcotics and weapons figures of 33 and 24 per cent of defendants being released because of illegally obtained evidence seem

73 Similarly, a 1964 sample of 70 Chicago narcotics cases showed motions to suppress in 29 cases, with 22 of these granted, for a total disposition by motion to suppress of 31 per cent. D. Oaks \& W. Lehiman, A Criminal Justice System and the Indigent: A Study OF Chicago and CoOK COUNTY 88-89 (1968). 
considerably higher than would be necessary if the Chicago police were really serious about observing the search and seizure rules.

Current data on all motions to suppress in the District of Columbia provides an illuminating contrast. Tables 6 and 7 show the figures for misdemeanors and felonies.

TABLE 6

MOTIONS to SUPPRESS IN MisDEMEANOR GASES, District of Columbia Court of General Sessions,

MARCH \& APRIL, 1970

\begin{tabular}{lcc}
\hline Offense & No. of Motions & No. Granted \\
\hline Gambling & 3 & 0 \\
Narcotics & 24 & 6 \\
Weapons & 18 & 3 \\
Property Offenses & 13 & 1 \\
Assault & 1 & 0 \\
Combination of Above & 10 & 4 \\
Total & $\overline{69}$ & $\overline{14}$ \\
& & $(20 \%)$
\end{tabular}

Source: Same as Table 3. Includes all motions to suppress granted or denied during period, but excludes motions continued or withdrawn. No data available on the number of defendants charged with each crime or on the disposition of defendants for whom the motion was granted.

TABLE 7

Motions to Suppress in Ferony CAses,

District COURT FOR tHE District OF COLUMBIA, 1965

\begin{tabular}{|c|c|c|c|c|}
\hline Offense & $\begin{array}{c}\text { No. of } \\
\text { Charges }\end{array}$ & $\begin{array}{l}\text { Charges with } \\
\text { Motion to } \\
\text { Suppress } \\
\text { (a) }\end{array}$ & $\begin{array}{l}\text { Motions } \\
\text { Granted } \\
\text { (b) }\end{array}$ & $\begin{array}{l}\text { Charges with } \\
\text { Motion } \\
\text { Granted } \\
\text { (a) } \times \quad \text { (b) }\end{array}$ \\
\hline Gambling \& Lottery & (119) & $\begin{array}{l}\% \\
12\end{array}$ & $\begin{array}{l}\% \\
14\end{array}$ & $\begin{array}{r}\% \\
2\end{array}$ \\
\hline Narcotics & (109) & 23 & 16 & 4 \\
\hline Weapons & (141) & 6 & 2 & 1 \\
\hline Robbery, Burglary \& Theft & $(1,138)$ & 5 & 8 & $\bullet$ \\
\hline Homicide, Rape \& Assault & $(558)$ & 4 & 27 & 1 \\
\hline Fraud, Forgery, Counterfeiting & & & & \\
\hline \&. Embezzlement & (160) & 3 & 0 & - \\
\hline Other Crimes & (83) & 8 & $\mathbf{0}$ & $*$ \\
\hline All Offenses Above & $(2,308)$ & $\begin{array}{r}6 \\
(142)\end{array}$ & $\begin{array}{l}13 \\
(19)\end{array}$ & $\begin{array}{c}1 \\
(19)\end{array}$ \\
\hline
\end{tabular}

- Signifies less than $5 \%$.

Source: Number of charges from tables prepared by staff of the President's Commission on Crime in the District of Columbia, p. I; figures on motions to suppress from President's Commission on Crime in the District of Columbia, unpublished computer printouts, pp. 23-24. All data is in possession of Sylvia Bacon, Executive Assistant United States Attorney for the District of Columbia. 
The figures on motions to suppress in Chicago and the District of Columbia are in sharp contrast at every level. A few examples will suffice. The per cent of gambling cases in which there is a motion to suppress is 81 per cent for Chicago but 12 per cent for the comparable felony in the District. In the felony of carrying concealed weapons, there is a motion to suppress in 36 per cent of the cases in Chicago but 6 per cent in the District. The per cent of motions granted in narcotics offenses is 97 per cent in Chicago but 25 per cent for misdemeanors and 16 per cent for felonies in the District. The number of defendants who have a motion to suppress granted in weapons and narcotics cases is 24 and 33 per cent in Chicago but 1 and 4 per cent for felonies in the District. On this last example the contrast is even larger than the figures indicate, since all of the Chicago defendants were dismissed when their motion was granted, whereas only about half of the District felony cases were dismissed in this manner. ${ }^{74}$

An even more significant contrast between Chicago and the District of Columbia is in the number of motions to suppress. When the totals in Tables 5 through 7 are converted to monthly figures, Chicago has about 1,140 motions to suppress per month and the District has about 47 . When these figures are adjusted for differences in the number of reported arrests, Chicago has about two and one-half times more motions to suppress in felonies and misdemeanors than the District of Columbia. ${ }^{78}$

Such contrasts are clearly attributable to important differences in the criminal justice systems of the two cities. These include differences

74 The manner of disposition of the 19 felony cases in which a motion to suppress was granted (see Table 7) was as follows:

\begin{tabular}{lcccc} 
& $\begin{array}{c}\text { No. of } \\
\text { Motions }\end{array}$ & \multicolumn{3}{c}{ Disposition of Case } \\
\cline { 5 - 6 } Offense & Granted & Dismissal & Other & Unknown \\
\hline Gambling \& Lottery & 2 & 1 & & 1 \\
Narcotics & 4 & 3 & & 1 \\
Weapons & 2 & 2 & & \\
Robbery, Burglary \& Theft & 5 & 2 & 2 & 1 \\
Homicide, Rape \& Assault & $\mathbf{6}$ & $\frac{1}{9}$ & $\frac{3}{5}$ & $\frac{2}{5}$ \\
\cline { 2 - 5 } Totals & 19 & & 9
\end{tabular}

Source: Data furnished by Jean G. Taylor of the Institute for Defense Analyses in Letter of May 5, 1970.

75 The Chicago total is 650 motions in felonies and misdemeanors for 12 sample days, which is equivalent to 1140 for a month with 21 working days. The District's total is 35 per month for misdemeanors (Table 6) and an average of 12 per month for felonies (Table 7), for a total of 47 per month. Chicago reports 9 times more arrests under the Uniform Crime Reporting Program (classes 1 through 26) than the District. Chicago Police Annual Report, 1968, p. 17; Metropolitan Police Department Washington, D.C., Annual Report, Fiscal 1969, p. 43. 
in the receptivity of judges to claims of illegal search and seizure and differences in the structure of the system, as well as differences in police behavior. Comparative data cannot be evaluated accurately without taking account of these differences. The point is of enormous importance, especially where the researcher plans to use multiple area comparisons. It is important even for a proper evaluation of individual data such as the inference to be drawn from the high per cent of motions to suppress granted in. Chicago or the low per cent granted in the District. A short summary of the important systemic differences between those two cities is appropriate for illustrative purposes. ${ }^{76}$

In Chicago there is virtually no advance screening by the prosecutor. Felony and misdemeanor charges are specified by the police without review by the prosecutor until they come up for initial hearing in one of the municipal branches of the Circuit Court. Here there are numerous motions to suppress, dismissals, charge reductions and other rearrangements. The misdemeanors are tried on the merits. Preliminary hearings are held in the felonies, with bindovers going on to the grand jury and disposition before a judge in the Criminal Division. Motions to suppress are invariably made and disposed of in the municipal branch and there are rarely any such motions after felony indictments have gone on for trial or plea in the Criminal Division. (In 12 sample days in 1969 there were 649 motions to suppress in the municipal branches and only 1 in the Criminal Division. $)^{77}$ In this system, the occasions for invoking the exclusionary rule are litigated in open court, in advance of charge reductions or plea bargaining.

District of Columbia prosecutors review all cases before they are presented in court. A significant number of charges-10 per cent is the popular guess-are dropped ("no-papered") at this point for various reasons including the prosecutor's conclusion that vital evidence would be suppressed.88 No motions to suppress are heard at the

76. The account of Chicago's system is based on the author's experience, largely reported in D. OAks \& W. LeHMAN, supra note 73, at chs. 1-4. See also McIntyre, A Study of Judicial Dominance of the Charging Process, 59 J. Crim. L.C. \& P.S. 463 (1968). The District of Columbia information is based on H. SUbin, CRIMINal Justice IN a MetroPOLITAN COURT (Office of Criminal Justice, 1966) and on the author's observations and conferences with several prosecutors in that city.

77 See Table 3. If a motion to suppress is granted in the municipal branch, the evidence cannot be introduced in the Criminal Division. People ex rel. MacMillan v. Napoli, 35 III. 2d 80, 219 N.E.2d 489 (1966).

78 But cf. H. SUBIN, supra note 76, at 29-31, which shows no such reason among the classification of reasons for no-papering. For a discussion of this use of the exclusionary rule as a factor in the decision to charge, see F. Miller, Prosecution: The Decision to Charce a Suspect with a CRIME 37-40 (1969). 
first court appearance or at the trial of misdemeanor charges, or at the preliminary hearing of felonies. All felony motions are heard in the district court, after indictment. Misdemeanor motions are calendared and heard on notice not less than 5 days before trial. In this system many, if not most, of the occasions for invoking the exclusionary rule are eliminated by the prosecutor's advance screening. Consequently, the low proportion of cases with motions to suppress and the low proportion of motions granted are in no way indicative of the impact of illegal search and-seizure as a factor in the disposition of cases in the District. That impact would appear only in a study of the extent to which charges are no-papered by the prosecutor because of anticipated exclusion of vital evidence by a motion to suppress.

\section{Arrest and Conviction}

The relative accessibility of crime statistics has prompted their use in comparisons of crime before and after the adoption of the exclusionary rule. After California adopted the exclusionary rule in 1955, law enforcement personnel used a few arrest and conviction statistics to condemn the decision's supposed adverse effect upon law enforcement and the crime rate. Yale Kamisar effectively refuted these dire predictions, but made no attempt at a statistical evaluation of the theory that the exclusionary rule discouraged illegality by the police. ${ }^{79}$ If the exclusionary rule does affect police behavior, then this might be discernible in the rates of arrest or conviction. The totals for all crimes are not likely to be revealing, but the number and rate of arrests and convictions in selected offenses may provide evidence on the effect of the exclusionary rule.

Figures 1, 2 and 3 contain comparative annual figures on arrests and convictions in weapons, narcotics, and gambling offenses in Cincinnati over a period of five years before and six years after the adoption of the exclusionary rule. ${ }^{80}$ To provide added information for

70 Kamisar, Public Safety v. Individual Liberiies: Some "Facts" and "Theories," 53 J. Crim. L.C. \& P.S. 171, $188-90$ (1962); Kamisar, On the Tactics of Police-Prosecution Oriented Critics of the Courts, 49 CORNELl L.Q. 436, 462-7 (1964). Also effective as rebuttal but of no positive force in demonstrating the deterrent capacity of the exclusionary rule is the so-called "pragmatic evidence" Justice Stewart cites in Elkins v. United States, 364 U.S. $206,218(1960)$, that the federal courts have operated under the exclusionary rule for over half a century without disrupting the administration of criminal justice or rendering the F.B.I. ineffective.

80 These offenses were chosen because Table 3 shows them to be the crimes most likely to involve illegal enforcement activity. Cincinnati was chosen for illustrative purposes because its annual police reports for the period are extraordinarily thorough and detailed and apparently were kept on a consistent basis from year to year. Ohio is an excellent jurisdiction to test the effect of Mapp since $M a p p$ was a local case, and probably received as much publicity in Ohio law enforcement circles as in those of any state. 


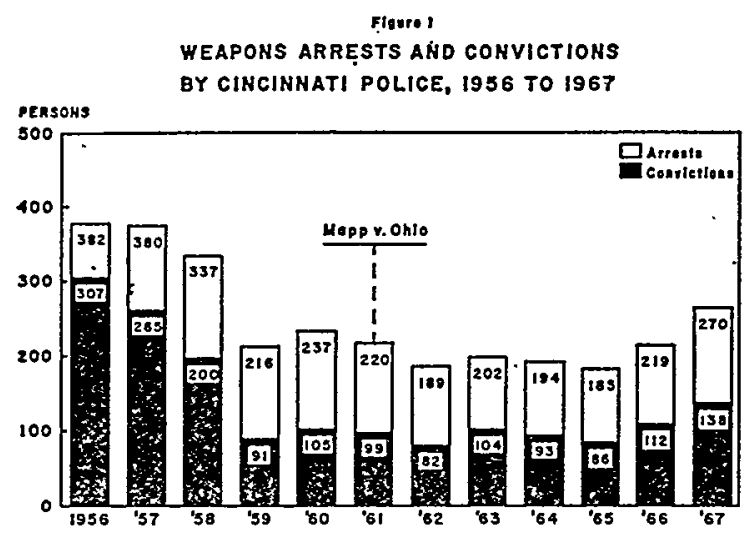

Weapons offenses include carrying and possession. In this and the next two Figures arrests equal total persons charged by police plus persons released by police without formal charges. Convictions are persons found or pleaded guilty, whether arrested in that year or the previous one.

Source: Cincinnati Police, Annual Report of the Division of Police, 1956 through 1967, Table 24. The assistance of University of Chicago Law School student, Katherine B. Soffer, in the assembling of data for Figures 1 through 5 is gratefully acknowledged.

interpretive purposes, Figures 4 and 5 show the number of gambling raids and the per cent of stolen property that was recovered in each year.

The implications of Figures 1 through 5 may be stated briefly. So far as concerns narcotics and weapons offenses in Cincinnati, the Mapp decision does not seem to have had any effect whatever on the number of arrests or upon the number or per cent of convictions. Some changes are evident over the 12-year period covered by the figures, but they bear no apparent relationship to the Mapp decision.

The number of gambling arrests and convictions is down sharply

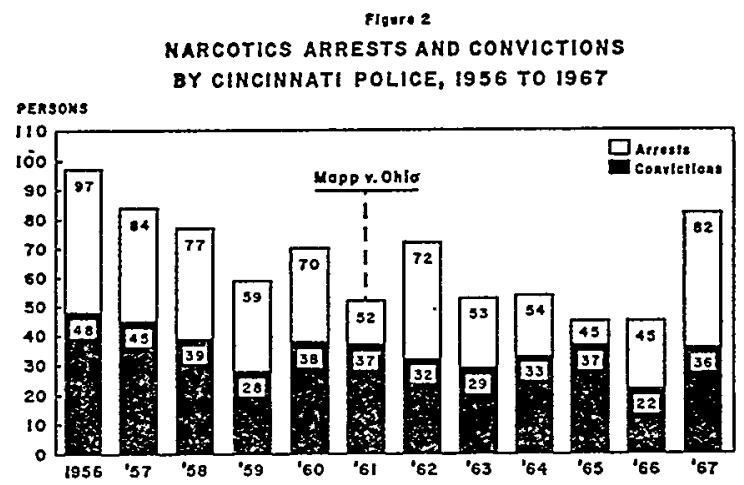

Source: Same as Figure 1. 
Figure 3

GAHBLING ARRESTS AND CONVICTIONS

BY CINCINNATI POLICE, 1956 TO 1967

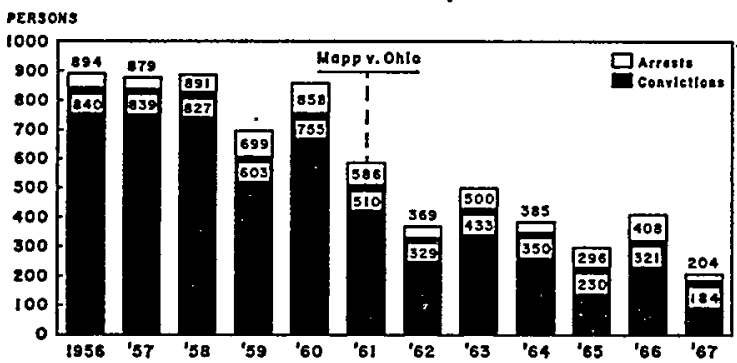

Source: Same as Figure 1.

from 1960, the year before Mapp, to 1961 and subsequent years. Thus, the average number of gambling convictions in the five years before Mapp was 771, compared with 308 , or less than half, in the six years after $M a p p$. That difference undoubtedly reflects significant changes in police behavior, which may have included closer adherence to constitutional standards of search and seizure. But Figure 4 suggests that the major factor was a consistent annual reduction in the number of "raids" that resulted in gambling arrests. Thus, there was an average of 242 raids per year in the five years before $M a p p$, and only 73 in the six years after. That difference might itself indicate an important conformity induced by the Mapp decision, but Figure 4 shows that the decreasing number of raids began in 1959, two years before the Mapp decision, and decreased consistently from year to year through 1962, with no apparent relationship to the 1961 Mapp decision.

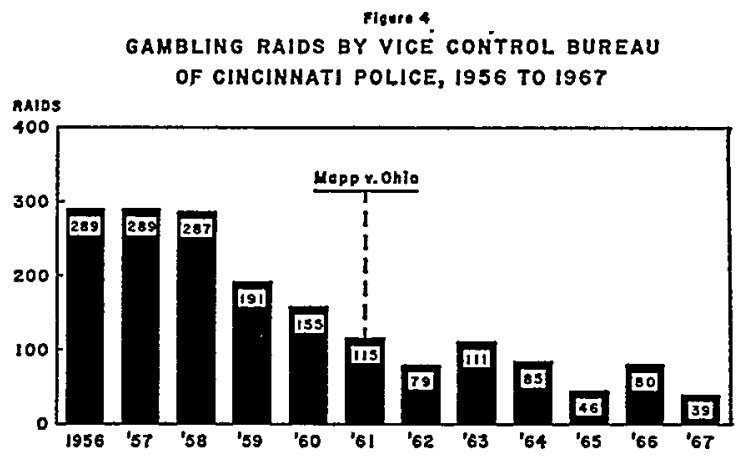

Consists of total raids on handbooks, policy, and lottery places, and dice and card games. Counts only raids where one or more arrests was made.

Source: Cincinnati Police, Annual Report of the Division of Police, 1956 through 1967, Table 130. 
Floures

PERCENT OF STOLEN PROPERTY RECOVERED

IN CINCINNATI AND TORONTO, 1956 TO 1967

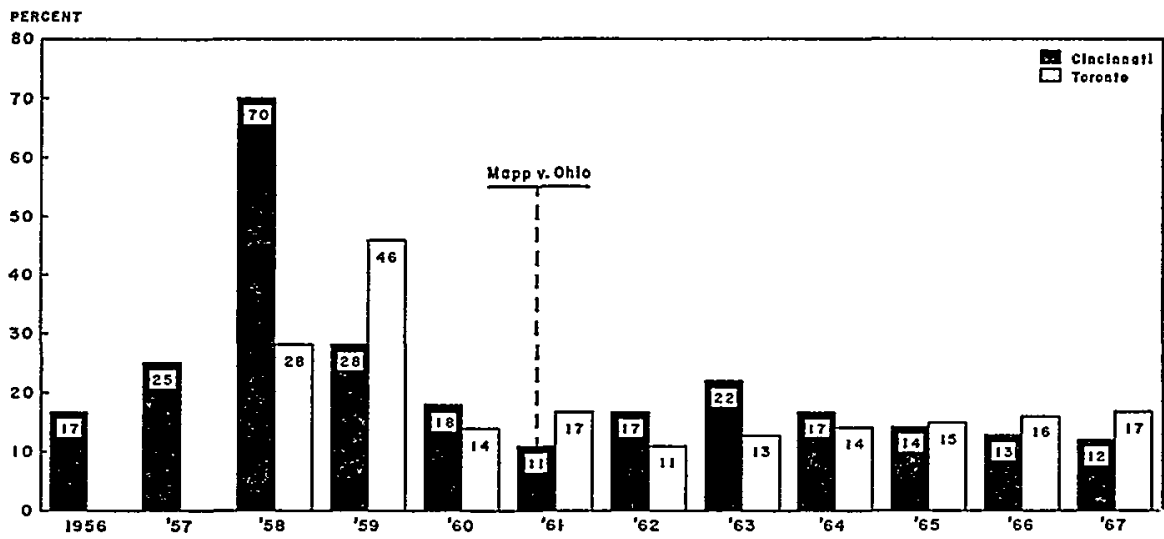

Excludes motor vehicles.

Source: Cincinnati Police, Annual Report of the Division of Police, 1956 through 1967, Table 96; Metropolitan Toronto Police Department Statistical Report, 1958 through 1967 (comparable figures unavailable for 1956-57), furnished by Inspector Aubrey V. Potter, Letter of May 20, 1970.

Figure 5, which shows the per cent of stolen property recovered, is included because police officers in various areas have advised the author that they frequently find it necessary to violate search and seizure rules in order to fulfill their paramount responsibility of recovering stolen property. If this is true, and if the exclusionary rule induces greater conformity to those rules, then adoption of the exclusionary rule should result in a decrease in the per cent of stolen property that is recovered. Figure 5 shows that no such decrease

Figari 6

SEIZURES OF KNIVES

BY CINCINNATI POLICE, 1960 TO 1962

(IN SIX-MONTH PERIODS)

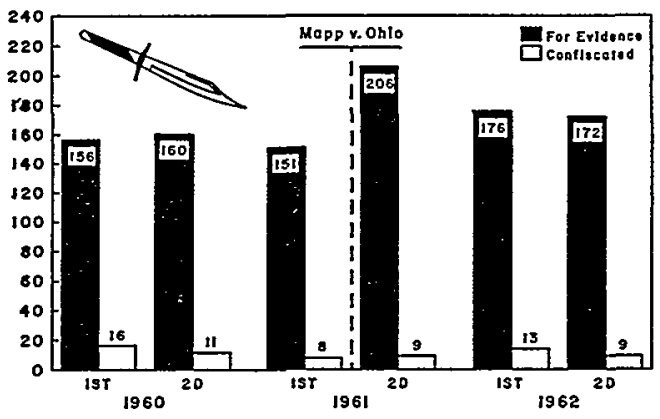

Source: Property Book, Cincinnati Police Department. Data compiled by University of Cincinnati Law School students Paul Nemann and Charles Johnson, whose assistance is gratefully acknowledged. 
occurred, at least not immediately. The fluctuations in recovery of stolen property by the Cincinnati police seem unrelated to the adoption of the exclusionary rule. ${ }^{81}$ For comparative purposes the figure also shows the per cent of recovery by the police in Toronto, Canada, where there is no exclusionary rule. During the six years 1962 through 1967, when Cincinnati had an exclusionary rule and Toronto did not, the percentages of stolen property recovered were approximately the same, with Toronto being higher in three years and Cincinnati being higher in three years. It may be significant that the Cincinnati percentage shows a consistent gradual decrease each year from 1963 through 1967, at the same time that Toronto's percentage consistently increased. This may reflect a long range effect of the Mapp decision, with decreased recoveries of stolen property as police officers begin to accept and conform to the search and seizure requirements. This evidence by itself is inconclusive, but it does provide some offset against Figures I through 3, which tend to indicate that the exclusionary rule had no effect on the number of arrests and convictions for weapons and narcotics offenses, and that important changes in gambling statistics were probably attributable to something other than the adoption of the exclusionary rule.

\section{Seizures of Property}

A more promising indirect measure of the extent of police conformity to search and seizure law is the amount of contraband or illegally possessed property seized by the police. If law enforcement officials conform more closely to the rules of search and seizure, then this may change the amount of property seized. Police departments generally keep records of such property. The property book kept by the Cincinnati police lists all property that has been seized and, fortunately for this study, even classifies it in two categories, property seized for use as evidence, and property confiscated without any intention to use it as evidence. ${ }^{82}$ Figures 6 through 11 summarize the amount of various types of property seized as evidence and confiscated by the Cincinnati police during each of the three six-month periods just before and just after the Mapp decision.

81 For example, the high per cent in 1958 was apparently attributable to the theft and recovery of an extraordinarily large quantity of currency. The currency figures for 1958 were $\$ 1,008,000$ stolen and $\$ 872,000$ recovered, compared with an average of $\$ 141,000$ and $\$ 18,000$ for the other four years in the period 1956-60.

82 Police officials advise that the property seized for use as evidence may be returned by permission of the officer or by order of the court. Property that is confiscated can be returned only by order of the Chief of Police. The custodian of the property had never heard of a civil action for return of confiscated property. 
Figure 7

SEIZURES OF HANDGUNS

BY GINGINNATI POLICE, 1960 TO 1962

(IN SIX-MONTH PERIODS)

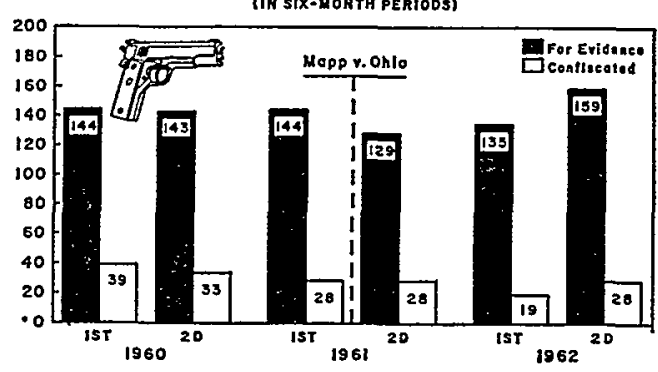

Source: Same as Figure 6.

The before-after comparisons of property seized by Cincinnati police shown in Figures 6 through 11 yield the following inferences concerning the effect of the exclusionary rule. The seizures of weapons (rifles and shotguns, handguns, and knives) either for evidence in court or by way of outright confiscation were essentially unchanged during the period from 1960 through 1962. The same was true of narcotics seized for use as evidence. There was no apparent change in enforcement results in either area following the Mapp decision.

Figures 10 and 11 show that there were marked decreases in the quantity of gambling apparatus seized after the Mapp decision. Thus, the average number of seizures of policy and bookmaking articles dropped from 43 to 25 in the three six-month periods before and after $M a p p$, a reduction of 42 per cent. Similarly, the average number of seizures of cards and dice for use as evidence was down from 81 to 48 ,

Flaure

SEIZURES OF RIFLES AND SHOTGUNS QY CINCINNATI POLICE, 1960 TO 1962 (IH SIX-MONTH PERIODS)

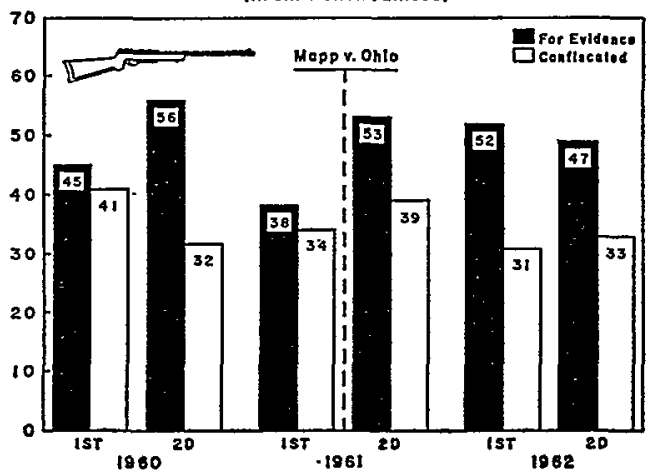

Source: Same as Figure 6. 
Floure?

SEIZURES OF NARCOTICS

BY CINGINNATI POLICE, 1960 TO 1962

(IN SIX-HONTH PERIOOS)

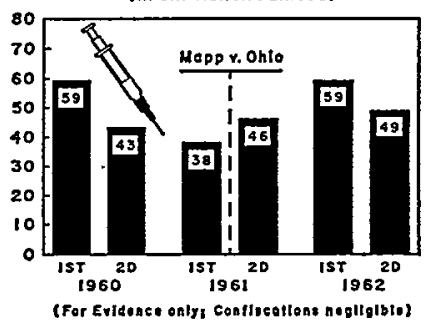

Source: Same as Figure 6.

a reduction of 41 per cent. The average number of confiscations of cards and dice was down from 127 to 23, a reduction of 82 per cent, but in this instance the reduction seems to follow a trend that commenced before the Mapp decision.

The sharp reductions in gambling seizures must be considered in light of the figures on gambling raids, set out in Figure 4. The number of raids showed consistent decreases in this period, with 1961 down 25 per cent from 1960, and 1962 down an additional 31 per cent from 1961. If the 1961 raids are divided equally between 1960 and 1962 to obtain an eighteen-month figure for comparative purposes, then the average number of raids in the three six-month periods after Mapp was just 36 per cent lower than the average for the similar periods before. This reduction is comparable to and is a probable explanation of the 41 and 42 per cent reduction in the quantity of gambling articles seized for use as evidence. If the number of raids does explain the decrease in seizures, then the change probably is not attributable

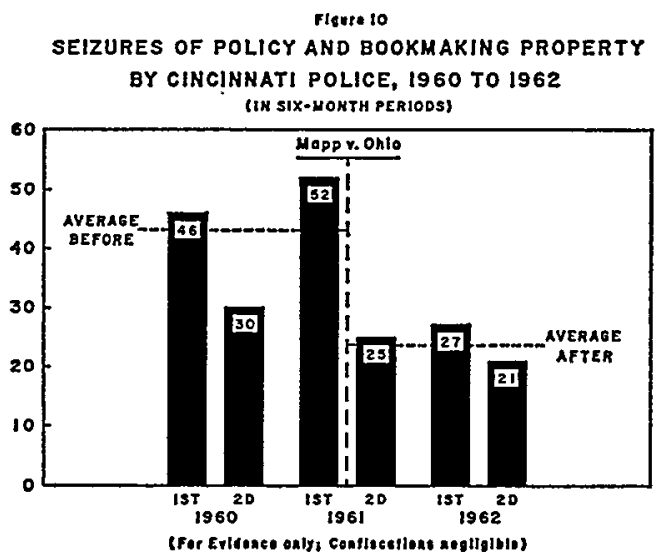

Source: Same as Figure 6. 
(IN SIX-MONTH PERIODS)

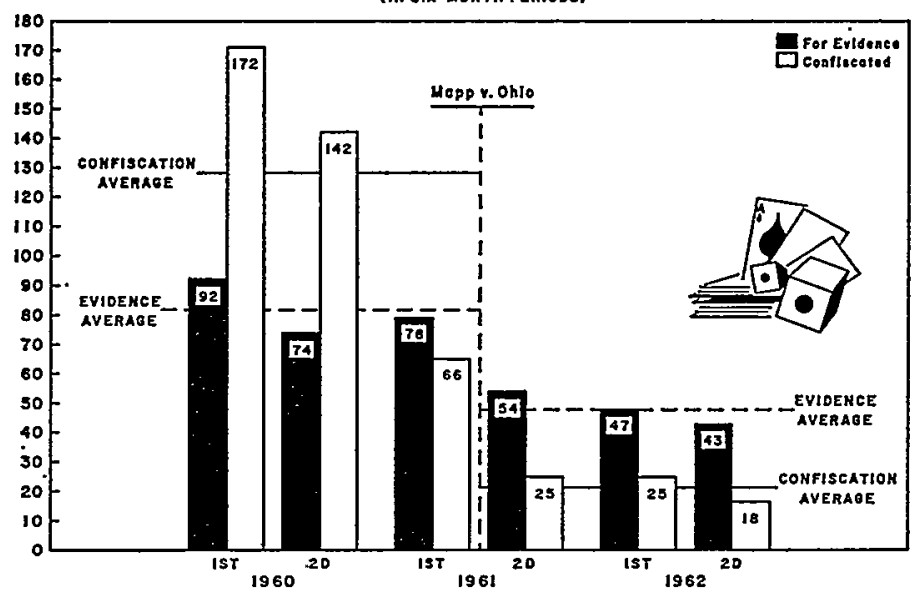

Source: Same as Figure 6.

to the adoption of the exclusionary rule, since Figure 4 shows that the annual decreases in raids began well before the Mapp decision.

The 36 per cent decrease in the number of raids in this period may not account for the 82 per cent reduction in the quantity of cards and dice confiscated. Another cause must be sought, and the adoption of the exclusionary rule is a distinct possibility. Decreased confiscations is one of the first effects to be expected if law enforcement officials conform more closely to the rules of search and seizure in the gambling area. The difficulty with this explanation is the fact, apparent from an examination of Figure 11, that the decreased number of confiscations is largely, if not exclusively, expressive of a trend that began before the Mapp decision. Firm conclusions on this point must await comparison of the number of seizures over a longer period of time.

\section{E. Police Reports on the Reasons for Arrests}

The most significant empirical study of the effects of the exclusionary rule published after the $M a p p$ case was the work of law students. It also used a before-after comparison. To determine the effect of Mapp on police practices in New York City, Columbia Law School students analyzed the evidentiary grounds for arrest and subsequent disposition of misdemeanor narcotics cases in New York City before and after the Mapp decision. The evidentiary grounds were determined from the facts of arrest reported by the arresting officer and recorded on 
documents in the case files in the criminal courts. The students obtained this information for all misdemeanor narcotics cases reported in six months from September through March, 1960-61 (just before $M a p p$ ) and the same six-month period 1961-62 (just after Mapp). Because they concluded that the type of police assignment might influence the response to $M a p p$, they classified the arrest data separately for Narcotics Bureau, Uniform Division, and Plainclothes Detail. The number of arrests by each group is shown in Table $8 .{ }^{83}$

TABLE 8

MisdemeANor NARCotics ARRESTS by

New York City Police, 1960-62

\begin{tabular}{lccc}
\hline & \multicolumn{2}{c}{ Six-month period } & \\
\cline { 2 - 3 } Job Assignment & Before Mapp & After Mapp & Difference \\
\hline Narcotics Bureau & 1468 & 726 & $-51 \%$ \\
Uniform Division & 316 & 330 & $+4 \%$ \\
Plainclothes Detail & $\underline{507}$ & $\underline{625}$ & $+23 \%$ \\
Total & $\overline{2291}$ & $\overline{1681}$ & $\overline{-27 \%}$ \\
\hline
\end{tabular}

The student authors felt that the sharp reduction in the number of Narcotics Bureau arrests after the $M a p p$ case supported the proposition "that more than 50 per cent of the Bureau's pre-Mapp arrests were the result of searches and seizures in violation of the fourth amendment, and that its post-Mapp arrests were legal."84 As to pre-Mapp arrests, these figures give some evidence of illegality, but the evidence is inconclusive. As to the legality of post-Mapp arrests, the figures give no support whatever to the conclusion.

Of greater interest are the summaries in Table 9 of the officers' accounts of how the evidence for the arrest was discovered.85

The student authors suggest that the 32 percentage point decrease in Narcotics Bureau "hidden on person" allegations after Mapp shows that the pre-Mapp figure contained a large proportion of unconstitutional searches and seizures. This conclusion is said to be supported by the similar decreases in the proportion of hidden on person allegations by uniform and plainclothes officers (22 and 20 percentage points). The corresponding increase in allegations by uniform and

83 Comment, Effect of Mapp v. Ohio on Police Search-and-Seizure Practices in Narcotics Cases, 4 Colum. J.L. \& Soctal Prob. 87, 92 (1968). The trends in the table were confirmed by samples of 100 cases in February, 1964 and February, 1966.

84 Id. The authors suggested that the Bureau's arrest rate declined sharply (while the uniform and plainclothes rates remained relatively constant) because the Bureau is a small, close-knit organization subject to rapid re-education and command influence.

85 Id. at 94 . 
TABLE 9

NEW YoRk CrTy POLICE OfFicers' ALlegations

REgarding Discovery OF Evidence in

MisdemeANor Narcotics OFFenses, 1960-62

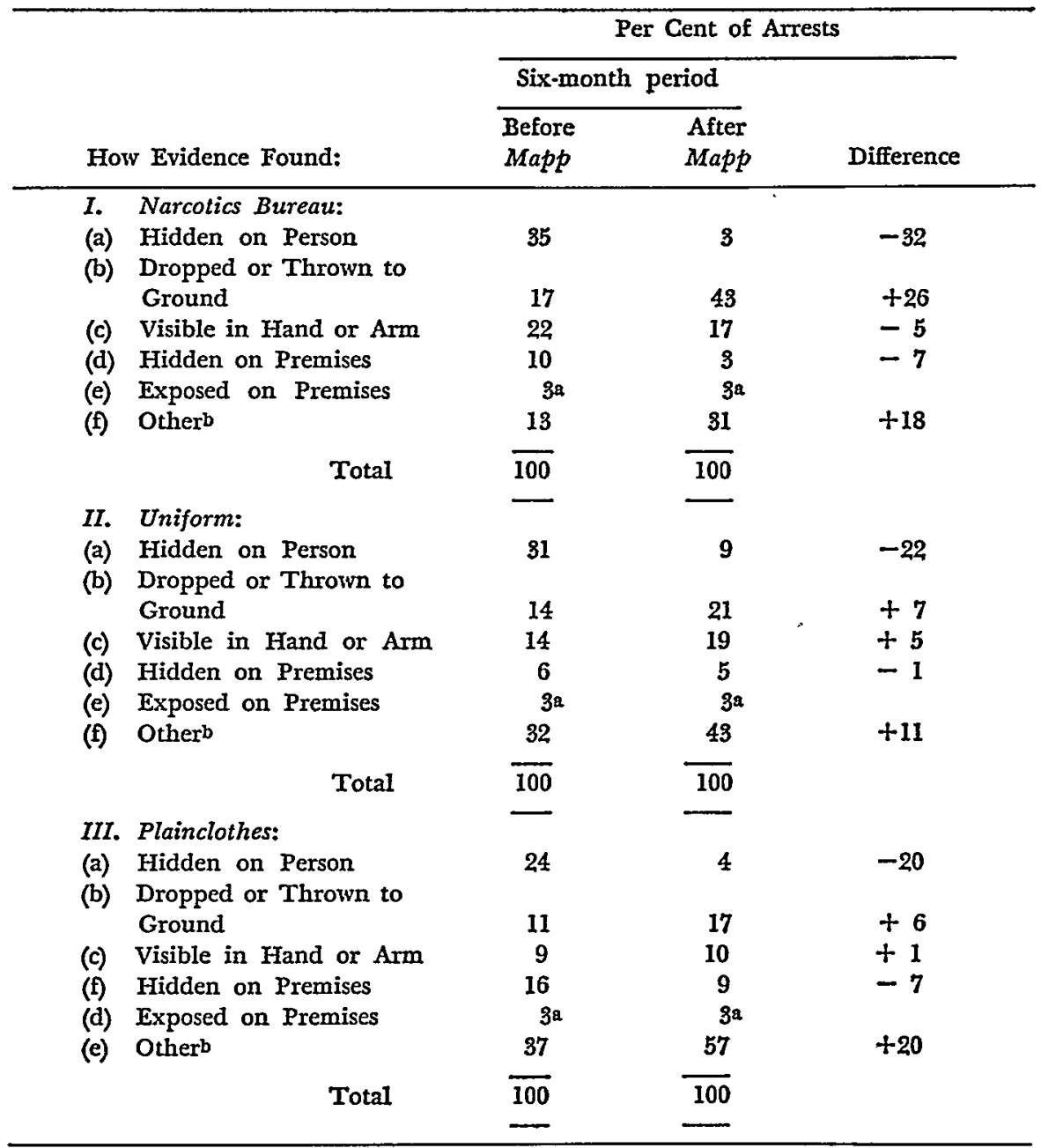

a This is approximate. The table shows "less than 5\%."

b The article gives no explanation of what allegations (if any) account for this "other" category. The amount shown is approximate, within two percentage points.

plainclothes officers that defendant dropped the contraband to the ground (so-called "dropsie" testimony) or had it "visible in hand" is notable for the fact that this kind of testimony fits the probable cause requirements of $M a p p .{ }^{86}$ As to uniformed officers, the comment urges

86 The increase from $17 \%$ to $43 \%$ in the proportion of "dropsie" arrests by Narcotics Bureau officers was not thought significant, because the number of dropsie arrests by Bureau officers remained essentially constant before and after Mapp. The per cent of 
that the sharp increases in the number and per cent of "dropped or thrown" and "in hand" arrests (the total of these two categories was $28 \%$ before $M a p p$ and $40 \%$ just after) "render the veracity of complaining uniform officers subject to question." 87 The student authors conclude:

Table [9] supports the conclusion that uniform police have been fabricating grounds of arrest in narcotics cases in order to circumvent the requirements of Mapp. Without knowledge of the results of this study, the two Criminal Court judges and the two Assistant District Attorneys interviewed doubted that a substantial reform of police practices in narcotics had occurred since Mapp. Rather, they believe that police officers are fabricating evidence to avoid Mapp. ${ }^{88}$

Viewing the same phenomenon of the sharp increase after Mapp in the proportion of New York City police officers testifying that they had seen the defendant throw narcotics to the ground as the officer approached, both Richard Kuh and Irving Younger reached the same conclusion, that after the $M a p p$ case there was an increase in police perjury designed to legalize an arrest and thus avoid the effect of the exclusionary rule. ${ }^{89}$ But some police and prosecutors have given the author an alternative and legal explanation for the observed increase in the "dropped or thrown" and "in hand" grounds for arrest..0

dropsie arrests increased because the total number of Narcotics Bureau arrests was cut in half in this period. $I d$. at 95 . (See Table 8.)

$87 \mathrm{Id}$.

$88 \mathrm{ld}$. at 95-96. This Columbia study is a resourceful and imaginative attempt to obtain an indirect measure of the effect of adoption of the exclusionary rule. The principal methodological difficulty is that most police departments apparently do not require such reasons to be recorded, and even where this is done the records may not be available this long after the Mapp decision. The author approached several metropolitan police departments to try to obtain data to replicate the Columbia study, and was not able to find any department where the data was available. A further difficulty of interpreting such data-common to data obtained in other indirect tests-is discussed in text accompanying note 136 infra.

89 Kuh, The Mapp Case One Year After: An Appraisal of its Impact in New York, 148 N.Y.L.J. 4 n.2 (1962); Younger, Constitutional Protection on Search and Seizure Dead, 3 Trial 41 (Aug.-Sept. 1967), both quoted in F. Remington, D. NEwMaN, E. KIMBall, M. Melli \& H. Goldstein, Griminat Justice Administration 261-2, $272-3$ (1969).

90 A person in possession of narcotics who sees a policeman approaching has a dilemma that grows out of the exclusionary rule. If the officer has a warrant for his arrest, the narcotics will be discovered and usable as evidence unless he can discard them. If the officer has no warrant, then the person should retain the narcotics since any search necessary to discover them will probably be illegal and the exclusionary rule will prevent their use in evidence. Knowing the difficulty that an uncertain possessor will have in resolving this dilemma, a police officer without a warrant may rush a suspect, hoping to produce a panic in which the person will visibly discard the narcotics and give the 


\section{F. Observations of Police Behavior}

Detailed observation of police behavior has also yielded valuable insights into the effect of the exclusionary rule. Jerome H. Skolnick's notable book, Justice Without Trial, ${ }^{91}$ is the most fruitful source of information obtained by this technique. Over a period of fifteen months in 1962 and 1963, Skolnick carried out many weeks of intensive "participant observation" of the operations of the police of an unidentified city of 400,000 . This included two weeks with police of the patrol division, six weeks direct observation of the vice control squad, four weeks with the burglary squad, and two weeks with the robbery and homicide detail. Skolnick's observations of the effect of the exclusionary rule on the police of this city may be summarized as follows:

(1) The exclusionary rule was "neutralized" in practice.

(2) The police viewed the rule not as guaranteeing greater protection of the freedom of decent citizens, but as unnecessarily complicating the task of detecting and apprehending criminals.

(3) Because the policeman's allegiance was to the police organization and to its network of professional responsibilities and evaluative standards, he did not respond to judicial interpretations of legality.

(4) The police organization interpreted its fundamental duty as the discovery of criminal activity. Remaining within the boundaries of the law was secondary. Consequently, when the police felt that the arrest and search and seizure rules constituted too great a hindrance to the apprehension and conviction of criminals, they would "reconstruct a set of complex happenings in such a way that, subsequent to the arrest, probable cause can be found according to appellate court standards." In this way, "the policeman fabricates probable cause." 92

(5) "The policeman, as a tactical matter, recognizes an obligation to appear to be obeying the letter of procedural law, while often disregarding its spirit. Thus, the working philosophy of the police has the end justifying the means; according to this philosophy, the demands of apprehension require violation of procedural rules in the name of the higher justification of reducing criminality." ${ }^{3}$

officer cause to arrest him and a legitimate ground to use the evidence. It is said that an increased use of this police tactic could explain the changes shown in Table 9.

$91 \mathrm{~J}$. Skolnick, Justice Without Trial (1967).

92 Id. at 215.

98 Id. at 228. 
(6) "Since in the policeman's hierarchy of values, arrest and subsequent conviction are more important the 'bigger' the 'pinch,' compliance with the exclusionary rule seems contingent upon this factor." 94

Although it too lacks quantitative data, Wayne LaFave's 1956-57 American Bar Foundation field study of arrest practices in Kansas, Michigan and Wisconsin also contains relevant impressions on the exclusionary rule.95 Like Skolnick, he observed the police tendency to rely on departmental rather than legal norms of behavior:

Even when the law is explicit, the legal norms governing police behavior are seldom communicated to the officer on the beat. . . . Consequently, the average police officer is less influenced by his knowledge of the legal standards than by his observations of how more experienced officers react in such situations. ${ }^{96}$

LaFave observes that "[i]t is apparent that the exclusionary rule is not a deterrent to improper police practices in situations where the police have no desire to prosecute and convict the person who is arrested." $97 \mathrm{He}$ also states that there were some communities where the police could hardly have been affected by court decisions on the proper procedures for arrest and search because they were totally unaware of them..$^{98}$ But LaFave concludes that " $[t]$ he exclusionary rule has contributed to an increased awareness by police of constitutional requirements," in part by giving courts and legislatures the occasion and incentive to articulate them. ${ }^{99}$

\section{G. Canadian Comparison}

The final source of empirical information about the effect of the exclusionary rule is principally a suggestion for research rather than a collection of available data. It would be instructive to compare the degree of police adherence to search and seizure rules in comparable jurisdictions with and without the exclusionary rule. Now that the Mapp case requires all states to apply the exclusionary rule, it is necessary to go outside this country for current comparisons. An obvious choice is Canada, which has no rule excluding illegally obtained evi-

$84 I d$.

95 W. LAFAvE, supra note 34 .

$96 \mathrm{Id}$. at 210-1. This passage appears in the context of a discussion about the degree of force to use in making an arrest.

97 Id. at 488.

$88 \mathrm{Id}$. at 505 .

$99 \mathrm{Id}$. at $504-5$. 
dence. ${ }^{100}$ Toronto would be a suitable city for comparison. ${ }^{101}$ A study could attempt to determine whether Toronto police adhere to their local search and seizure rules as completely as police officers in a comparable United States city, and, if so, what factors are responsible for that adherence,

Even without conducting such an empirical study, it is instructive to ask how the Canadians manage to discourage illegal behavior by law enforcement officials without resort to the exclusionary rule that is apparently considered so essential on this side of the border. A superficial comparison suggests several factors of potential importance. ${ }^{102}$ A brief description of course risks oversimplifying a complicated comparison. Being in large part matters of fact, the suggested factors should themselves be the subject of factual inquiry. They are set out here as an invitation to that inquiry.

To begin with, police discipline is relatively common and is said to be seriously pursued in Canada, at least in Toronto. ${ }^{103}$ Second,

100 The Canadian search and seizure law is discussed in Parker, The Extraordinary Power to Search and Seize and the Writ of Assistance, I U.B.C.L. REv. 688 (1963); Weiler, The Control of Police Arrest Practices: Reflections of a Tort Lawyer, Studues IN Canadian TORT LAw 416-69 (Linden ed. 1968). Briefer treatments appear in Groom, The Admis. sibility of Evidence Illegally Obtained, 13 GHITry's L.J. 54 (1964); Clendenning, Police Power and Civil Liberties, 4 Osgoode Hall L.J. 174 (1966); Martin, supra note 15.

The leading English case is Kuruma v. The Queen, [1955] A.C. 197, 204, which gives a judge "discretion to disallow evidence if the strict rules of admissibility would operate unfairly against an accused." The Ontario Court of Appeal recently carried that precedent as far as it had been carried in Canada in sustaining a trial judge who had exercised his discretion to exclude part of a confession from evidence upon being shown that it had been procured by trickery, duress and improper inducements. The opinion reasoned that "a trial Judge has a discretion to reject evidence, even of substantial weight, if he considers that its admission would be unjust or unfair to the accused or calculated to bring the administration of justice into disrepute ...." Regina v. Wray, [1970] 2 Ont. 3, 4. That reasoning was rejected and the judgment was reversed by the Supreme Court of Canada. The Queen v. Wray, June 26, 1970 (not yet reported). The opinions give very narrow scope to the judge's right to reject evidence that would "operate unfairly against the accused," and clearly exclude considerations such as the manner in which the evidence was obtained.

101 With a city population of about 700,000 in a metropolitan area of about 2 million, Toronto's size characteristics are comparable to Pittsburgh, St. Louis, Washington, D.C., and Cleveland. And in comparison with other sizable Canadian cities, Toronto is probably most like a United States city in the racial and ethnic diversity of its population.

102 In addition to cited authorities, observations about Toronto and Canadian law are based upon information obtained during the author's brief conferences with police officials, prosecutors and a judge in Toronto. The author is specially indebted to Ian Cartwright, Crown Counsel in Toronto, for helpful suggestions on this section.

103 A comparison of disciplinary actions against Toronto and Chicago police is equivocal on whether Toronto is extraordinarily diligent. 
police officers are occasionally prosecuted for criminal misconduct occurring in the course of their official duties.

Of paramount importance in the control of law enforcement behavior in Canada is the fact that an aggrieved person's tort cause of action against an offending police officer is a real rather than just a theoretical remedy. A Toronto lawyer has observed that

the remedy in tort has proved reasonably effective; Canadian juries are quick to resent illegal activity on the part of the police and to express that resentment by a proportionate judgment for damages. ${ }^{104}$

The prospect of tort liability is sufficiently real that some provincial statutes give judges authority to grant law enforcement officials immunity against civil proceedings in individual cases, but this authority is not routinely exercised. ${ }^{105}$ An Ontario statute makes the chief constable of a municipal police force and the commissioner of the provincial police personally liable for the torts committed by members

\begin{tabular}{|c|c|c|}
\hline \multicolumn{3}{|c|}{ Disposition of Complaints Against Police Officers } \\
\hline $\begin{array}{l}\text { Total sworn personnel (excludes civilian } \\
\text { as crossing guards) }\end{array}$ & 11,928 & 3,347 \\
\hline Complaints handled & 5,323 & 347 \\
\hline Complaints found valid & 1,128 & 105 \\
\hline Disposition of offending officer: & & \\
\hline Resigned & 98 & $\mathbf{5}$ \\
\hline Dismissed & 27 & 0 \\
\hline Reduced in rank & $\mathbf{0}$ & 1 \\
\hline Suspended for period or lost days off & 887 & $\mathbf{3}$ \\
\hline Reprimanded & 115 & 16 \\
\hline Admonished and counselled & 79 & 80 \\
\hline Total & 1,206 & 105 \\
\hline
\end{tabular}

Source: Annual Report of the Chief of Police of the Metropolitan Toronto Police Department, 1969, Schedule C. The Chicago Police Department does not release statistical information on the disposition of complaints. The Chicago figures are those compiled and published by The Chicago Tribune, Oct. 7, 1969, at 2.

104 Martin, supra note 15, at 272. Illustrative cases are Lamb v. Benoit, I7 D.L.R.2d 369 (Can. Sup. Ct. 1959) (\$2,500 false arrest damages for two days confinement without cause); Koechlin v. Waugh and Hamilton, 11 D.L.R.2d 447 (Ont. Ct. App. 1957).

A former Canadian police officer has written the following about arrest practices: "Based on my experience, and also conversations with police officers, most officers stay within the powers given to them. Only in rare circumstances will this power be exceeded, primarily because excesses are very easily proven, thus leaving the officer open to attack." Clendenning, supra note 100 , at 185 . This author identifies the most frequent abuse as the search of a vehicle believed to contain stolen goods.

105 Re Yoner, 7 D.L.R.3d 185 (Sup. Ct. Brit. Col. 1969). 
of their force in the performance or purported performance of their duties. ${ }^{106}$ The prominence of the tort remedy is such that one Canadian scholar has observed that "the task of controlling police practices, especially in the making of an arrest, historically has been performed by the institution of tort law, with relatively little help from the rest of the legal system." 107

The standard for police behavior and the manner in which this issue is brought before Canadian courts in tort and other proceedings is of interest. Canada has no written law comparable to the fourth amendment prohibition against unreasonable searches and seizures. The Canadian Parliament enacted a bill of rights in $1960,{ }^{108}$ but it contains no provision on this subject. The law protecting a Canadian citizen against police misconduct is the common law, which provides remedies for invasions of personal and property rights unless the offender is able to furnish some justification for his action. A person aggrieved by an illegal search and seizure that located incriminating evidence cannot have the evidence excluded or obtain other relief in the criminal prosecution, so he has the burden of going forward to seek relief in another proceeding.

Two types of proceedings, both initiated by the aggrieved party, provide the principal occasions for Canadian courts to issue rulings on the propriety of police behavior. The first is a motion for an order in lieu of a writ of certiorari to quash a search warrant. This remedy challenges the sufficiency of a warrant or of the "information" on which the warrant was issued. If the motion is granted the judge will, inter alia, order the return of the articles seized under the warrant, thus preventing their use as evidence. ${ }^{109}$ However, if he still needs them as evidence the peace officer can immediately repeat the procedure, correctly, and seize the articles a second time. The scope of the motion to quash is further limited by the fact that it is only available to chal-

106 ONT. Rev. STAT. c. 99, § 23; c. 118, § 43a (1960).

107 Weiler, supra note 100 , at 419 . Weiler criticizes the tort remedy and advocates strengthening internal police discipline.

108 Can. Stat. c. 44 (1960).

109 Certiorari was the common law remedy to quash a search warrant. Rex v. Kehr, 11 Ont. 517 (1906); Re Yoner, 7 D.L.R.3d 185 (Sup. Ct. Brit. Col. 1969). In Ontario that remedy has been replaced by a statutory motion to quash. ONT. REv. STAT. c. 197, § 66 (1960); Worrall v. Swan and Sawatzky, [1965] 1 Ont. 527. The Worrall case might even be read to suggest that under this statute the judge could quash a conviction obtained by the improperly obtained evidence.

For a discussion of legal standards for the sufficiency of a warrant or information, and for numerous cases involving attempts to quash warrants, see Parker, supra note 100, at 696-702; Crankshaw's Criminal Code of Canada \$\$ 429-48, at 589-613 (7th ed. Popple 1959). 
lenge official action under a warrant, whereas a great majority of police arrests (and accompanying searches of the accused's person) are made without a warrant. ${ }^{110}$

The second and more comprehensive occasion for ruling on the propriety of police behavior is in a tort action, such as trespass or false imprisonment, in which the defendant officer attempts to justify his conduct under some common law rule or some act of Parliament or provincial legislation that protects him from civil liability. The principal federal statute in this area is section 25 of the Canadian Criminal Code, which provides that a person required or authorized by law to do anything in the administration or enforcement of the law "is, if he acts on reasonable and probable grounds, justified in doing what he is required or authorized to do and in using as much force as is necessary for that purpose." 111 The word "justified" means that the official has a defense against liability if he acts on "reasonable and probable grounds." The defense is clear as to criminal liability, and some authorities have even applied the Code to absolve defendants from civil liability, although there are substantial doubts about its validity in this application. ${ }^{112}$ In any case, an officer who has acted reasonably can count on a common law defense against liability for damages. In order to resolve the applicability of the defense in the damage action the court must consider and rule upon the meaning of the statutes and common laws relating to arrests and search and seizure. ${ }^{113}$

Another possible factor in the control of Canadian police, difficult

$110 \mathrm{It}$ is said that more than $90 \%$ of the arrests in Metro Toronto are made without a warrant. Weiler, supra note 100 , at 430 n.28.

111 Can. Stat. c. 51, § 25 (1953-54).

112 Crankshaw's Criminal Code of Canada $\$ \S 434-5$, at 598 (7th ed. Popple 1959). For cases in which an action against a police officer for assault or false imprisonment was dismissed on the ground that the officer had acted "on reasonable and probable grounds" and thus was free from civil liability, see Reid v. DeGroot and Brown, 42 Can. Crim. 252 (Sup. Ct. Nova Scotia en banc 1964); Pedersen v. Hansen and Reid, 2 Can. Crim. Cas. Ann. 348 (Sup. Ct. Brit. Col. 1963); Kennedy v. Tomlinson, 126 Can. Crim. Cas. Ann. 175 (Ont. Ct. App. 1959).

There is a problem of federalism in this use of the Criminal Code to provide a defense in an action of tort. The British North America Act of 1867, 30 Vict., c. 3, §§ 91-92, 6 CAN. Rev. Stat. (1952), gives the federal (Dominion) Parliament exclusive authority in criminal law and procedure, but gives the provincial legislatures exclusive authority over property and civil rights and all matters of a merely local or private nature. See generally Leigh, The Supreme Court and the Canadian Constitution, 2 OrT. L. Rev. 320, 329-36 (1968). Some Canadian lawyers have suggested that this division of power makes $\S 25$ of the Criminal Code ultra vires because the Dominion has no right to absolve a peace officer from a civil wrong.

113 Can. Rev. Stat. c. 51, §§ 96, 425-48 (1952); cases cited and discussed in Crankshaw's Criminal. Code of CaNADA $\$ \S 425-48$, at 588-613. 
to isolate but of great potential importance, is their tendency to obey the rules, irrespective of sanctions. Toronto police officials, prosecutors and a judge all insisted that their police are greatly concerned about obeying the rules and very sensitive to and quick to be influenced by judicial criticism of their conduct. It is doubtful that comparable United States officials would similarly describe the attitudes of their police.

As a final factor of control, the attitude and authority of Canadian prosecutors may be different from those of their United States counterparts. Experienced Toronto prosecutors advised the author that a prosecutor will sometimes exercise what he considers to be his teaching function with the police by refusing to introduce evidence that he considers to have been improperly obtained. Police officers are said to take such refusals very seriously and to modify their conduct in response to them. As a related and additional difference, Canadian prosecutors are part of the Ministry of Justice, which has direct or indirect command authority over most of the police organizations whose members engage in the conduct that prosecutors criticize. Consequently, if police arrest or search and seizure practices are offensive to a prosecutor, he has channels available to have them corrected. This is significantly different from the independent character of most United States prosecutors and police organizations, neither of which is in a position to bring any direct command influence on the other.

\section{H. Summary of Findings}

The empirical research previously published and the additional data set out here may be summarized as follows:

(1) More than half of the motions to suppress in the District of Columbia and Chicago concerned narcotics and weapons offenses. Most of the remaining motions were in one other crime category, gambling in Chicago and offenses against property in the District. This is persuasive evidence that the search and seizure practices that are supposed to be affected by the exclusionary rule are concentrated in the enforcement of these few crimes. ${ }^{114}$

(2) In 1969 about 45 per cent of all persons charged with gambling offenses in Chicago were being dismissed after granting of a motion to suppress evidence obtained by an illegal search and seizure. The comparable figure was 33 per cent for narcotics offenses and 24 per cent for carrying a concealed weapon. These figures show that illegal searches and seizures were commonplace in the enforcement of gambling, narcotics and weapons offenses by the Chicago police. They also 
provide evidence that the exclusionary rule does not deter the Chicago police from making illegal searches and seizures in a large proportion of the cases that come to court in these crime areas. ${ }^{115}$

(3) Comparisons of law enforcement statistics in various areas can be misleading because of differences in the criminal justice systems of cities and states. Thus, the extremely low proportion of District of Columbia defendants who are dismissed after the granting of a motion to suppress is equivocal on the extent of illegal searches and seizures in that area, since District prosecutors exercise a screening function and withhold filing some cases where the evidence is likely to be suppressed.116

(4) An examination of twelve years' statistics on law enforcement in Cincinnati shows:

(a) that the adoption of the exclusionary rule had no apparent effect upon the number of arrests or convictions in narcotics, weapons or gambling offenses; and

(b) that the adoption of the exclusionary rule had no immediate effect on the per cent of stolen property recovered, but there was a gradual decrease commencing several years after the Mapp decision.

These facts stand as some evidence that the adoption of the exclusionary rule did not work a significant change in Cincinnati search and seizure practices in narcotics, weapons or gambling offenses, but it may have had a slight long range effect of inducing greater conformity in searches for stolen property. ${ }^{117}$

(5) An examination of the quantity of property seized by the Cincinnati police during eighteen-month periods immediately before and after the $M a p p$ decision showed no change in the seizures of weapons or narcotics, but sharp decreases in the seizures of gambling apparatus. Some or all of the decrease in gambling seizures could be explained in terms of changes in law enforcement techniques that began two years before the Mapp decision, but the adoption of the exclusionary rule was also a possible cause. This data on property seizures furnishes further evidence that adoption of the exclusionary rule made no significant change in Cincinnati search and seizure practices in narcotics and weapons cases, but it suggests a possible effect in gambling. ${ }^{118}$ 
(6) In Canada, improper police behavior is controlled by internal police discipline, by command control that is partly responsive to the prosecutor, and by a relatively effective tort remedy. ${ }^{119}$

(7) Though clearly insufficient to justify a firm conclusion on the matter, there is some evidence that:

(a) Police training in search and seizure rules is more extensive where there is an exclusionary rule; ${ }^{120}$

(b) Police adherence to legality in searches was thought to have increased generally after the Mapp decision, with the proportion of perceived increase in states that $M a p p$ had forced to adopt the exclusionary rule being larger than the increase in states that had the rule all along;

(c) Police effectiveness in searches was perceived to have decreased more in states that had just adopted the exclusionary rule than in states that had the rule before $M a p p .{ }^{121}$

(8) Shortly after the Mapp decision, the proportion of uniformed New York City police officers who reported "narcotics in plain view" as the evidentiary ground for arrest in misdemeanor narcotics offenses more than doubled. This furnishes some evidence that the police were fabricating testimony in order to comply with arrest formalities and circumvent the exclusionary rule. ${ }^{122}$

(9) Scholars who have made sustained observations of police operations have reached the following conclusions:

(a) The exclusionary rule has contributed to an increased awareness of constitutional requirements by the police.

(b) The exclusionary rule will not affect police practices where the police have no desire to prosecute.

(c) The effectiveness of the exclusionary rule as a control upon police behavior varies in direct proportion to the seriousness of the crime.

(d) In general, and especially for less serious crimes, the most important determinants of police behavior are the institutional values of the police department, which set a higher value on the prevention of crime and apprehension of the criminal than upon adherence to legal "technicalities" concerning police behavior. Consequently, the police will conform their testimony to the 
content necessary to avoid these "procedural" barriers and to assure accomplishment of their law enforcement objectives. ${ }^{123}$

Writing just after the decision in Mapp $v$. Ohio, Francis A. Allen declared that up to that time, "no effective quantitative measure of the rule's deterrent efficacy has been devised or applied."124 That conclusion is not yet outdated. The foregoing findings represent the largest fund of information yet assembled on the effect of the exclusionary rule, but they obviously fall short of an empirical substantiation or refutation of the deterrent effect of the exclusionary rule. They also fall short of demonstrating a research method by which that important question could be determined. That is the subject of the next section.

\section{Designing an Empirical Test of the Deterrent EFFECT OF THE EXCLUSIONARY RULE}

As used here, the concept of deterrence embodies all of the forces that unite to discourage a person from violating a rule. This section reviews various aspects of deterrence suggested in the literature on the deterrent effect of punishments, applies them to the exclusionary rule, and discusses possible techniques and areas for further research.

\section{A. Aspects of Deterrence}

Although the subject has only recently caught the interest of a sub. stantial number of scholars, a useful body of writing on the deterrent effect of punishments is already beginning to emerge. ${ }^{125}$ The literature identifies two different types of deterrence.

Special deterrence (or "special prevention") is the effect of a sanction on an individual who has already experienced it. It measures the likelihood of his repeating particular behavior once he has been singled out to taste its consequences. The exclusionary rule is not aimed at special deterrence since it does not impose any direct punish-

123 See text following notes 91 \& 95 supra.

124 Allen, supra note 3, at 34.

125 Andenaes, General Prevention-Illusion or Reality?, 43 J. CRIM. L.C. \& P.S. 176 (1952); Andenaes, The General Preventive Effects of Punishment, 114 U. PA. L. REv. 949 (1966); Andenaes, Does Punishment Deter Crime?, Il CRIM. L.Q. 76 (1968); Crampton, Driver Behavior and Legal Sanctions: A Study of Deterrence, 67 MrCH. L. REv. 421 (1969); Morris \& Zimring, Deterrence and Corrections, 381 ANNals 137 (1969); H. PACKer, The Limits of the Criminal Sanction 39.45 (1968); Schwartz \& Orleans, On Legal Sanctions, 34 U. CHr. L. REv. 274 (1967); Zimring \& Hawkins, Deterrence and Marginal Groups, 5 J. Res. Crime \& Deirne. 100 (1968); Zimring, Perspectives on Deterrence (Center for Studies of Crime and Delinquency, National Institute of Mental Health, Monograph Series, 1970). 
ment on a law enforcement official who has broken the rule. An officer may of course experience disappointment at seeing evidence suppressed and an offender go free, and that experience may affect his future behavior. If the officer also had to suffer departmental discipline or forfeit promotion, prestige, or other advantages because of the application of the exclusionary rule to his cases, then this could give the exclusionary rule an important special deterrent effect. But diligent inquiry has failed to reveal a single law enforcement agency where individual sanctions are tied to an application of the exclusionary rule. The rule is apparently expected to achieve its purpose without them. The exclusionary rule is aimed at affecting the wider audience of all law enforcement officials and society at large. It is meant to discourage violations by individuals who have never experienced any sanction for them. The exclusionary rule is therefore meant to achieve its purpose through what is called general deterrence (or "general prevention").

General deterrence includes two kinds of effects, one immediate and the other long range. The immediate effect is direct deterrence, which is the compliance induced by the threat of the sanction. It is of course dependent upon effectively communicating the rule and the nature of the sanction to the individuals supposed to be affected by it. If they do not "get the message" there will be no direct deterrence. In the context of the exclusionary rule, direct deterrence is the extent to which the law enforcement officer observes the search and seizure rules because of his realization that the evidence will be inadmissible in court if he does not. In addition to communication, direct deterrence is also dependent upon how gravely law enforcement officers view the consequences of excluding evidence, and upon how they compare those consequences with the competing alternatives. In other words, the direct deterrent effect of the exclusionary rule will depend upon the individuals' perceptions of the relative costs of conformity or nonconformity with the rule. ${ }^{126}$ Those perceptions will of course vary from person to person and from one group to another. There will also be differences in the extent to which individuals actually make conscious or unconscious weighings of the consequences before acting. An article of faith in respect to the deterrent effect of the criminal law is its greater probable effect upon deliberate crimes like burglary or embezzlement than upon impulsive crimes like assault. Because the exclusionary rule operates upon conduct that is generally quite de-

126 This analysis is traceable to Jeremy Bentham. H. PACKER, supra note 125, at 40-41. Some observers, persuaded that potential criminals do not weigh the pros and cons before acting, have rejected the whole idea of direct deterrence in respect to the criminal law. Others affirm the value of the analysis, but urge that it be applied selectively. Id. at 41 ; Zimring, supra note 125 , at pt. I. The succeeding text tries to do this. 
liberate and frequently even the result of formal or informal law enforcement policies, it is likely to involve a calculation of alternatives at some point. The extent of such weighing will of course vary from group to group within the law enforcement community. For example, it may be minimal in respect to patrolmen and considerable in respect to detectives or other highly trained and disciplined groups.

In addition to direct deterrent effect, a sanction has a variety of indirect and long range effects that operate to discourage violations of the rule. The writings of Johannes Andenaes, Herbert Packer and Franklin Zimring identify three indirect ways in which the threat of punishment may play a role in deterring violations of the criminal law. ${ }^{127}$ All have some relevance to the probable deterrent effect of the exclusionary rule.

The first and probably most important is the "moral or educative influence" of the law. What Packer calls the "heavy symbolic signifcance" of the criminal sanction is an important ingredient in teaching what society accepts and what it will not accept as appropriate personal behavior. "The act is branded as reprehensible by authorized organs of society," Andenaes states, "and this official branding of the conduct may influence attitudes quite apart from the fear of sanctions." 128 The existence and imposition of a sanction reinforces the rule and underlines the importance of observing it. The principle is directly applicable to the exclusionary rule. The salient defect in the rule of Wolf $v$. Colorado was the difficulty of persuading anyone that the guarantees of the fourth amendment were seriously intended and important when there was no sanction whatever for their violation. As a visible expression of social disapproval for the violation of these guarantees, the exclusionary rule makes the guarantees of the fourth amendment credible. Its example teaches the importance attached to observing them. ${ }^{129}$

As a second indirect effect, a threat of punishment for violation of the rules helps to develop patterns or habits of conforming behavior that continue to influence an individual's conduct long after he has ceased to weigh the pros and cons of observance. This is also a

127 Andenaes, Does Punishment Deter Crime?, 11 CRTM. L.Q. 76, 80-8I (1968); H. PACkeR, supra note 125, at 42-45; Zimring, supra note 125 , at pt. I.

128 Andenaes, supra note 127 , at 81 .

120 This point combines two effects described by Zimring, the effect of the rule in teaching what society views as right and wrong, and the effect of the threat or imposition of punishment in convincing the doubtful that society means what it says. As to the latter Zimring observes: "If the solemn commands of a legal system were not reinforced with the threat of punishment, many individuals would see no basis for concluding that the legal system really meant what it said." Zimring, supra note 125 , at pt. I, § 3 . 
potential result of the exclusionary rule, at least as to those aspects of law enforcement conduct that become highly routine.

A third indirect effect of a sanction is that it assists a potential offender by giving him an additional reason to resist temptation and avoid the proscribed conduct. ${ }^{130}$ In the immediate context, this reason suggests that the exclusionary rule may be valuable in reinforcing the position of law enforcement officials who are disposed to observe the search and seizure rules but need something tangible to give fellow officers as their reason for doing so.

\section{B. Designing an Empirical Test}

It is no easy task to design an empirical test of the deterrent effect of the exclusionary rule. The measurement of direct deterrent effect is difficult enough, without having the problem further complicated by the probability of important indirect effects.

1. Research Methods. Most of the possible research techniques were illustrated in the preceding section-the before-after comparison, the multiple-area comparison, and the field observation. ${ }^{131}$ One addition is the field experiment, which tests the effect of a rule in a single area during a single period of time by making the presence or absence of the rule the only variable between two otherwise similar experimental groups or situations. ${ }^{132}$ As applied to the exclusionary rule, serious constitutional and practical difficulties prohibit the field experiment and the multiple-area comparison, since the Mapp decision eliminates the basis for comparison by requiring the exclusionary rule to be used in every jurisdiction and group of cases in this country..$^{133}$

The most promising method for an overall test of the deterrent effect of the exclusionary rule is the before-after test. About 24 states were abruptly compelled to adopt the exclusionary rule in 1961 when Mapp v. Ohio made it a constitutional requirement. ${ }^{134} \mathrm{~A}$ before-after

130 Zimring, supra note 125 , at pt. I, § 4 .

131 See text preceding note 65 supra. The various methods are discussed in Andenaes, The General Preventive Effects of Punishment, 114 U. PA. L. REv, 949, 973-8 (1966); Crampton, supra note 125, at 449-52; Morris \& Zimring, supra note 125, at 144-5. Another method, basic research, attempts to contribute to the knowledge of deterrence by enlarging what is known about behavior in general or the ingredients or determinants of behavior in the special context of deterrence. This paper has nothing to contribute in the way of basic research, which is predominantly the domain of disciplines other than law.

132 See Schwartz \& Orleans, supra note 125, at 284-6. For an excellent summary of "the tools of causal analysis," see H. Zeisel, SAY IT with Figures ch. 7 (5th ed. rev. 1968).

133 Apart from the Mapp ruling, any experimental situation that applied one legal rule to one group of defendants and another rule to another group would raise serious questions under the requirements of equal protection. Morris, Impediments to Penal Reform, 33 U. CHI. L. REv. 627, 645-55 (1966); Crampton, supra note 125, at 451-2.

134 The following states did not apply the exclusionary rule in June, 1960, one year 
test can focus on changes that occurred in any of these areas when $M a p p$ was adopted. At this point, almost ten years after $M a p p$, there are obvious difficulties. Methods dependent upon subjective evidence, such as questionnaire or interview explanations or opinions of law enforcement personnel, probably will not yield conclusions of acceptable certainty. The passage of time gives added force to the usual objections that such subjective responses are apt to be clouded in ambiguity or distorted by faulty recollection or bias. As for objective data, much of this will have been destroyed since 1961. But some will remain.

The major difficulty with a before-after test is in locating some objective manifestation of behavior or change in behavior of law enforcement personnel that can be said to be primarily attributable to the exclusionary rule. The ideal criterion would be the number or rate of illegal searches; that is, searches not authorized by a valid search or arrest warrant or incident to an arrest based on probable cause. But how does one ascertain which searches were legal and which were illegal, especially when the events took place seven to nine years ago? Even if there were a written record of the search-which is unlikelythe record would rarely show whether the arrest was in conformity with all the rules. And it is in the nature of things that there will be no written record of many illegal arrests and searches. The only available information about these events will be the subjective recollection of participants, which is not a reliable source for the reasons suggested earlier.

It is therefore necessary to seek objective criteria that are, at best, indirect evidence on the question. A comparison of the number of motions to suppress before and after the adoption of the exclusionary rule would provide no illumination. The number of motions would be negligible before and relatively numerous after. That difference would merely attest to the obvious fact that lawyers will not make a motion to suppress when the evidence cannot be excluded and will when it can. ${ }^{135}$ Changes in the number or proportion of arrests with

before Mapp: Arizona, Arkansas, Colorado, Connecticut, Georgia, Iowa, Kansas, Louisiana, Maine, Massachusetts, Minnesota, Nebraska, Nevada, New Hampshire, New Jersey, New Mexico, New York, North Dakota, Ohio, Pennsylvania, South Carolina, Utah, Vermont and Virginia. In addition, four other states had only a partial exclusionary rule: Alabama, Maryland, Michigan and South Dakota. Elkins v. United States, 364 U.S. 206, 224-32 (1960) (appendix). Other states with relatively recent changes are Delaware, which adopted the exclusionary rule in 1950, North Carolina in 1951, California in 1955, and Rhode Island in 1956. Allen, supra note 3, at 27-28.

135 Significant trends in the proportion of motions to suppress that are granted over a substantial period of years might be indicative of changes in police behavior. Thus, if the rate of suppression declined, this might indicate that the amount of illegal police 
a warrant and without a warrant might provide a valuable contrast before and after the exclusionary rule was adopted. However, this information is not likely to be available. Police and court records are not geared to answering questions about the manner of arrest or the number of warrants issued in a particular period of time. Moreover, the passage of time since Mapp $v$. Ohio often will have resulted in the destruction of whatever records were kept. The author contacted several large police departments and none could furnish this warrant information.

In sum, it appears that so far as existing statistics are concerned, there is no better indirect statistical measure of the effect of the exclusionary rule on conformity to search and seizure rules than arrest and conviction rates in selected crimes and data on seizure of selected types of property. Both of these were illustrated in the preceding section.

There are many difficulties with such indirect tests of the deterrent effect of the exclusionary rule. Two are apparent at the surface. The first is that the exclusionary rule is only one of a variety of possible causes for changes or lack of changes observed in the indicia being used. The amount of seizures of property, for example, may be attributable to changes in enforcement efforts (such as the changing number of gambling raids noted in Figure 4) that have no relationship to the exclusionary rule. As a first step, the researcher must eliminate alternative causes and satisfy himself that the effect observed in the index was actually caused by the exclusionary rule.

The second difficulty, which is inherent in the use of indirect methods to test the deterrent effect of the rule, is that the exclusionary rule may affect the index without affecting the illegal behavior. Thus, the Columbia University study measured changes in the reasons police gave before and after the $M a p p$ decision for making narcotics arrests. Even after it is assumed that the Mapp case produced the changes, there is still a question as to whether the change represents a change in police conduct in arrests or merely a change in police reports about arrests. ${ }^{136}$ Similarly, adoption of the exclusionary rule may make no

behavior was declining. But the evidence is ambiguous. A decline might also result from increases in the number of frivolous motions, changes in the substantive law of search and seizure, or changes in patterns of police testimony. On the latter, see text following note 85 supra.

136 Relying on their assumption that the police were unlikely to have changed their behavior in the way indicated in their reports, the Columbia students concluded that after the Mapp case some police were giving false reports of the reasons for their arrests. Text at note 88 supra. That conclusion cannot be validated until the underlying assumption is proven. If the conclusion is correct, then the proven fact of police fabrication is important in weighing the desirability of the exclusionary rule, as discussed more fully 
change whatever in the degree of official observance of search and seizure rules, but may still cause police officers to change their method of disposing of property that has been illegally seized (such as by substituting private destruction or confiscation for official inventory procedures). If so, then changes in the index of contraband seized could give a false impression of changes in actual police adherence to the rules.

2. The Complexity of the Question. There is a more pervasive difficulty with all of the foregoing methods for measuring the deterrent effect of the exclusionary rule; they all tend to oversimplify an enormously complex inquiry. All suggest a simple answer to a simple question-whether or not the exclusionary rule deters police from illegal behavior. But the subject is not as simple as determining whether the suspect's fingerprint is on the gun, yes or no. Any attempt to determine whether or the extent to which the exclusionary rule affects the behavior of law enforcement personnel confronts an exceedingly complicated inquiry into human motivation within a complex social model, the criminal justice system.

The breadth and complexity of the motivation problem is implicit in Packer's suggestion that an inquiry into the operation of general deterrence in the criminal law should be broadened to include the effect of punishment "on the totality of conscious and unconscious motivations that govern the behavior of men in society."137 Andenaes has suggested that any realistic discussion of general deterrence must give individual consideration to each of the various reasons individuals have for violating various types of rules. ${ }^{138}$ Zimring discusses six variables that account for great differences in the general deterrent effects of a sanction: (1) differences among men, (2) varieties of threatened behavior, (3) differences in the way the threat is communicated, (4) individual perceptions of the applicability and credibility of the threat, (5) variations in threatened consequences, and (6) the moral quality of the threatened behavior. ${ }^{139}$

We are just beginning to sense the complexities of the criminal justice system and its enormous variations from city to city and state to state. Variations in the organization and style of police departments, such as those discussed in James Q. Wilson's Varieties of Police Be-

hereafter. But the fact of fabrication is not direct evidence on the overall deterrent effect or lack of deterrent effect of the exclusionary rule. It is evidence on the issue of deterrence only if one infers that the reports were falsified in order to avoid the effect of the exclusionary rule. For another possible explanation of the data see note 90 supra.

$137 \mathrm{H}$. PACKER, supra note 125 , at 42.

138 Andenaes, supra note 127, at 80.

130 Zimring, supra note 125, at pt. III, § I. See also Zimring \& Hawkins, supra note 125. 
havior, ${ }^{140}$ are bound to have an important effect on whether, when, and how much a legal rule will affect police behavior. And it must be remembered that "the police" is not a monolithic entity. There are officers in positions of command, staff, special assignment (like narcotics detail) and patrol, to name only a few. A policeman's perceptions of the search and seizure rules and of the exclusionary rule as an enforcement device are bound to be affected by his assignment and by the way he interacts with other police and with personnel in other parts of the criminal justice system. The role of the prosecutor is subject to great variation, as pointed out in the contrast between Chicago and the District of Columbia. And the manner in which courts perform their function is another variable of immense diversity.

In this incredibly diverse milieu of different police departments and criminal justice systems and different individual motivations and sensitivity to sanctions, the researcher must consider not one but a variety of possible effects, some long term and some short term, some subtle and some obvious. In addition to the direct deterrent effect of the exclusionary rule, he must try to measure its indirect impact, such as its moral or educative effect.

In view of the complexity of the inquiry, it presently appears to be impossible to design any single test or group of tests that would give a reliable measure of the overall deterrent effect of the exclusionary rule on law enforcement behavior. But it is possible to nibble around the edges of the problem by small inquiries that illuminate areas of special importance. The most promising of these are the inquiries discussed below.

3. Promising Areas for Research. There are four particularly promising areas for study in this field, any one of which might yield valuable information as to the efficacy of the exclusionary rule and as to possible alternatives or supplements to the rule.

(a) Analyzing the violations. The single most important unanswered question concerning the effect of the exclusionary rule is why police officers break the search and seizure rules. We know that there is widespread illegal law enforcement behavior, and we know the areas of law enforcement behavior in which it is concentrated. We need to focus on these areas to determine what causes line officers to observe the law of arrest and search and seizure in various situations, and what causes them to break it. This would require identifying the most common types of police violations of search and seizure rules in the enforcement of various types of crime. It would require determining what illegal searches and seizures were approved by law

140 J. Wilson, Varieties of Police Behavior (1968). 
enforcement norms, and why they were approved. It would result in an analysis of the relative costs of conformity and nonconformity with the rules of search and seizure. (For example, why do officers arrest a person or search an area without obtaining a warrant to do so?) $)^{141}$ This inquiry could not be pursued by examining existing statistics. It would require quantitative analysis of new information derived from observation and conversation with officers and victims. It would follow the technique of "reason analysis" described by Hans Zeisel. ${ }^{142}$

(b) The Canadian experience. Another important and practical area for research would be the operation of supplements or alternatives to the exclusionary rule. One promising approach would be a study of how the Canadians manage to discourage illegal law enforcement behavior. The brief observations about Toronto in the preceding section suggest a number of inquiries to pursue. ${ }^{143}$

(c) The tort remedy. As another possibility, scholars have frequently suggested a tort cause of action against the offending officer or his employer as a supplement or alternative to the exclusionary rule. ${ }^{144}$ There is need for a study of the extent to which the tort remedy is presently used for this purpose, and especially of the extent to which employing agencies try to reduce illegal behavior when they are subjected to damage liability for it. There is almost no published factual information. ${ }^{145}$ The study should also seek to determine what

141 Some police officers have complained to the author that the arrest and search and seizure rules are so inhibiting that they cannot make a valid arrest or search and get a conviction even where they know that a particular person possesses stolen goods and where those goods are located. They claim that their reliable policeman's intuition cannot be translated into the necessary probable cause for a warrant. Consequently, the choice is often between an elaborate stakeout involving hundreds of hours of police time that is badly needed elsewhere or a breaking of the rules that recovers the stolen property but forgoes the conviction. In other instances police claim that the time and trouble of obtaining a warrant is prohibitive in view of the practical exigencies of law enforcement. These and other asserted costs of conformity should be evaluated to determine whether the true source of difficulty is the substantive rule or the way in which it is administered by police or courts.

142 H. ZEIseL, supra note 132, at chs. 10-11.

143 See text accompanying note 100 supra.

144 Authorities cited notes 36 \& 37 supra.

145 William M. Briggs, J.D. '69, then a University of Chicago Law School student, examined the docket books of the federal district court in Chicago for the years 1960 to 1967 to obtain a sample of 35 civil rights damage actions against police officers in which the City of Chicago or the police superintendent or department was originally joined as a co-defendant. The actions arose out of circumstances in which most of the plaintiffs had criminal charges placed against them. The plaintiffs prevailed in 18 of these cases ( 3 by jury trial and 15 by settlement or bench trial), and obtained judgments totalling $\$ 126,000$. The City of Chicago paid the judgments under state law, note 37 supra, but not one of the 18 officers who had been found in the wrong was disciplined by the Police Department, not even by reprimand. Briggs, 42 U.S.C.A. Section 1983: An 
changes of substantive law or procedure would give the aggrieved individual a practical damage remedy against the officer or his employer. It may be advisable to modify the terms of the tort cause of action or the measure of damages or to make provision for counsel for the plaintiff. The Constitution undoubtedly leaves Congress and the state legislatures wide latitude in such matters. The present tort remedy is ill suited for controlling the police since the measure of damages is not related to the enormity of the wrong committed by the defendant (police officer). Instead, the damages are determined by the injury suffered by the plaintiff, and that injury often cannot be measured in economic terms. ${ }^{140}$ This defect could of course be remedied by changes in the cause of action and the measure of damages. ${ }^{147}$ It is also suggested that juries will not give adequate verdicts against police officers, especially in favor of a plaintiff who was an accused or convicted criminal. Then the law might be changed to abolish juries in such cases. An individual police officer may have a constitutional right to a jury trial, at least in a common law action for damages, but a governmental body probably does not. Judges or administrative bodies will probably be willing to award significant damages for invasions of constitutional rights, even to those guilty of crimes. By means of the exclusionary rule the state judiciary has grown accustomed to compensating a guilty person who was aggrieved by an illegal search by awarding him his freedom. There is no reason to suppose that they would be less willing to give money damages as a form of compensation, especially when the remedy would extend to all who were aggrieved, the innocent as well as the guilty. If the Ganadian research verifies that the Canadians have a practical tort remedy against law enforcement officers, that study could also suggest other changes for this country.

Recent cases in the federal courts may portend the development of one or more effective federal damage remedies against illegal law enforcement conduct. On the subject of damages, a Seventh Circuit decision held that a plaintiff in a civil rights action could recover for attorney's fees incurred and for confinement suffered as a result of

Effective Deterrent to Police Brutality? (unpublished research paper on file in University of Chicago Law School Library).

146 Weiler, supra note 100, at 443-7; Foote, supra note 36, at 496-500. Foote contrasts the action for trespass, which he calls "completely impotent," with the "steady trickle of false imprisonment cases." The difference is in the higher damage ceiling for false imprisonment because "the jury is given wide scope in attaching a dollar value to immeasurables such as the sense of humiliation, distress, disgrace or outrage, or the usually fictional damages to reputation." Foote, supra note 36, at 497-8.

147 For a list of suggested changes to make the tort action an effective remedy against police misconduct, see Foote, supra note 36, at 504-16. 
invasion of his constitutional rights. ${ }^{148}$ A Fourth Gircuit case held that a youth whom a police officer had shot in a reckless use of force during an arrest attempt could recover damages under the Civil Rights Act, and could also recover damages-including pain and suffering-for assault and battery under a pendent claim based on state law. ${ }^{149}$ As for the cause of action, the Second Circuit has recently held in a case of first impression that an unconstitutional search and seizure does not, in the absence of legislation, give rise to a federal cause of action for damages, but a concurring judge observed that the plaintiff should have a federal cause of action, and served notice that his concurrence in denying relief was only temporary. ${ }^{150}$

(d) Some negative research. Though it may not be feasible to attempt to answer the massive overall question of whether and to what extent the exclusionary rule does deter illegal searches and seizures by law enforcement personnel, it is possible to approach the problem step by step from the negative side by seeking, first, to determine what the exclusionary rule does not accomplish and, second, to identify some negative effects that its use may entail. The questions posed by this approach are numerous but relatively simple.

The remaining two parts pursue this twofold inquiry. Part V examines some limitations upon the effectiveness of the exclusionary rule in various circumstances. These limitations reveal some areas where the exclusionary rule may be ineffective and some weaknesses that probably reduce its impact in areas where it may have effect. By exploring what the exclusionary rule does not accomplish, this part will define the limits of the rule. It will also suggest ways in which the effectiveness of the rule could be enhanced. Part VI will examine some asserted negative effects or costs entailed in the application of the exclusionary rule. Where the assertions examined in these two parts seem to be based upon matters of fact or where they are subject to challenge or substantiation by factual inquiry, the discussion will refer to some evidence on the critical facts or suggest methods of empirical research by which such evidence could be obtained.

148 Kerr v. City of Chicago, 424 F.2d 1134 (7th Cir. 1970).

149 Jenkins v. Averett, 424 F.2d 1228 (4th Cir. 1970). Cases on the liability of police officers for negligently causing personal injury or death are collected in 60 A.L.R.2d 873 (1958). The court's suggestion of pain and suffering damages in this case is significant since studies have shown that in awarding damages under this heading " $[t]$ he jury seems to be responding not to pain as such but to the dignitary aspects of the injury . . . B" Blum \&: Kalven, Public Law Perspectives on a Private Law Problem-Auto Compensation Plans, 31 U. CHI. L. Rev. 641, 673 (1964), cited in Weiler, supra note 100, at $447 \mathrm{n.57}$.

150 Bivens v. Six Unknown Named Agents of the Fed. Bureau of Narcotics, 409 F.2d 718, 726 (2d Cir. 1969) (Waterman, J., concurring). 


\section{Limitations UPON THE DETERRENT EFFEctiveness OF THE EXGLUSIONARY RULE}

This section examines some probable limitations upon the effectiveness of the exclusionary rule as a means to deter illegal searches and seizures. Some of these limitations relate only to the effect of the rule on particular types of police behavior, while others have broader application, challenging the whole deterrent theory of the rule. In focusing on possible weaknesses in the exclusionary rule, this section may provide ammunition for those who would seek to abolish or restrict its application. But the information contained here should also be useful for those who are interested in understanding the rule's weaknesses in order to strengthen or supplement it with additional mechanisms for controlling official behavior. ${ }^{151}$

\section{A. A Sanction Limited to Evidence Offered at Trial}

The salient weakness of the exclusionary rule as a device to deter improper police behavior is that its penal effect is felt only when a case comes to court and there is an attempt to introduce illegally obtained evidence to secure a conviction. Consequently, the exclusionary rule is not likely to be an effective deterrent against official misconduct if that misconduct is not directed toward acquiring evidence or if it is not likely to result in a prosecution. These two limitations cover such a high proportion of law enforcement activity that they leave relatively little latitude for the operation of the exclusionary rule. "A great majority of the situations in which policemen intervene are not, or are not interpreted by the police to be, criminal situations in the sense that they call for arrest with its possible consequences of prosecution, trial and punishment."152 And even among the small category of arrests, less than ten per cent of the defendants are charged with any of the seven serious offenses that make up the F.B.I. crime index ${ }^{153}$ and lead to the most seriously conducted prosecutions. A large proportion of arrested persons are released without any charges being brought..$^{154}$ The question suggested by the foregoing facts is how can the exclusionary rule have a significant effect on reforming or controlling police behavior when its only impact concerns a tiny fraction of that behavior?

151 See generally LaFave, Improving Police Performance Through the Exclusionary Rule, 30 MO. L. REv. 391, 566 (1965).

152 Report of the President's Commission on LAW Enforcement and administration of Justice, The Challenge of Crime in a Free Society 91 (1967). Examples include quieting noisy parties, helping drunks, returning runaways and settling family squabbles. 153 J. Wilson, Varieties of Police Behavior 6 (1968).

164 TASK Force REPORT: The POLICE at 186-7. 
The exclusionary rule is unlikely to affect those forms of official misbehavior which the offending officer considers unlikely to result in the acquisition of evidence that could be presented in court. Thus, it is unlikely to deter physical abuse of persons in custody, unnecessary destruction of property, illegal detentions (unless leading to acquisition of evidence), taking or soliciting bribes, and extorting money on threat of arrest or other sanction. ${ }^{155}$

On the subject of conduct likely to result in prosecution, Chief Justice Warren made the point succinctly in Terry $v$. Ohio:

Regardless of how effective the rule may be where obtaining convictions is an important objective of the police, it is powerless to deter invasions of constitutionally guaranteed rights where the police either have no interest in prosecuting or are willing to forego successful prosecution in the interest of serving some other goal. ${ }^{156}$

This is a familiar point. ${ }^{157}$ Informed observers have suggested a variety of goals or motivations other than obtaining convictions that may prompt police arrest and search and seizure. ${ }^{158}$ These include arrest or confiscation as a punitive sanction (common in gambling and liquor law violations), ${ }^{159}$ arrest for the purpose of controlling prosti-

155 Barrett, supra note 37, at 584-5, 592-3; Barrett, Personal Rights, Property Rights and the Fourth Amendment, 1960 SUP. Cr. REv. 46, 54-55. Evidence unexpectedly obtained as the fruits of such illegal conduct can of course be suppressed, Wong Sun $v$. United States, 371 U.S. 471 (1963), but that prospect is unlikely to exert a deterring influence on law enforcement officials if they do not expect to obtain evidence when they engage in the conduct in question.

150392 U.S. I, 14 (1968).

157 W. LAFAve, supra note 34, at 488; TASK Force REPORT: THE Police at 18-19, 31, 200; J. SkolNick, supra note 91, at 225; Allen, supra note 3, at 37-39; Barrett, supra note 155, at 54-55; LaFave \& Remington, supra note 29, at 1008-11; Schaefer, supra note 24, at 14; Comment, Judicial Control of Illegal Search and Seizure, 58 YALE L.J. 144, 148 (1948).

A young Vista volunteer working with juveniles in the Uptown area of Chicago gave vivid expression to the same idea in testimony before the Bill of Rights Committee of the Sixth Illinois Constitutional Convention in February, 1970. After accusing police of maintaining "a sort of reign of terror against the most innocent and worthwhile activities of any group that's young, poor, defenseless and wears their hair long," he suggested a rule restricting "stop and frisk" practices. "But I really wonder what good a rule like that would do," he concluded, "when there aren't any real penalties you could lay on the cops for violating it. Suppressing the evidence of a bad bust may discourage the rotten investigative tactics of officers who are really trying to solve crimes, but it doesn't have the slightest effect in cramping the style of uniformed gunmen who are just out to make life miserable for a certain class of society."

158 W. LAFAvE, supra note 34, at chs. 21-24; LaFave, supra note 151, at 448-55; J. SkolNick, supra note 91, at 220; F. MiLLER, supra note 78, at 246-50.

159 For example, 3,719 defendants were arrested for "investigation" in Baltimore in 1964. After being held for up to three days, $98 \%$ were released without charge. TAss 
tutes and transvestites, arrest of an intoxicated person for his own safety, search for the purpose of recovering stolen property, arrest and search and seizure for the purpose of "keeping the lid on" in a high crime area or of satisfying public outcry for visible enforcement, search for the purpose of removing weapons or contraband such as narcotics from circulation, and search for weapons that might be used against the searching officer. ${ }^{160}$ A large proportion of police behavior is traceable to these reasons for arrest and search and seizure and thus is not likely to be responsive to any deterrent effect of the exclusionary rule.

The variety of reasons for an improper search and seizure is in marked contrast to the limited number of reasons why police would engage in the kind of illegal conduct that causes the exclusion of a coerced confession or an improper lineup identification. In exceptional situations a person may be interrogated just to obtain the recovery of stolen property, to locate a kidnapped person or to clear a crime, all without intention of prosecuting. But the predominant incentive for interrogation is to obtain evidence for use in court. Consequently, police conduct in this area is likely to be responsive to judicial rules governing the admissibility of that evidence. "There can be no doubt," the President's Crime Commission reported, that the Supreme Court's rulings about interrogation procedures "had much to do with the fact that today the third degree is almost nonexistent." 101 James Q. Wilson has observed that the problem of interrogation was relatively easy to bring under judicial control by appellate decisions "precisely because it was part of the crime-solving function of the police ...."162 The same success may be expected for the new

FORCE REPORT: THE COURTS at 121. See also the discussion of extra-judicial punishments in text following note 250 infra.

160 "Preventive patrol often involves aggressive action on the part of the police in stopping persons using the streets in high-crime areas and in making searches of both persons and vehicles .... to find and confiscate dangerous weapons and to create an atmosphere of police omnipresence which will dissuade persons from attempting to commit crimes because of the likelihood of their being detected and apprehended." TASR FOREE REPORT: THE POLICE at 23. Thus, a 1966 Crime Commission study reported that 12 per cent of the 224 persons frisked in high-crime neighborhoods in Boston, Chicago and Washington, D.C. were carrying guns and that another 8 per cent were carrying knives. The legality of "a very high proportion" of these searches was considered highly questionable. Some persons found carrying weapons were released in the field. Black \& Reiss, Patterns of Behavior in Police and Citizen Transactions, 2 Studies in CRMm AND LAW ENForcement in Major Metropolitan AREAS § 1, at 87, 90-91 (undated); The Challenge of Crime, supra note 152, at 94-95.

161 The Chatlenge of Crime, supra note 152, at 93; Task Force Report: The Police at 181.

$162 \mathrm{~J}$. Wirson, supra note 140 , at 48 . Others are less sanguine about the deterrent success of the interrogation rules, at least as regards the Miranda warnings. 
rulings on lineup identifications. But the exclusionary rule has not been successful and is not likely to be successful in achieving a comparable elimination of illegal arrests and searches and seizures because the object of much of the challenged conduct is the maintenance of order rather than the prosecution of crime.

A related doubt about the effectiveness of the exclusionary rule arises from the fact that a large majority of defendants plead guilty. ${ }^{163}$ Robert Emmet Burns observes:

It is an eminently fair question to ask whether local police, well aware of calendar turnover and voluntary guilty pleas in urban centers, are in fact deterred or encouraged to be fairer than otherwise. If capital punishment does not deter an offender because it will not happen, why should court exclusion of evidence or appellate reversal of trial decisions deter police when ninety per cent of the time there will be no triallite4

Albert W. Alschuler points out that illegally obtained evidence contributes to a successful prosecution where the defendant pleads guilty before litigating his motion to suppress, but the prosecution pays a price in the form of a reduced sentence. He poses the critical question "whether a reduction in sentence, even in a large number of cases, can achieve a deterrent effect similar to that produced by the elimination of conviction in a few."105

Empirical Research. The foregoing discussion has suggested the hypothesis that there will be little or no deterrent effect upon police conduct not intended to obtain evidence for use in a prosecution, and it has given a variety of examples of such conduct. Any of these examples could be examined by a before-after test if objective evidence is still available, or by contemporary observation of law enforcement officers in action. Even with conduct intended to result in a prosecution, it should be possible to identify types of police behavior or types of crime where the exclusionary rule is comparatively inef-

103 The proportion of defendants who plead guilty varies from $35 \%$ to $95 \%$, depending upon the crime charged and the practices of the particular jurisdiction. Nationally, narcotics and weapons charges involve about $70 \%$ guilty pleas, which is about the national average for all crimes. Figures on various crimes appear in Oaks, The Criminal Justice Act in the Federal District Courts, Senate Comm. on the Judiciary, Subcomm. on Constitutional Rights, 90th Cong., 2d Sess. 288 (Comm. Print 1969) (federal court); H. Kalven \& F. Zeisel, The American Jury 20 (1966) (national averages); D. OAks \& W. LeHMAN, supra note 73, at 59, 66 (Illinois data and national averages).

164 Burns, supra note 30 , at 95-96.

165 Alschuler, The Prosecutor's Role in Plea Bargaining, 36 U. GFI. L. REv. 50, 82 (1968). 
fective as a deterrent. There is a working hypothesis in the suggestion that the exclusionary rule will be less effective in those crimes where a comparatively high percentage of defendants plead guilty. There is another hypothesis in the suggestion that police are less likely to be interested in convictions and more likely to be making illegal intrusions on privacy in the so-called "victimless crimes" such as gambling, liquor, narcotics, prostitution and sexual immorality, where the gravity of the crime (as measured by penalties actually imposed) is relatively insignificant and where there is public clamor for visible enforcement. Just about half of all arrests are for crimes of this character. ${ }^{166}$ It is in this area, Allen concludes, that "[t]he threat of the exclusionary rule is likely to have little potency . . ."167 A high proportion of motions to suppress involve such crimes. ${ }^{168}$

\section{B. Unfavorable Conditions for Deterrence}

The exclusionary rule operates under conditions that are unfavorable for effective general deterrence, at least by means of direct deterrent effect. The pioneering work of Johannes Andenaes and the writings of subsequent scholars suggest that the general deterrent effect of legal sanctions will be affected by the following conditions.

(1) The effect will vary according to the individual's perceptions of the risk of detection, conviction and punishment. ${ }^{169}$

(2) The effect will vary according to the individual's perception of the severity of the penalty. ${ }^{170}$

(3) The effect of the legal sanction may be neutralized when the forbidden behavior is approved by the relevant community and when conviction entails no loss of prestige. ${ }^{171}$

(4) A legal sanction is most likely to be an effective deterrent when it is reinforced by a sense of moral obligation or an appeal to conscience. ${ }^{172}$

(5) A legal sanction is most likely to be an effective deterrent when

166 The Challenge of Criaie, supra note 152, at 20.

167 Allen, supra note 3, at 38-39. Consistent with that suggestion, Skolnick concluded that the exclusionary rule "seems to control police almost in direct relation to the gravity of the crime of the suspect." J. SkoLNick, supra note 91, at 225.

168 See text accompanying note 69 supra.

169 Andenaes, supra note 131, at 960-4; Crampton, supra note 125, at 426-7; Zimring, supra note 125, at pt. III, §\$ 1a. \& d.

170 Andenaes, supra note 131, at 964-70; Crampton, supra note 125, at 426-7; Zimring, supra note 125 , at pt. III, \& le.

171 Andenaes, supra note 131, at 950, 959-60; Crampton, supra note 125, at 427; Zimring, supra note 125, pt. III, \& $1 \mathrm{~d}$.

172 Schwartz \& Orleans, supra note 125, at 291-300. See also Andenaes, supra note 131, at 956-9; Zimring, supra note 125 , pt. III, \$§ 1b. \& f. 
the motivation to engage in the prohibited conduct is low and when there are readily available alternative courses of conduct to attain the desired goal..$^{173}$

(6) If the sanction is to be effective as a general deterrent it must be communicated to the target population. ${ }^{174}$

(7) A final condition, not separately listed by the scholars of deterrence but worthy of special emphasis in connection with the effect of the exclusionary rule, is the following: If a sanction is to be effective as a deterrent, the circumstances under which it will be applied must be stated with sufficient clarity that persons can pattern their conduct after it.

Examined under each of the foregoing categories, the exclusionary rule appears to be subject to serious limitations in its direct deterrent effect upon improper police behavior. Most of the limitations are identified in this statement by Judge (as he then was) Warren Burger:

Curiously, those in the legal world who contend most ardently that deterrence of crime by punishment is an outmoded concept are among the most vocal in claiming a deterrent effect for the suppression of evidence. If prisons do not deter forbidden conduct, how can we think that a policeman will be deterred by a judicial ruling on suppression of evidence which never affects him personally, and of which he learns, if at all, long after he has forgotten the details of the particular episode which occasioned suppression? This is an important issue which proponents of deterrence-by-suppression must meet; it cannot be swept under the rug. ${ }^{175}$

1. Risk of Detection, Conviction and Punishment. A prime defect of the exclusionary rule is that police who have been guilty of improper behavior are not affected in their person or their pocketbook by the application of the rule. The perceived risk of unwanted detection and adjudication of fault is slight. If the officer has any reason to conceal improper behavior, the courtroom issue typically becomes a contest of credibility that the trier of fact is likely to resolve in favor of the officer. Moreover, as Justice Jackson once noted: "Rejection of the evidence does nothing to punish the wrong-doing official . . . ."176 So far as police command control is concerned, it is a notorious fact that police are rarely, if ever, disciplined by their superiors merely because they have been guilty of illegal behavior that caused evidence

173 Crampton, supra note 125, at 425; Zimring, supra note 125, at pt. III, § $1 \mathrm{~b}$.

174 Andenaes, supra note 131, at 950, 970; Zimring, supra note 125, at pt. III, \& 1c.

175 Burger, supra note 56, at 11. See generally LaFave, supra note 151.

176 Irvine v. California, 347 U.S. 128, 136 (1954). 
to be suppressed. As discussed more fully hereafter, ${ }^{177}$ if an officer is disciplined or disadvantaged because of his conduct in arrest or search and seizure, it will be for acting unreasonably as measured by norms of conduct other than those laid down in judicial decisions.

2. Severity of Penalty. The immediate impact of the exclusionary rule falls not upon the police but upon the prosecutor who is attempting to obtain a conviction. The impact is misplaced. The Presidential Commission's Report on the Police observed that the prosecutor "is not generally conceived of in this country as having overall responsibility for the supervision of the police."178 The relationship is generally that of independent and coordinate authorities, not always cooperating and sometimes even in conflict in the common task. ${ }^{179}$ The relationship can be explained in terms of the different motivations of prosecutor and police. The prosecutor's dominant career motivation is to prosecute and convict the guilty. The police, on the other hand, have a variety of motives other than to facilitate prosecutions. ${ }^{180}$ Consequently, the exclusionary rule is well tailored to deter the prosecutor from illegal conduct. But the prosecutor is not the guilty party in an illegal arrest or search and seizure, and he rarely has any measure of control over the police who are responsible. ${ }^{181}$ To the extent that the exclusionary rule does have any cor-

177 See text following note 183 supra.

178 TASK FORCE REPORT: THE POLICE at 30. "[N]either the police nor the prosecutor assume that the prosecutor has the responsibility either to stimulate or to participate in the development of administrative policies to control the wide range of police practices." $I d$. at 31. Chief Justice Warren Burger has criticized what he calls the "bland assumption by judges, especially appellate judges, that law enforcement is a monolithic governmental unity ... " He stated that "this confusion in the judicial mind is responsible for much of the continued vitality of the deterrence theory." Burger, supra note 56, at 12-13.

179 The President's Commission on Crime in the District of Columbia noted that:

[L]iaison between the police and the United States Attorney's office has been inadequate. Few new assistants have more than a casual awareness of police procedures, and learn these only coincidentally as they examine individual cases. In turn, the police receive only occasional direction from the United States Attorney on matters of such prosecution importance as confessions and search and seizure .... Rapport is erratic; policemen attribute lost cases to excessive prosecutive fastidiousness, and prosecutors blame police carelessness.

Report of the President's Commission on Crime in the District of Columbia 330-1 (1966).

180 See text following note 157 supra.

$181 \mathrm{Katz}$, supra note 67, at 141; Paulsen, supra note 58, at 257; Waite, Judges and the Crime Burden, 54 MrcH. L. REv. 169, 194 (1955). In some jurisdictions the prosecutor does not even screen proposed prosecutions and determine what charges shall be filed. D. OAKs \& W. LehMan, supra note 73, at 28-30 (Chicago); Meglio, Comparative Study of the District Attorneys Office in Los Angeles and Brooklyn, 5 THE PROSEGUTOR 237, 239-40 (1969) (Brooklyn).

It may or may not be coincidence that the police organization that has the best reputation for observing the arrest and search and seizure rules is the Federal Bureau of Investigation, which is (at least nominally) under the command control of the nation's 
rectional impact, it is not on police who deliberately engage in illegal behavior, but "against the police department which is trying to do its job of crime control [particularly by obtaining convictions] but is overzealous in its methods." 182

3. Competing Norms of Behavior. The exclusionary rule is unlikely to have a controlling effect upon a wide range of police behavior that is violative of the rules of arrest and search and seizure because any direct deterrent effect of the rule is neutralized by the keenly felt needs of the situation and by the competing norms of police behavior. Skolnick found that "norms located within police organization are more powerful than court decisions in shaping police behavior . . . ."183 Even if a police officer's conduct was illegal and resulted in loss of a conviction, Skolnick observed that the officer was assured of the sympathy of his superiors so long as he acted "in conformity with administrative norms of police organization . . . ."184 A police officer will be disciplined only if he has failed to behave as a reasonable officer should. The Crime Commission's Task Force Report on the Police found frequent instances in which:

[A]n officer's behavior is clearly illegal or improper, but is consistent with the routine practice of the particular agency and is generally condoned by its administration .... It is, for example, common for police officers to search the interior of a vehicle without legal grounds in high crime-rate areas. It is similarly common for police to search gamblers or arrest known prostitutes without adequate grounds. Since such actions are generally encouraged by superior officers, it is inconceivable that the officer would be administratively criticized or disciplined upon the filing of a complaint. ${ }^{185}$

High-ranking police officials in two different cities advised the author that their officers frequently enter and search a whole dwelling or make other illegal searches in order to recover stolen property. Officers are never disciplined for such action because, as one said, "society has a paramount interest in recovering stolen property." But thoughtful police officers feel the conflict, perhaps because of the accumulative

chief prosecutor. Compare the Canadian situation discussed in text following note 118 supra.

182 Barrett, supra note 37, at 586. See also Kitch, supra note 24, at 157.

183 J. SkolNick, supra note 91 , at 219. See also text accompanying note 91 supra.

184 Id. at 224. Thus, Superintendent $O$. W. Wilson of Chicago wrote in a department memorandum: "I will always support the police officer who, in the performance of his assigned tasks, exercises what he believes to be his authority in a reasonable manner." Quoted in Caplan, The Police Legal Advisor, 58 J. Crim. L.C. \& P.S. 803, 306 n.13 (1967). 185 TASK FORCE REPORT: THE POLYCE at 28-29. 
educative and moral effect of the exclusionary rule. "It is a terrible thing," one official told the author, "when we have to break the law to enforce the law."

Several observers have commented upon the unreality of expecting legal rules to exert effective control over the routine conduct of an individual officer. Albert J. Reiss, Jr. and Donald J. Black argue that conflict between the appellate courts and the police over behavior standards is inevitable since appellate court criteria for the exclusion of evidence "articulate a moral order-a system of values and norms_-" whereas "the police are organized to articulate a behavior system-to maintain law and order .... [T] heir organizational concern is less for the legitimacy of means than for the rather immediate end of enforcing behavior standards."186 James $Q$. Wilson's eight-city study of police behavior in the maintenance of order and the enforcement of less serious offenses revealed that the primary guides for a patrolman's behavior were the felt needs of the situation and the expectations of his colleagues on the beat. The patrolman is oriented to approach incidents that threaten order not in terms of enforcing the law but in terms of "handling the situation." 187

The individualistic, rule-oriented perspective of the courtroom is at variance with the situational, order maintenance perspective of the patrolman. The patrolman senses this conflict without quite understanding it and this contributes to his unease at having his judgment tested in a courtroom. ${ }^{188}$

Skolnick gives the familiar example of a police officer who makes an illegal search that uncovers an unlawful weapon or narcotic. Even if the evidence is suppressed in court, the officer, through the act of retrieval, would have fulfilled his duty to confiscate illegal substances.

By failing to make the putatively "unreasonable" search, the policeman would not only have failed to gain a conviction,

186 Reiss \& Black, Interrogation and the Criminal Process, 374 ANNALs 47, 48-49 (1967). $187 \mathrm{~J}$. Wirson, supra note 140 , at chs. 1, $2,9$.

188 Id. at 31-32. A Crime Commission study of the attitudes of 204 police officers in high-crime precincts in Boston, Chicago and Washington provides evidence of the difference in outlook. Over half complained that Supreme Court decisions created problems in the search of persons or the seizure of evidence. An even $90 \%$ stated that the Supreme Court "had gone too far" in making rules favoring and protecting criminal offenders. Almost all of these cited one of the following reasons for their opinion: curtails effectiveness of police work, helps criminals or fails to protect society or victims of crime. A quarter of the officers interviewed stated that changes in courts or court decisions was the most important thing that could be done to reduce crime in their district. Reiss, Career Orientations, Job Satisfaction, and the Assessment of Law Enforcement Problems by Police Officers, 2 Studies in Crime and Latw Enforcentent in Major Metropolitan Areas $\S 2$, at $68,110,112-3(1967)$. 
but would also have missed collecting objects or substances regarded as dangerous. In the policeman's view, only good can come out of a search legally defined as "unreasonable," provided the search jibes with the normative assumptions of the police organization about reasonableness. ${ }^{189}$

It is said that the courts have not been sufficiently informed and sensitive to the practical needs of law enforcement. ${ }^{190}$ However that may be, it seems likely that judicial review by means of the exclusionary rule does not have a reforming effect over competing norms of police behavior in many areas. The operation of the rule is not suited to that purpose. The rule arises out of a review of the conduct of an individual officer, not a challenge to a policy of the department. The court is generally unaware of the relevant department policy, and by no stretch of the imagination can it be said to have reviewed it. And the ultimate sanction, loss of the prosecution, affects the department even less than the officer himself. ${ }^{191}$

4. Reinforcement by a Sense of Moral Obligation. It should be apparent from the foregoing discussion that the exclusionary rule is not reinforced by a comprehensive sense of moral obligation, at least as regards its potential for direct deterrence. Over the long term, however, the moral and educative force of the exclusionary rule may wear away at the competing norms so that the rule may ultimately be reinforced by a sense of moral obligation.

5. Motivation for Prohibited Act. The strength of the motivation to

$189 \mathrm{~J}$. SkolNick, supra note 91 , at 220.

190 The Challenge of Crime at 94. Speaking from the findings of the American Bar Foundation's survey and from their own observation, LaFave and Remington declare:

"Hearings on motions to suppress evidence allegedly obtained by illegal police investigative practices are often conducted in a manner not calculated to encourage careful consideration of the factual and legal bases for the motion. . . .

"As a consequence, trial courts rarely are given an accurate or complete picture of the law enforcement practice challenged by the motion to suppress."

LaFave \& Remington, supra note 29, at 1003-4.

191 The Crime Commission's Task Force Report on The Police describes the problem in this way:

Most often, the process of judicial review is seen as a decision about the propriety of the actions of the individual officer rather than a review of departmental administrative policy. Judges seldom ask for and, as a consequence, are not informed as to whether there is a current administrative policy. And, if there is one, they seldom ask whether the officer's conduct in the particular case conformed to or deviated from the policy. As a result, police are not encouraged to articulate and defend their policy; the decision of the trial judge is not even communicated to the police administrator; and the prevailing police practice often continues unaffected by the decision of the trial judge.

TASK FORCE REPORT: THE POLICE at 31. The Report urges that conformity to approved standards of behavior is more likely to be attained by changes in department rules, so it urges courts to place greater emphasis on reviewing departmental policies that may be responsible for the behavior that causes evidence to be suppressed. Id. at 20, 32-33. 
engage in the prohibited conduct and the availability of alternative ways to attain the desired goal will of course vary widely. Sometimes there will be a strong motivation, such as that provided by the officer's instinct of self-preservation in the search for a weapon or his desire to win plaudits for the recovery of stolen property that can be retrieved only by an illegal search. Sometimes alternative courses will be available, such as easy access to a warrant; but sometimes-if responsible police officers are to be believed-there is no practical way to proceed except upon the illegal course. This subject does not admit of easy generalization, except that there will be circumstances when the conditions for the general deterrent effect of the exclusionary rule are very negative.

6. Effective Communication. To be an effective general deterrent the sanction and the reasons for the sanction must be communicated to the target population. There is reason to believe that the channels of communication between police and courts and prosecutors are such as to minimize the deterrent effect of the rule. On the basis of the American Bar Foundation's field research survey of the administration of criminal justice, supplemented by their own observation, Wayne R. LaFave and Frank J. Remington give the following description:

Nor are police well informed about the trial judge's decision or its legal basis. The trial judge seldom explains his decision in a way likely to be understood by the police officer, and the prosecutor assigned to the case rarely assumes it to be his duty to inform the police department of the meaning of the decision or of its intended impact upon current police practice. The individual officer whose case has been lost is not expected to report the reason for the decision to his superiors. Some decisions, usually those the officer believes to be particularly outrageous, may be passed on to other officers by word of mouth, but they often become distorted in the retelling. If a 'court officer' is assigned to the court by the police department, his responsibilities do not include reporting the judge's rulings on police conduct. Obviously, police cannot be affirmatively influenced to change their methods of law enforcement by the exclusion of evidence when there is no communication to them of why the decision was made. ${ }^{192}$

This description is confirmed in all respects by the author's summer 1964 observations while working as an Assistant States Attorney as- 
signed to the Chicago courts where most suppression hearings were held. ${ }^{103}$

7. Clarity of the Rule. The deterrent effectiveness of the exclusionary rule is also dependent upon whether the arrest and search and seizure rules that it is supposed to enforce are stated with sufficient clarity that they can be understood and followed by common ordinary police officers. This point applies not only to the direct deterrent effect of the rule, but also to its longer range moral and educative effect. If the rules are a clarion call for protecting the rights of the individual, then the trumpet gives an uncertain sound. ${ }^{194}$ Though undoubtedly clear in some areas of police behavior, the rules are notoriously complex in others. As one critic observed with acid hyperbole, they "would not deter or enlighten a policeman in Gary with a $\mathrm{Ph}$.D. who was going to law school at night."105 At the very least it can be said that in terms of the complexity of the rules, the area of arrest and search and seizure is not a favorable one for a deterrent sanction to be effective.

The point of this section is not that the exclusionary rule can have no direct deterrent effect. There are probably situations where it deters. In crimes such as homicide, where prosecution is almost a certainty and where public interest and awareness are high, the conditions for deterrence are optimal and the exclusionary rule is likely to affect police behavior. ${ }^{106}$ The point of this section is, rather, that there are situations-and there are good reasons to believe that these situa-

193 In the author's observation, Assistant States Attorneys rarely communicated with individual police officer witnesses to explain what they had done wrong and why their evidence was being suppressed. Inquiries by the author found a significant fraction of patrolmen who were leaving the courtroom confused and bitter about the action taken, attributing it to venality of the judges or prosecutor (or both), and having no idea whatever of how to modify their own conduct to avoid a repetition. (Such misunderstandings were not observed in experienced detectives.) The police sergeants assigned to each court stated that they had no responsibility to (and did not) inform the Department of instances when a police officer had violated the arrest and search and seizure rules. They did not discuss the reasons with the individual officer or relay any impressions to the Training Division.

194 "For if the trumpet give an uncertain sound, who shall prepare himself to the battle?" I Cor, 14:8.

195 Burns, supra note 30, at 100. Sceptics on the issue of complexity should consult, inter alia, LaFave, Search and Seizure: "The Course of True Law . . Has Not . . . Run Smooth," 1966 ItL. L.F. 255.

190 Thus, after weeks of observing police in action, Skolnick concluded that "the exclusionary principle puts pressure on the police to work within the rules in those cases where prosecution is contemplated." He also concluded that "the rule seems to control police almost in direct relation to the gravity of the crime of the suspect." J. SKolNick, supra note 91 , at $224,225$. 
tions comprise a majority of law enforcement activities involving arrest and search and seizure-where conditions militate against the direct deterrent effect of the exclusionary rule. ${ }^{197}$

Empirical Research. The foregoing discussion involved a large variety of factual questions subject to empirical examination. Most are set out here in outline form.

(A) What penalizing effect does the application of the exclusionary rule have upon an individual law enforcement officer?

(1) Is the mere fact of exclusion looked on by the officer as a penalty upon him, by rendering his enforcement efforts fruitless or by officially declaring that he has wasted his time in court? This question might be explored by some form of attitude research.

(2) What, if any, disciplinary or administrative review or police command pressure is applied to correct the behavior of an officer who occasionally or repeatedly engages in violations of the arrest and search and seizure rules that result in suppression of evidence in court? Police records would reveal formal disciplinary incidents and routine procedures for administrative review, but the important informal pressures probably could be ascertained only by careful observation or by frank disclosures by police personnel. ${ }^{198}$

(B) If an application of the exclusionary rule brings pressure on the prosecutor, is the prosecutor in a position to pressure and does he in fact pressure the police to correct the improper practice? ${ }^{199}$

$197 \mathrm{~J}$. SKolNick, supra note 91, at 224, concludes:

Consequently, all these reasons-the norm of police alertness; the requirement that police confiscate illegal substances; the tendency toward a presumption of the legality of the search once the illegal substance is found; the fact that in a small pinch the policeman is usually not interested in an arrest but in creating an informant; the fact that the defense will be impressed by the presence of incriminating evidence; the sympathy of police superiors so long as policemen act in conformity with administrative norms of police organization; the difficulty of proving civil suits for false arrest; the denial of fact by the exclusionary rule; and the problematic character of what behavior is permitted when justification may appear to a court to be "uniquely present"-militate against the effectiveness of the exclusionary rule. In short the norms of the police are fundamentally pragmatic. Since the policeman has everything to gain and little to lose when he uses the 'reasonableness of the search and seizure' standard in small cases, he does so, even though this is not the prevailing legal standard.

But compare Chambliss, Types of Deviance and the Effectiveness of Legal Sanctions, 1967 WIs. L. REV. 703, 712, for a theoretical discussion upon which one may conclude that police officers are among the groups most likely to be deterred by legal sanctions.

198 " $[\mathrm{I}] \mathrm{n}$ the absence of better information, even unverified gossip can sometimes serve a useful purpose. Its utility lies in isolating potential problems and in guiding analysis, rather than in measuring the extent of the problems it suggests." Alschuler, supra note 165 , at 52 n.15.

199 See generally Katz, supra note 67, at 142 . 
(1) Does the prosecutor have any formal authority over the police? This question can be answered by studying the formal or legal structure of government. In addition, one could usefully compare the command relationship between prosecutor and police in Canada and other Commonwealth countries. ${ }^{200}$

(2) What, if any, indirect authority does the prosecutor have, or try to exercise, over the police?

(3) How frequently do prosecutors institute criminal proceedings against police officers for offenses (such as battery, breaking and entering or trespass) committed in the course of an improper search and seizure? This could be determined from official records. In addition, one might also compare the record of prosecutors in common law jurisdictions like Canada that rely on methods other than the exclusionary rule for control of police behavior.

(C) How effectively are the applications of the exclusionary rule communicated to the erring officer and to the target population that is supposed to be the object of its general deterrent effect?

(1) What, if any, measures are actually taken to assure that the officer whose conduct has caused the suppression understands where he erred and how he could avoid repetition of the error?

(2) What, if any, measures are taken to keep police department command personnel informed of the type and extent of arrest and search and seizure violations that cause suppression of evidence? To what extent are these facts and related departmental instructions communicated to line officers?

(D) To what extent is the impact of the exclusionary rule neutralized by competing norms of police behavior (formal or informal)? The Skolnick, Wilson and LaFave books and the Crime Commission's Task Force Report on the Police have already done considerable observation in this area. No better method appears at present. There is need for further work to identify and establish the frequency of police practices that are both conventional and contrary to the rules of arrest and search and seizure.

(E) In what types of situations and to what extent is the effect of the exclusionary rule reduced by strong motivations to engage in the illegal behavior and by the absence or believed absence of an acceptable alternative to attain the desired goal? This is another subject for 
which the best available method of inquiry appears to be intensive participant observation. ${ }^{201}$

\section{G. Effect of the Standing Requirement}

The direct deterrent effect of the exclusionary rule may be reduced by limitations on the scope of the rule. Some of these limitations have recently been removed, ${ }^{202}$ but an important one remains. Courts employ the exclusionary rule only at the behest of a person who has "standing" to make the motion to suppress. A person has standing only if he was aggrieved by the unlawful search and seizure, such as one whose person was searched, whose property was seized, or who was a rightful occupant of the place where it was seized.203 A person has no standing to invoke the exclusionary rule if the evidence was obtained through an unlawful invasion of the rights of some other person (such as a co-conspirator or accomplice), even though the evidence is being used to attempt to convict him of a crime. ${ }^{204}$

The standing limitation is inconsistent with both of the asserted reasons for the exclusionary rule, the so-called "imperative of judicial integrity" and the desire to deter the police. ${ }^{205}$ If the exclusionary rule were seriously bent on deterring the police or on avoiding judicial involvement in illegal behavior it would exclude all illegally seized evidence, without inquiry into whose property or personal rights were violated. Upon this reasoning numerous writers have urged abolition of the standing requirement, ${ }^{208}$ but thus far only the California Supreme Court has heeded their urgings. ${ }^{207}$ The United States Supreme Court recently adhered to its standing rule after thorough briefing and argument in a case where a defendant sought to exclude wiretap evidence obtained by illegally invading the rights of other

201 See text accompanying note 183 supra.

202 In Elkins v. United States, 364 U.S. 206 (1960), the Supreme Court upset the "silver platter" doctrine, which had permitted federal officers to use evidence obtained illegally by state officers. More recently, the Supreme Court set aside earlier holdings that the exclusionary rule did not apply to civil forfeiture proceedings. One 1958 Plymouth Sedan v. Pennsylvania, 380 U.S. 693 (1965).

203 Jones v. United States, 362 U.S. 257 (1960); T. AввoTT, et al., supra note I, at ch. 4; White \& Greenspan, Standing to Object to Search and Seizure, 118 U. PA. L. Rxv. 333 (1970); Comment, supra note 20. Standing will be assumed if the defendant would have to prove his guilt of the crime in order to establish his standing. Id. An example would be narcotics seized and intended to be used as evidence in a prosecution for possession of narcotics.

204 Alderman v. United States, 394 U.S. 165 (1969); authorities cited note 203 supra.

205 Allen, supra note 11, at 22; Comment, supra note 20, at 347, 349, 358.

208 See, e.g., Allen, supra note 11, at 22; Traynor, supra note 25, at 335; authorities cited in Comment, supra note 20, at 343 n.8.

207 People v. Martin, 45 Cal. 2d 755, 290 P.2d 855 (1955) (Traynor, J.). 
persons. The opinion in Alderman $v$. United States ${ }^{208}$ displays a clear unwillingness to follow the exclusionary rule to its logical conclusion when this would further encroach upon the public interest in having convictions or acquittals upon the basis of all evidence that exposes the truth.

The necessity for [the standing rule] was not eliminated by recognizing and acknowledging the deterrent aim of the rule. [Cites Linkletter and Elkins cases.] Neither those cases nor any others hold that anything which deters illegal searches is thereby commanded by the Fourth Amendment. The deterrent values of preventing the incrimination of those whose rights the police have violated have been considered sufficient to justify the suppression of probative evidence even though the case against the defendant is weakened or destroyed. We adhere to that judgment. But we are not convinced that the additional benefits of extending the exclusionary rule to other defendants would justify further encroachment upon the public interest in prosecuting those accused of crime and having them acquitted or convicted on the basis of all the evidence which exposes the truth. ${ }^{209}$

The Supreme Court's adherence to the standing limitation continues an unstable truce between two concepts that are logically at war with one another. In the long run one or the other will probably give way. In the meantime, the exclusionary rule may have diminished deterrent effect against illegal searches and seizures directed at property not belonging to or in the possession of the prospective defendant. ${ }^{210}$

Empirical Research. Apart from one relatively unimportant inquiry, ${ }^{211}$ the standing exception does not seem to be a fruitful subject for empirical research. It might be useful to inquire into whether and the extent to which police deliberately take advantage of the standing

208394 U.S. 165 (1969).

$200 \mathrm{Id}$. at 174-5.

210 The exclusionary rule is also unlikely to discourage invasions of privacy by private parties, since the Supreme Court has made no move to modify rulings that the exclusionary rule does not prevent the use of evidence obtained by private parties under circumstances that would have been an unreasonable search and seizure if obtained by government officers. Burdeau v. McDowell, 256 U.S. 465 (1921).

211 The recent adoption of the exclusionary rule for civil forfeiture proceedings (note 202 supra) offers an opportunity for a relatively current before-after study of the deterrent capacity of the rule. The object would be to determine what, if any, changes in the degree of adherence to search and seizure rules in civil forfeiture matters followed adoption of the exclusionary rule. Forfeiture proceedings are probably limited to a few crimes, of which smuggling and narcotics violations are probably the most prominent. The inquiry could include an examination of the frequency and pattern of such proceedings and their relationship to any criminal prosecutions against the same parties. 
loophole to obtain evidence that can be used in court even though acquired by illegal means. If the police were measurably less inhibited in this area than where there was standing, then this would tend to confirm the deterrent capacity of the exclusionary rule. It seems doubtful that such confirmatory evidence could be obtained. Most searches take place prior to the filing of criminal charges, before the police know who is and who is not to be a defendant in a particular criminal proceeding. As a practical matter, it is therefore unlikely that the standing rules have measurable effect upon police adherence to the arrest and search and seizure rules.

\section{Negative EFFects OF THE EXCLUSIONARY RULE}

This part will discuss some possible negative effects of the exclusionary rule. If these negative effects can be substantiated, they represent disadvantages or costs of the use of the exclusionary rule, whether or not the rule achieves its purpose of discouraging improper behavior by the police.

\section{A. Nothing for the Innocent, but Freedom for the Guilty}

In terms of direct corrective effect, the exclusionary rule only benefits a person incriminated by illegally obtained evidence. It does nothing to recompense the injury suffered by the victim of an illegal search that turns up nothing incriminating. Justice Robert Jackson expressed the point vividly:

Rejection of the evidence does nothing to punish the wrongdoing official, while it may, and likely will, release the wrongdoing defendant. It deprives society of its remedy against one lawbreaker because he has been pursued by another. It protects one against whom incriminating evidence is discovered, but does nothing to protect innocent persons who are the victims of illegal but fruitless searches. ${ }^{212}$

This point and its corollaries have often been urged in opposition to the exclusionary rule. Wigmore remarked upon how the exclusionary rules "serve neither to protect the victim nor to punish the offender but rather to compensate the guilty victim by acquittal and to punish the public by unloosing the criminal in their midst . . ." ${ }^{213} \mathrm{He}$ also

212 Irvine v. California, 347 U.S. 128, 136 (1954). See also Jackson, J., dissenting in Brinegar v. United States, 338 U.S. I60, 181 (1949); Wolf v. Colorado, 338 U.S. 25, 30 (1949) (Frankfurter, J.).

2138 WIGMORE ON EVIDENCE § 2184, at 51-52 (McNaughton ed. 1961). See also Wilson, Police Authority in a Free Society, 54 J. CRIM. L.C. \& P.S. 175, 177 (1963). 
complained that the rule compels courts to exchange the certainty of conviction for the possibility of protecting individuals by improving police practices. Monrad Paulsen has commented on the "startling result achieved under the rule: to deter the police both the guilty defendant and the law-breaking officer go unpunished."214

Francis A. Allen has argued that complaints about the exclusionary rule freeing the guilty seem to be "less an assault on the exclusionary rule than upon the validity of the substantive right sought to be protected by constitutional provisions forbidding unreasonable searches and seizures."215 But it is surely not at odds with complete devotion to the guarantee against unreasonable search and seizure to urge that the exclusionary rule is deficient in its failure to furnish direct protection to the innocent as well as to the guilty.

Monrad Paulsen has capsulized the second half of this argument in his statement that " $[t]$ he rule destroys respect for law because it provides the spectacle of the courts letting the guilty go free."216 This spectacle is bound to arouse the instinctive resentment that Edmund Cahn has called "the sense of injustice." It parallels two of the illustrations he provides:

[I]nequalities arbitrarily created arouse the sense of injustice, because equal treatment of those similarly situated with respect to the issue before the court is a deep implicit expectation of the legal order .... What it [the sense of injustice] cannot stomach is the use of law to raise up the guilty ....217

An application of the exclusionary rule to an improper search and seizure is probably more vulnerable to a complaint of "freeing the guilty" than the exclusion of an improperly obtained confession or eyewitness identification. Physical evidence is no less reliable when illegally obtained. The nature of burglary tools, blood stains, or white powder in a glassine wrapper is not changed by the circumstances of their acquisition. In contrast, identifications obtained by faulty lineup

214 Paulsen, supra note 58, at 256. Alfred Hill uses this shortcoming as a basis for suggesting greater flexibility in the means of enforcing the underlying constitutional right: "If the other remedies are as ineffective as claimed, this means that innocent victims of illegal searches and seizures are now substantially without recourse. Accordingly, there would be value in a new remedial 'mix' which, without overall loss of deterrence, operates so as to produce benefits for the innocent." Hill, supra note 25 , at 184-5 n.17.

215 Allen, supra note 11 , at 19.

216 Paulsen, supra note 58, at 256.

217 E. Cahn, The Sense of Injustice 14, 17 (Midland ed. 1964). See also Andenaes, General Prevention-Illusion or Reality?, 43 J. CrIM. L.C. \& P.S. 176, 183-4 (1952). 
procedures are of doubtful reliability. So are confessions obtained by coercive methods, though the Supreme Court no longer relies on that rationale and administers a rule that excludes confessions even if of proven reliability. ${ }^{218}$ In addition, under current law enforcement methods, evidence obtained by a search is likely to be vital to conviction in most types of crimes where searches are commonly involved (notably gambling, narcotics and weapons). Confessions are generally less vital. ${ }^{210}$ Thus, the application of the exclusionary rule to evidence obtained by improper search or seizure is specially vulnerable to the criticism of freeing the guilty because it excludes reliable (and often practically conclusive) evidence of guilt, and it frequently results in the immediate termination of the prosecution.

The most emphatic polemic on this point is that of the then Judge Warren E. Burger. After complaining that the important reasons underlying the exclusionary rule "are almost beyond comprehension to most laymen, including most police officers," he contrasted what they could observe about its effects:

The operation of the Suppression Doctrine unhappily brings to the public gaze a spectacle repugnant to all decent people-the frustration of justice .... If a majority-or even a substantial minority-of the people in any given community ... come to believe that law enforcement is being frustrated by what laymen call 'technicalities,' there develops a sour and bitter feeling that is psychologically and sociologically unhealthy .... I do not challenge these rules of law [applying the suppression doctrine]. But I do suggest that we may have come the full circle from the place where Brandeis stood, and that a vast number of people are losing respect for law and the administration of justice because they think that the Suppression Doctrine is defeating justice. That much of this reaction is due to lack of understanding does not mean we can ignore it . ...

The public has accepted-largely on faith in the Judiciary -the distasteful results of the Suppression Doctrine; but the wrath of public opinion may descend alike on police and

218 Kaufman v. United States, 394 U.S. 217, 224, 239 (1969). Other differences between the police conduct involved in confessions and in search and seizures are discussed in Mapp v. Ohio, 367 U.S. 643, 684-5 (1961) (Harlan, J., dissenting), and in Allen, supra note 3 , at $29-32$.

210 For evidence on the dispositive effect of motions to suppress see text at note 72 supra. High police officials in several areas advised the author that under present practice they rarely make any attempt to interrogate defendants to obtain confessions. A 1956-66 study in the District of Columbia showed that there were no ascertainable differences in conviction rates between cases where the defendant had given a statement and those where he had not. Crime in THE District of Columbis, supra note 179, at 605-8. 
judges if we persist in the view that suppression is a solution. At best it is a necessary evil and hardly more than a manifestation of sterile judicial indignation even in the view of well motivated and well informed laymen. We can well ponder whether any community is entitled to call itself an 'organized society' if it can find no way to solve this problem except by suppression of truth in the search for truth.220

Empirical Research. The assertion that the exclusionary rule makes no direct effort to recompense the innocent is axiomatic and requires no empirical demonstration.

There are several matters for factual inquiry in the argument that the rule diminishes respect for law by the spectacle of the courts letting the guilty go free. First, is it fair to assume that most defendants who succeed in having evidence suppressed are in fact guilty? A study and classification of the type of evidence actually suppressed in various kinds of crimes and a judgment about the likelihood of obtaining a conviction with and without this evidence would be helpful in answering this question.

Second, the question of the effect of this "spectacle" on the public image of the courts and on the elusive concept of "respect for law" is appropriate for study. There have been several public opinion surveys that disclosed considerable public dissatisfaction with the Supreme Court's use of "technicalities" to free guilty persons, ${ }^{221}$ but there is ample scope and need for further inquiry.

\section{B. Fostering False Testimony by the Police}

Skolnick's observations and the Columbia study both yield evidence of deliberately false testimony by the police. ${ }^{222}$ High-ranking police officers have admitted to the author that some experienced officers will "twist" the facts in order to prevent suppression of evidence and re-

220 Burger, supra note 56 , at $12,22,23$. Judge David $A$. Pine made similar arguments for the minority in the RePort of the PRESIDENT's CoMmission on CRIME IN THE DisTrict of Columbia 872-3 (1966). After stating that the tenor of some appellate decisions may be among the indirect causative factors of crime, he explained: "These court decisions ... have created, in my opinion, a climate hospitable to the belief that punishment of the guilty is far from certain and may be avoided by technicalities and loopholes in the law. ... I believe that when certainty of punishment is lacking by reason of technicalities, without regard to guilt, its prophylactic effect is substantially lessened, and the commission of crime is encouraged. Indeed, it is axiomatic that when law enforcement is weak and vacillating, disrespect for the law ensues, and crime begins to flourish."

221 E.g., Reiss, Public Perceptions and Recollections about Crime, Law Enforcement, and Criminal Justice, 1 Studies in CRIME and LAW ENForcement IN MAjor Metropolitan AREAs \& 1, at 81-85 (1967); Majority Say Courts 'Too Soft' on Criminals, The Gallup REPORT, March 3, 1968.

222 See text accompanying notes 85 \& 91 supra. 
lease of persons whom they know to be guilty. To use the words of one command level officer, the policeman is "programmed to respond so as to legalize an arrest." To the extent that police officers avoid the suppression of evidence by deliberate false testimony about the circumstances of arrest or search and seizure, the exclusionary rule not only fails to achieve its own objectives, it also corrupts law enforcement personnel and degrades the whole system of criminal justice.

Empirical Research. The examination of this effect will be complicated by the fact that police personnel will hesitate to cooperate since the facts being sought may discredit law enforcement agencies and expose individual officers to criminal liability. A few possible methods of inquiry and some information gathered by the author are described below.

1. Skolnick's work has shown that an observer who spends enough time with the police will have valuable insights of his own and may also, by winning confidence, be able to obtain disclosures that are unavailable to short term outside interviewers. The difficulty with this method is that it yields data that is difficult to quantify. It can determine whether or not some police twist the facts in some suppression hearings and it can identify some circumstances where this occurs, but it is unlikely to yield acceptably accurate information on the frequency of the practice.

2. The Columbia study demonstrated how information could be obtained by comparing changes in the reasons police gave for making arrests before and after adoption of the exclusionary rule. The difficulties with this method have already been discussed. ${ }^{223}$

3. Another indirect approach is suggested by Skolnick's observation that the police fabricate probable cause when they feel incapable of literal compliance with the arrest and search and seizure rules and therefore feel they must reconstruct the facts rather than allow the offender to escape punishment. This suggests that the situations where police fabrication is most likely to occur could be identified by the inquiry, suggested earlier, ${ }^{224}$ which would identify the arrest and search and seizure rules that the police consider most burdensome or the factual situations or crimes where they feel the rules to be most inhibiting.

4. It might be possible to obtain police cooperation for one type of interviewing that could yield useful data. Police officers who have made numerous arrests for a type of crime that often involves motions 
to suppress could be shown a list of possible factual situations that could result in arrest without warrant, and asked to estimate the proportion of their own arrests involving each type of situation. ${ }^{225}$ After this information was gathered from an officer, the researcher could examine the police reports and court files in all cases within a particular period involving this particular officer, and compare the profile of facts set forth in those files with the profile of facts described by the officer. Significant disparities may indicate falsification of testimony, and analysis may indicate even the patterns of falsification.

5. Another method is available if a researcher can win the cooperation of police supervisory personnel. An experienced officer could examine the testimony given in court suppression hearings or the account recorded in official police arrest reports in a large number of cases involving a particular charge and estimate the proportion and identify the types of twisting of facts in those cases. Experienced police officers have advised the author that they felt they could do this with considerable accuracy, since instances of fabrication fall into relatively familiar patterns in various offenses, and an experienced officer can recognize those patterns. ${ }^{226}$

6. If assured anonymity, ranking police officers with sufficient field experience may be willing to make quantitative estimates of the extent of police fabrication and describe the circumstances in which it occurs.

One official did this for the author. After many requests and a prolonged series of conferences, a command level official from a large metropolitan police department gave the author the following description of the nature and extent of police "twisting" of facts in suppression hearings, based on his observation. Fabrication occurs in two types of situations. First, where a patrolman has made an on-view arrest and officers of a special detail can reach the scene before he has submitted his written report, they assist him in submitting a report that will not prevent a conviction under some rule of an appellate court. The official gave this example: Suppose a patrolman had pursued a person whom he had seen leaving the scene of a crime, he lost sight of him for a minute's time, and then he discovered him hiding in an obscure loca-

225 For example, the factual classifications used in the Columbia study, text accompanying note 85 supra, would be suitable for narcotics arrests. The question should make clear that the desired answer is what actually happened, whether or not the true facts came out in court. The officer would not be asked how he or his fellow arresting officer testified in court, or about the names of defendants in any case or group of cases.

226 For example, one high-ranking police official told the author that his officers "almost invariably lie about [their conformity with] the no-knock rule [which requires an announcement of authority and purpose before forcing entry in a private dwelling] because it affects their personal safety." 
tion. The patrolman's report would be prepared to contain the words "never losing sight of the defendant ...." The officer estimated that this type of twisting of facts occurred in about one-third of the cases where special detail officers assisted patrolmen with their reports.

The second type is a direct fabrication of probable cause for an arrest and search. The police stop and search a motor vehicle and its occupants. If they discover the proceeds or implements of a crime, such as stolen goods, burglary tools or a weapon, they "hang a traffic offense on him afterward to ice it up, and they say the [evidence] was in plain view on the floor when it was really under the seat." The official stated that if the defendant is a known professional thief, this type of fabrication happens about 98 per cent of the time. (He estimated that professional thieves comprise about 20 per cent of the on-view arrests.) If the defendant is not a professional thief, the facts are "rarely" twisted in this manner. ${ }^{227}$

7. In defense of law enforcement personnel, it is fair to add that what appears as fabrication to a layman may in reality be a policeman's honest perception of facts, viewed in the light of his trained observation and intuition. This observation might be tested by showing a movie of an arrest-type situation to laymen and to trained police officers and comparing what each observed. It is possible that entirely without conscious twisting of the facts, the officers may observe more facts that contribute to a finding of probable cause for arrest than the laymen.

\section{G. Delay and Diversion from the Question of Guilt or Innocence}

It is said that the exclusionary rule hampers the administration of justice by delaying a criminal proceeding and by diverting its focus from the guilt or innocence of the defendant. Monrad Paulsen summarized this negative effect:

The [exclusionary] rule attempts to redress a violation of law without the time-honored method of direct complaint

227 Cf. J. SkolNick, supra note 91, at 215: "[T] to construct an ex post facto description of the preceding events so that these conform to legal arrest requirements, whether in fact the events actually did so or not at the time of the arrest."

The official who made the above disclosures stated that the kind of twisting of testimony described above was never done to "get" a person who was innocent, or to convict any person about whose innocence there was any doubt. He further observed that professional criminals hire expensive counsel, rarely plead guilty, are exceedingly difficult to convict, and get comparatively short sentences. In contrast, the "little guy" who is arrested for the same crime is typically young, unable to afford good counsel, easy to persuade to plead guilty, and likely to receive a longer sentence. He observed that the police conduct he described helps to rectify that discrimination. 
and trial on a carefully defined issue. The procedure looking toward exclusion of evidence interrupts, delays, and confuses the main issue at hand-the trial of the accused. The principal proceeding may be turned into a trial of the police rather than of the defendant. ${ }^{228}$

These objections are familiar ones. Wigmore made them, and so have others. ${ }^{229}$ "To the patrolman," James Q. Wilson has observed, in describing tensions between police and judges and lawyers, "it appears that he and not the defendant is on trial." 230 A criminal prosecution of one person is at least an indirect and awkward forum for inquiring into the behavior of some other person, a police officer, with a view to punishing him or creating some deterrent against similar conduct in the future. And there is something anomalous if not downright distasteful in the spectacle of a judicial officer engaging in what Chief Justice Burger has sternly characterized as the "suppression of truth in the search for truth." 231

Empirical Research. The factual questions under this point are the extent to which criminal proceedings are delayed, diverted or rendered less efficient by motions to suppress or other proceedings to implement the exclusionary rule. There are ample opportunities for reliable and relatively simple empirical research on these questions. Caution must be exercised in generalizing from such research, however, since these are matters on which differences in the criminal justice systems of different areas can have a considerable effect on the outcome of the research. For example, the exclusionary rule's potential for delay and diversion would seem to be greater in a system like Chicago's, where the search and seizure issues are almost invariably litigated in court, than in a system like the District of Columbia's where prosecutors review and screen out the most egregious cases in advance of court hearing. The Chicago data set out below is not tendered as typical of courts generally, but only as expressive of the probable upper limit of delay and diversion at this stage of the criminal justice system.

1. Time Spent on Motions to Suppress. How much courtroom time is spent on motions to suppress in various types of crime? What fraction of the total courtroom time is spent in this manner? Tables 10 and 11 show the time spent on motions to suppress in the two municipal branches that hear about 80 per cent of the motions to suppress

228 Paulsen, supra note 58, at 256-7.

220 WIGMORE, supra note 213, at 51-52; Barrett, supra note 37 , at 591.

$230 \mathrm{~J}$. Wuson, supra note 140, at 52.

231 Quoted in text at note 220 supra. 
in Chicago. ${ }^{232}$ The Narcotics branch receives all Chicago narcotics offenses (about 60 per cent of its cases fit in this category) and all other offenses, whatever their nature, that involve defendants with a background of narcotics offenses. The Rackets branch is assigned all gambling cases (about one-third of its business), a high proportion of the weapons cases (about one-third of its business), and a variety of other offenses, predominantly disorderly conduct and theft. The following data was gathered by an observer who made one week's continuous observation with a stop watch in each courtroom.

It appears from Tables 10 and 11 that motions to suppress accounted for 20 per cent of the courtroom time in the Rackets branch and 34 per cent of the courtroom time in the Narcotics branch. The actual time expended amounted to about 13 hours per week. If this total is increased by one-fourth for the proportion of motions to suppress heard in other courtrooms, then the total time expended on motions to suppress is about 5 per cent of the total time expended in all fourteen municipal department courtrooms that hear misdemeanors and hold preliminary hearings in felonies in Chicago. If the hours of the Criminal Division judges holding trials in felony cases are considered, the total is about 3 per cent. Either figure is a paltry proportion of the total courtroom time devoted to criminal cases in Chicago.

Considered only against the time spent on particular crimes, the motion-to-suppress time is of course much more significant. The 20 per cent figure is probably a good measure of the fractional time spent on motions to suppress in weapons and gambling cases, since those two categories comprise about equal proportions of the docket in Rackets court, and there were motions to suppress in about the same proportion of cases in each category. The proportion of total courtroom time devoted to narcotics cases that is spent on motions to suppress is probably higher than the 34 per cent figure for the whole Narcotics branch. This is because there is a materially higher propor-

232 An examination of all motions to suppress disposed of during twelve sample days in 1969 in all 14 Chicago municipal department courtrooms hearing criminal cases revealed the following:

Motions to Suppress in Chicago During Twelve

Sample Days in 1969

Motions in the Branch 27 (Rackets)

Motions in the Branch 57 (Narcotics)

Number

341

186

Per cent

Motions in all other Branches of the

Municipal Department in Chicago

122

Motions in the Criminal Division (Felony)

Totals

$\frac{1}{650}$

19

$\frac{1}{650}$

100

Source and sample days: Same as Table 3. 
TABLE 10

Courtroom time During Week in Branch 57 (Narcotics) of Circuit Court in Chicago (IN Minutes)

\begin{tabular}{lrrrrrrr}
\hline \multicolumn{1}{c}{ Activity } & Mon. & Tues. & Wed. & Thur. & Fri. & Total & Per cent \\
\hline Bond \& Continuances & 90 & 65 & 74 & 60 & 75 & 364 & 27 \\
Motions to Suppress & 84 & 108 & 72 & 64 & 133 & 461 & 34 \\
Probable Cause Hearing & 26 & 37 & 35 & 74 & 5 & 177 & 13 \\
Trial of Misdemeanor & $\mathbf{5 1}$ & 19 & 83 & 25 & 34 & 212 & 15 \\
Other & $\mathbf{3 1}$ & $\mathbf{2 4}$ & $\mathbf{3 1}$ & 43 & $\mathbf{2 7}$ & $\mathbf{1 5 6}$ & 11 \\
Total & $\mathbf{2 8 2}$ & $\underline{253}$ & $\underline{295}$ & $\underline{266}$ & $\underline{274}$ & $\underline{1370}$ & $\underline{100}$ \\
\hline
\end{tabular}

Period: Jan. I5 through Jan. 23, 1970; Judge Fred G. Suria, Jr. Data gathered by Kent Madsen, whose assistance is gratefully acknowledged.

\section{TABLE 11}

Courtroom Time During WeEk in Branch 27 ("RAckets") of Circuit Court in Chicago (IN Minutes)

\begin{tabular}{lrrrrrrr}
\hline \multicolumn{1}{c}{ Activity } & Mon. & Tues. & Wed. & Thur. & Fri. & Total & Per cent \\
\hline Bond \& Continuances & 60 & 92 & 32 & 86 & 54 & 324 & 22 \\
Motions to Suppress & 39 & 73 & 95 & 84 & 13 & 304 & 20 \\
Probable Cause Hearing & 10 & 0 & 15 & 3 & 0 & 28 & 2 \\
Trial of Misdemeanor & 102 & 154 & 237 & 52 & 98 & 643 & 43 \\
Other & 48 & 28 & 36 & 15 & 68 & 195 & 13 \\
Total & 259 & $\underline{347}$ & $\underline{415}$ & $\underline{240}$ & $\underline{283}$ & $\underline{1494}$ & $\underline{100}$
\end{tabular}

Period: Jan. 26 through Jan. 30, 1970; Mon., Wed. \& Thur. data for main courtroom, Judge Paul F. Gerrity; Tues. \& Fri. data for rear courtroom, Judge Lawrence Genesen.

tion of motions to suppress in narcotics cases than in the other categories of business heard in this court. ${ }^{233}$

In sum, more than one-third of the courtroom time spent on narcotics offenses in Chicago is devoted to hearings on motions to suppress. The comparable figure for gambling and weapons cases is about one-fifth. Since these three offenses account for about 80 per cent of the motions to suppress in Chicago (Table 3), it is unlikely that there is any other category of crime where motions to suppress occupy more than a negligible proportion of the total courtroom time spent on the offense. And the motion to suppress accounts for no more than about 3 per cent of the total courtroom time devoted to criminal cases in Chicago.

2. The Dispositive Effect of Motions to Suppress. One measure of the extent to which the motion to suppress diverts a criminal proceeding from the central question of the guilt or innocence of the

233 There were motions to suppress in 34\% of the narcotics cases and in only $7 \%$ of the other cases disposed in the Narcotics branch on these sample days. 
defendant is the extent to which the granting of motions to suppress results in final disposition of the charges in various offenses. Where the proportion is relatively high for a particular crime, the prosecution of that crime is bound to focus primarily on the arresting officer's conduct.

Table 5 presented the following figures on the proportion of defendants in the Narcotics and Rackets branches (which account for 80 per cent of the motions to suppress in Chicago) who have a motion to suppress granted in their case:

$\begin{array}{lc}\text { Chicago Defendants with Motion to Suppress } & \text { Granted } \\ \text { Gambling } & 59 \% \\ \text { Keeper of Gaming House } & 45 \% \\ \text { Lesser Gambling Offense } & 38 \% \\ \text { Average for all Gambling Offenses } & 45 \% \\ \text { Carrying Concealed Weapons } & 24 \% \\ \text { Narcotics } & 33 \%\end{array}$

These figures are long standing. Data from 1950 and 1964 studies cited earlier $^{234}$ showed comparable percentages for each of these offenses. The important fact to add at this point is that in every single one of these cases in which a motion to suppress was granted, the charges were then dismissed. The motion to suppress was therefore the dispositive event in about half of all gambling cases, one-third of all narcotics cases, and one-fourth of all weapons cases in Chicago. Those fractions are large enough that proceedings for violations of these types of crimes are bound to be focused largely upon issues pertinent to suppression of evidence, rather than upon issues pertaining to the guilt or innocence of the defendant. These are the only crimes in Chicago for which this is likely to be true, for there are no others where the motion to suppress is so prominent.

Tables 6 and 7 show that the per cent of defendants who are dismissed after granting a motion to suppress is only one to four per cent in the District of Columbia, where prosecutor screening eliminates cases in which a motion to suppress is likely to be granted. These figures show that the motion to suppress probably uses only a tiny fraction of the courtroom time in the District, and that its effects upon the overall outcome of cases are so negligible that it is unlikely to divert the attention of participants from the question of guilt or innocence. The interesting question for the District concerns the performance of the prosecutor's screening function and the possible effect of the motion to suppress upon delay or diversion at that point. 


\section{Side Effects on the Criminal Justice System}

The exclusionary rule is said to produce other undesirable side effects on the criminal justice system. This subject is enormously complicated, requiring systems analysis techniques to confront a host of uncertainties about the cause of changes in the system. ${ }^{235}$ The best that can be done at this point is simply to suggest some possible negative side effects of the exclusionary rule, without pretending to specify empirical methods by which they could be tested.

1. Changes in Substantive Rules. Edward L. Barrett, Jr. has argued that "the exclusionary rule creates pressure upon the courts to weaken the rules governing probable cause to make an arrest . . . where an obviously guilty defendant is seeking to exclude from consideration at his trial clear physical evidence of his guilt."236 Wigmore cited the same point as a possible "collateral perverse effect" of the exclusionary rule, though he admitted that it was difficult to demonstrate. ${ }^{237}$ In support of his thesis that the Supreme Court "is in retreat from implementation of its system of constitutional criminal procedure," Edmund W. Kitch cites a tendency to modify the content of the constitutional right to security from unreasonable search and seizure according to what can realistically be enforced by means of the exclusionary rule. ${ }^{238}$ "It is all a bit backward," 239 he observes.

The assertions and fears of Professors Wigmore, Barrett and Kitch are best approached in terms of expert analysis of judicial opinions. It is doubtful that they can be tested empirically.

2. Delay. In areas like the District of Columbia, where motions to suppress are noted for special hearing, such motions may be responsible for some delay in the disposition of individual cases. A study of 1165 criminal cases disposed of in the District of Columbia in 1965 showed that the average time between arraignment and final disposition was 9 weeks for defendants who filed no pretrial motions, 14 weeks for those who filed one motion, and 19 weeks (more than twice as long) for those who filed two or more motions. ${ }^{240}$ Only some of these

235 For a sample of the difficulties see D. OAks \& W. Lehman, supra note 73, at ch. 4 (discussing changes in frequency of guilty pleas and acquittals at trial).

236 Barrett, supra note 155 , at 55.

237 WIGMORE, supra note 213 , § 2184 , at 52 n.44.

238 Kitch, supra note 24 , at $157,157-72$.

239 Id. at 166.

240 Taylor, Navarro \& Cohen, Data Analyses and Simulation of the District of Columbia Trial Court System for the Processing of Felony Defendants 7 (Institute for Defense Analyses 1968). These figures were for the 910 defendants who pleaded guilty or were disposed without trial. There were comparable increases for the 255 defendants whose cases were tried: 14,18 and 23 weeks, respectively. 
pretrial motions were motions to suppress. There is need for a separate study to determine the separate delaying effect, if any, of motions to suppress.

3. Guilty Pleas and Sentencing. The exclusionary rule can have an important effect upon the timing and substance of guilty-plea bargaining and related sentencing decisions, especially in areas where bargaining occurs before the motion to suppress is litigated. Albert W. Alschuler suggests that the exclusionary rule has intensified plea bargaining in a number of ways. ${ }^{241}$ If the prosecutor is persuaded that the defense may prevail on a motion to suppress, he is likely to try to eliminate the risk of dismissal or acquittal by offering a favorable sentencing recommendation to induce the defendant to plead guilty. Even a motion that the defense is likely to lose presents a threat to the scarce time resources of the prosecutor. The resolution of pretrial motions to suppress and the briefing and argument of the appeals that often result from their denial cut into the prosecutor's time and increase the backlog of cases. In order to keep this backlog under control the prosecutor makes attractive sentencing recommendations to obtain a higher proportion of guilty pleas. Knowing the favorable effect of such pressure, defense counsel use the pretrial motion to suppress to threaten the court and prosecutor with added delay, in order to force a more favorable "deal." Thus, in areas where plea bargaining may occur before the motion to suppress is litigated, the end result of the exclusionary rule is thought to be lower sentences for persons who would have been convicted anyway, and a guilty plea and sentence of some persons, including some who are innocent, who would have gone free if the motion had been litigated and won. ${ }^{242}$ If so, this raises serious doubts about the fairness to society and to the defendant of a system that accepts a guilty plea before a motion to suppress has been resolved. Alleged infringements of vital constitutional rights ought not be the occasion of reduced sentences that give a discount to the guilty and an almost irresistible bargain to those who probably could not be convicted. In this respect, a prior hearing on motions to suppress (the usual practice in Chicago) seems preferable. The United States Supreme Court recently passed an opportunity to require this method when it refused to set aside a guilty plea on the ground that it had been

241 These suggestions appear in Alschuler, supra note 165, at 50,56, 80-82, and were further amplified for the author by personal conversations with Alschuler and by examination of some pages of an unpublished manuscript by him.

242 For another suggestion that the "due process revolution" may be having the unintended effect of reducing overall sentence length and inducing guilty pleas by some persons who could not be convicted, see D. OAks \& W. LEHMAN, supra note 73, at 80-81. 
induced by a prior involuntary confession. ${ }^{243}$ The reasoning apparently also covers guilty pleas allegedly induced by evidence obtained by an improper search and seizure.

The numerical importance and current interest in the question of plea bargaining and sentencing should be a strong incentive for empirical inquiry to determine the true relationship between these subjects and the exclusionary rule. ${ }^{244}$

\section{E. Police Immunization of Criminals}

The conferring of immunity upon an offender is an inevitable consequence of applying the exclusionary rule to any evidence that is essential to the prosecution. The cost of freeing the guilty has already been discussed. ${ }^{245}$ But there is an additional negative effect in the manner in which they are freed, in the dangerous power this vests in the police. The exclusionary rule permits police to immunize a criminal from prosecution by deliberately overstepping legal bounds in obtaining vital evidence. In the leading opinion rejecting the exclusionary rule for the state of New York (holding that it should not be imposed upon society without legislative action), Ghief Judge Cardozo identified this danger of the rule:

The pettiest peace officer would have it in his power, through overzeal or indiscretion, to confer immunity upon an offender for crimes the most flagitious. ${ }^{246}$

The "indiscretion" that confers immunity may be an act that conforms to a norm of police behavior for which the suppression of evidence is a known but not a desired consequence, such as an improper search to get a weapon out of circulation. But it may also be a deliberate overstepping of legal bounds in obtaining vital evidence for the express purpose of conferring immunity from prosecution. Such a result may or may not conform to a norm of police behavior. Some police are said to make bad arrests purposely in many juvenile cases to assure that the juvenile cannot be found guilty and subjected to a harsh

243 McMann v. Richardson, $90 \mathrm{~S}$. Ct. 678 (1970). For a discussion of the rule that a guilty plea is a waiver of a claim of unreasonable search and seizure, see Annot., 20 A.L.R.3d 724 (1968).

244 Alschuler suggests that plea bargaining seriously dilutes the deterrent effect of the exclusionary rule. See also text accompanying note 164 supra. In this manner, plea bargaining may have more influence on the exclusionary rule than the rule has on plea bargaining.

245 See text following note 212 supra.

246 People v. De Fore, 242 N.Y. 13, 23, 150 N.E. 585, 588 (1926). Wigmore found this argument "unpersuasive." WIGMORE, supra note 213 , § 2184, at 52 n.43. 
penalty. Other less benign possibilities are contrary to police norms, and raise ugly issues of corruption. ${ }^{247}$ Samuel Dash considered that the high proportion of defendants being released after granting of a motion to suppress in gambling cases in Chicago in 1950 was due to "corruption." After observing the routine of motion to suppress, testimony, and release, which involved the same police and the same events day after day, Dash concluded that "the raids are made to immunize the gamblers while at the same time satisfying the public that gamblers are being harassed by the police." 248

Empirical Research. It is possible to approximate the total cost of conferring immunity upon offenders due to the application of the exclusionary rule. Earlier discussion of the extent to which the motion to suppress is dispositive is addressed to that question. ${ }^{249}$ It is more difficult to measure the portion of that immunity that is conferred deliberately, and, because the triggering behavior is illegal, it is still more difficult to measure the smaller fraction that is conferred deliberately and corruptly. Though offending officers will be evasive, police department officials should be willing to cooperate because this type of conduct probably violates police norms as well as legal rules. The inquiry might proceed by a statistical grouping of all motions to suppress in various types of crimes, further subdivided by the various officers who made the arrest and seizure. If some officers had noticeably higher proportions of suppression of their evidence in a particular crime, or for a particular defendant, this could be indicative of either carelessness or corruption. But the evidence is not conclusive. There is no apparent method by which the extent of this type of misbehavior could be measured so long as it does not rise to the flagrant degree Dash observed in the gambling cases.

\section{F. Police Imposition of Extra-Judicial Punishment}

Earlier discussion cited doubts that the exclusionary rule could discourage police from arrests or seizures that were intended as extrajudicial punishments. ${ }^{250}$ This section concerns the related negative effect which suggests that the exclusion of evidence obtained by im-

247 The author spoke with one high police official who routinely examines all court reports where evidence is suppressed in order to initiate further investigation where an officer's testimony results in suppression of evidence with unusual frequency, especially in cases where particular defense attorneys are involved.

248 Dash, Cracks in the Foundation of Criminal Justice, 46 ILL. L. REv. 385, 391-2 (1951). The same subject is referred to in the same way by the Operating Director of the Chicago Crime Commission in Peterson, Restrictions in the Law of Search and Seizure, 52 Nw. U.L. REv. 46, 58 (1957). The proportion of release was about $76 \%$ in 1950 , and it is about $45 \%$ today. See Tables $4 \& 5$ supra.

249 See text accompanying note 234 supra.

250 See text following note 157 supra. 
proper means may actually encourage such misconduct by the police. ${ }^{251}$ Monrad Paulsen made this point:

Most disturbing is the argument that if the police are subject to the restrictions of the exclusionary rule they cannot obtain the convictions necessary to carry out their law enforcement function, and if they cannot obtain such convictions they will be tempted to harass suspects, to inflict extra-legal punishments. "The exclusionary rule," wrote Professor Waite, "has driven the police to methods less desirable than those for which the judges shut truth from the jury's ears."252

Joseph Goldstein has described a deliberate program of police harassment for the purpose of controlling gambling. ${ }^{253}$ Suspects are searched without legal grounds and if gambling paraphernalia is found they are arrested and the police confiscate the contraband and money (and the defendant's car, if it was involved) without any intention of applying the criminal law. The suspect is promptly freed by legal process. No prosecution ensues since the search was illegal, but the confiscated property is retained. A prosecutor explained this procedure by stating that "the police department [is] forced to find other means of punishing, harassing and generally making life uneasy for gamblers" because of the light penalties imposed on gambling offenses and the stringent requirements of the search and seizure laws. ${ }^{254}$ Frank W. Miller's American Bar Foundation study of prosecution practices in Kansas, Michigan and Wisconsin also observed the prevalence of confiscation as a remedy to compensate for the stringency of the search and seizure laws. ${ }^{255}$ Other investigators have noted the use of harassment as a technique of attacking prostitution, gambling and illegal liquor sales, ${ }^{256}$ crimes where convictions are frequently prevented by the exclusionary rule.

The Columbia study stated that preventive patrol, which consists of aggressive stop, search and confiscation practices, "seems to have

251 This is of course the converse of the common argument that if courts used illegally obtained evidence this would foster police misconduct.

252 Paulsen, supra note 58, at 257, quoting Waite, Judges and the Crime Burden, 54 Mrch. L. REv. 169, 196 (1955). Elsewhere Professor Waite has urged that the exclusionary rule "has in practical application conduced to serious police misbehavior. If it did not actually beget the 'tip-over raid, it nurtured that vicious practice to its evil florescence." Waite, supra note 27 , at 685 .

253 Goldstein, supra note 72 , at 580-4.

254 Id. at 584.

255 F. Miller, supra note 78, at 248.

250 TASK Force RePORT: The Police at 187, quoting LAFAve, supra note 34, at 456, 473, 478; Note, Philadelphia Police Practice and the Law of Arrest, 100 U. PA. L. REv. 1182, 1196-1200 (1952). 
grown recently as a means of avoiding the frustration of following Mapp,"257 but it tendered no data on the subject. It is unlikely that the exclusionary rule will directly deter the practice of preventive patrol since this tactic is, by definition, undertaken without the intention that it lead to prosecution. Whether preventive patrol is actually encouraged by the exclusionary rule is another question. Finally, Alan M. Dershowitz has suggested that by preventing a criminal prosecution the exclusionary rule may encourage the use of sexual psychopath laws or other "prediction-prevention" commitment alternatives. ${ }^{258}$

The exclusionary rule may also encourage a type of unintentional illegality. Edward L. Barrett, Jr. has suggested that the exclusionary rule may place pressure on the police "to make arrests earlier in the investigative process than they might otherwise simply to insure that the evidence secured, [since it is obtained by a search incident to arrest] will ultimately be usable at the trial." 259

Empirical Research. The extent to which the exclusionary rule actually fosters police illegality probably cannot be measured by objective criteria, although observation of police organizations might yield relevant impressions on the subject. The difficulty is the familiar problem of identifying the responsible cause or causes for an observed change. For example, an increase in police harassment or preventive patrol after adoption of the exclusionary rule would not in itself confirm the argument since such a change in law enforcement methods could be caused by many other factors. An additional difficulty is determining what changes have been made in police methods, especially after passage of almost a decade since the Mapp opinion. Where police conduct has resulted in written arrest reports, a comparative examination is still possible, as the Columbia study shows. But with practices like preventive patrol, which would not normally be recorded in written documents, there is probably no written evidence upon which a before-after comparison can be made. Police recollections unsubstantiated by written memoranda would not be sufficiently reliable.

257 Comment, supra note 83, at 100. Preventive patrol is described in note 160 supra. 258 Observation during Roundtable Meeting of Association of American Law Schools in San Francisco, December 28, 1969. See generally Dershowitz, Psychiatry in the Legal Process: "A Knife that Cuts Both Ways," 51 Judicature 370 (1968); J. Katz, J. Goldstein \& A. Dershowitz, Psychoanalysis, Psychiatry and Law 540-4 (1967).

259 Barrett, supra note 155, at 66 . Any such tendency should be reduced by the decision approving the admissibility of evidence obtained by an appropriate "stop and frisk." Terry v. Ohio, 392 U.S. I (1968). 
G. Forestalling the Development of Alternative Remedies

The exclusionary rule cannot be replaced as long as it remains a constitutional requirement. However, there is no legal obstacle to supplementing the exclusionary rule, especially in areas where it is admittedly ineffective. ${ }^{260}$ The obstacle is a practical one. The enormous concentration and reliance upon the exclusionary rule may forestall the development of alternative mechanisms for controlling improper behavior by the police. By a peculiar form of federal preemption, the Mapp decision may sap state officials' energy and determination to control law enforcement officials in alternative ways that might prove just as effective and even more comprehensive than the exclusionary rule. Thus, the President's Crime Commission Task Force Report on the Police observed that the police administrator is ambivalent about the degree of his responsibility for controlling improper law enforcement behavior by his personnel:

$[\mathrm{H}]$ e often sees the methods by which the law is enforced as involving matters which are the primary responsibility of others outside the police establishment. This deference may, in part, be attributable to the sharing of responsibilities with other agencies-particularly the courts. Unlike internal matters over which the police administrator has complete control, much of what the police do relating to crime and criminals is dependent for approval upon the decisions of nonpolice agencies. ${ }^{261}$

The report concludes that if the police are to develop a sense of responsibility in this area, they must be included in the important policymaking decisions, such as those regarding the revision of substantive and procedural laws, so that the final result will have a professional identification to which they can loyally conform.

Empirical Research. This point probably cannot be demonstrated by empirical evidence. A debater's answer is that the states had an opportunity to develop such alternatives between Wolf and Mapp, that they did not do so, and that there is no reason to expect greater creativity or impetus today.

260 Alfred Hill has recently urged that the Supreme Court preserve latitude for other courts or legislatures to develop alternative remedies that might prove to be adequate substitutes for the exclusionary rule. Hill, supra note 25, at 182-5. Of similar effect is Chief Justice Burger's criticism of the exclusionary rule, coupled with his advocacy of police discipline by "a commission or board which is predominantly civilian and external rather than an internal police agency." Burger, supra note 56, at 16. An alternative tort remedy is discussed in text following note 143 supra.

261 TASK FORCE REPORT: THE POLICE at 29. 


\section{H. Handcuffing the Police}

Much of the law enforcement community's opposition to the exclusionary rule has been expressed in terms of the vivid metaphor alleging that the rule "handcuffs" the police in the enforcement of the criminal law. ${ }^{262}$ In substance this familar argument is a protest against the underlying constitutional and statutory rights. More often than not, Yale Kamisar observes,

$[W]$ hat they are really bristling about is tighter enforcement of long standing restrictions. Thus, many in law enforcement reacted to the adoption of the exclusionary rule as if the guarantees against unreasonable search and seizure had just been written! ${ }^{263}$

The whole argument about the exclusionary rule "handcuffing" the police should be abandoned. If this is a negative effect, then it is an effect of the constitutional rules, not an effect of the exclusionary rule as the means chosen for their enforcement. Police officials and prosecutors should stop claiming that the exclusionary rule prevents effective law enforcement. In doing so they attribute far greater effect to the exclusionary rule than the evidence warrants, and they are also in the untenable position of urging that the sanction be abolished so that they can continue to violate the rules with impunity. If the constitutional rules concerning arrest and search and seizure really prevent effective law enforcement, then law enforcement officers should demonstrate that fact and forthrightly attempt to have those rules changed by appropriate authority.

\section{POSTSCRIPT}

Where the exclusionary rule is concerned, judges and scholars have explained their decisions by asserting the deterrent effect of the rule,

262 See generally Kamisar, supra note 79.

263 Id. at 440 . See also text accompanying note 215 supra. Unlike most prosecutors or police, Arlen Specter is quite candid in his objection to the rule: "In brief, the advantage of greater latitude for policemen in apprehending offenders outweighs the value of marginal protection of civil liberties. It is more important to convict the guilty than to prevent the unconstitutional search and seizure of the innocent which is only unpleasant .... There can be no doubt that the Mapp decision has significantly impaired the ability of the police to secure evidence to convict the guilty. How detrimental this has been, however, is a matter of opinion rather than demonstrable fact." Specter, supra note 28, at 41-42. In protesting the way in which the Mapp decision has "significantly impaired the ability of the police to secure evidence to convict the guilty" Specter is conceding that prior to the Mapp case the police violated constitutional rights with impunity, and that after the $M a p p$ case they were deterred from doing so. The first admission is damaging. The second is doubtful. 
and then have supported that effect by recourse to polemic, rhetoric, and intuition. If those are the acknowledged techniques in an evaluation of the exclusionary rule, then it should not be surprising if this article ends by recording the author's own polemic on the rule. A prior section concluded with a summary of the inferences that can fairly be drawn from presently available evidence on the deterrent effect of the exclusionary rule. ${ }^{264}$ The last two sections cited some additional evidence of possible limitations and negative effects of the exclusionary rule. This postscript draws upon that evidence, but it brushes past the uncertainties identified in the discussion of the data and makes some assertions that are not fully supported by it. What follows is an argument, not a conclusion.

The exclusionary rule should be abolished, but not quite yet.

As a device for directly deterring illegal searches and seizures by the police, the exclusionary rule is a failure. There is no reason to expect the rule to have any direct effect on the overwhelming majority of police conduct that is not meant to result in prosecutions, and there is hardly any evidence that the rule exerts any deterrent effect on the small fraction of law enforcement activity that is aimed at prosecution. What is known about the deterrent effect of sanctions suggests that the exclusionary rule operates under conditions that are extremely unfavorable for deterring the police. The harshest criticism of the rule is that it is ineffective. It is the sole means of enforcing the essential guarantees of freedom from unreasonable arrests and searches and seizures by law enforcement officers, and it is a failure in that vital task.

The use of the exclusionary rule imposes excessive costs on the criminal justice system. It provides no recompense for the innocent and it frees the guilty. It creates the occasion and incentive for largescale lying by law enforcement officers. It diverts the focus of the criminal prosecution from the guilt or innocence of the defendant to a trial of the police. Only a system with limitless patience with irrationality could tolerate the fact that where there has been one wrong, the defendant's, he will be punished, but where there have been two wrongs, the defendant's and the officer's, both will go free. This would not be an excessive cost for an effective remedy against police misconduct, but it is a prohibitive price to pay for an illusory one. As the present Chief Justice has written:

Perhaps we can all agree on two basic aims: first, that deterring official misconduct in law enforcement is a vital objective for 
society; and second, that society and the administration of justice are best served by vastly reducing, and if possible eliminating, the need to exclude relevant and probative evidence from a criminal trial whose very truth-seeking function is necessarily stultified to some degree by such exclusion. ${ }^{265}$

Despite these weaknesses and disadvantages, the exclusionary rule should not be abolished until there is something to take its place and perform its two essential functions. If constitutional rights are to be anything more than pious pronouncements, then some measurable consequence must be attached to their violation. It would be intolerable if the guarantee against unreasonable search and seizure could be violated without practical consequence. It is likewise imperative to have a practical procedure by which courts can review alleged violations of constitutional rights and articulate the meaning of those rights. The advantage of the exclusionary rule - entirely apart from any direct deterrent effect-is that it provides an occasion for judicial review, and it gives credibility to the constitutional guarantees. By demonstrating that society will attach serious consequences to the violation of constitutional rights, the exclusionary rule invokes and magnifies the moral and educative force of the law. Over the long term this may integrate some fourth amendment ideals into the value system or norms of behavior of law enforcement agencies. ${ }^{266}$

The opinion in Mapp $v$. Ohio properly relied on these advantages. ${ }^{267}$ But Mapp mistakenly assumed that the exclusionary rule was the only way to give judicial review and to grant credibility to the constitutional right. In fact, the exclusionary rule is a poor vehicle to accomplish either objective. Most people whose constitutional rights are invaded are not prosecuted. Others who are prosecuted plead guilty without having their claim adjudicated. The exclusionary rule provides no judicial review and no reinforcement of fourth amendment values for either of these large groups.

As to search and seizure violations, the exclusionary rule should be replaced by an effective tort remedy against the offending officer or his employer. Some of the law reforms necessary to make such a remedy

265 Burger, supra note 56, at 10.

266 See generally Kamisar, supra note 79, at 442-4; W. LAFAvE, supra note 34, at 504-5.

267 Mapp v. Ohio, 367 U.S. 643, 655 (1961) (without the exclusionary rule "the assurance against unreasonable federal searches and seizures would be 'a form of words,' valueless and undeserving of mention in a perpetual charter of inestimable human liberties, so too, without that rule the freedom from state invasions of privacy would be so ephemeral ... a as not to merit this Court's high regard as a freedom 'implicit in the concept of ordered liberty" "). 
effective were discussed earlier. ${ }^{268} \mathrm{~A}$ practical tort remedy would give courts an occasion to rule on the content of constitutional rights (the Canadian example shows how ${ }^{269}$ ), and it would provide the real consequence needed to give credibility to the guarantee. A tort remedy could break free of the narrow compass of the exclusionary rule, and provide a viable remedy with attendant direct deterrent effect upon the police whether the injured party was prosecuted or not. Such an arrangement is long overdue. It is time to have a comprehensive judicial remedy against all illegal arrests and searches and seizures by the police. And it is time to abandon the irrational and costly procedure by which police behavior is reviewed only when the injured party is prosecuted, and the only compensation for injury effectively puts both guilty parties beyond the reach of the law. 